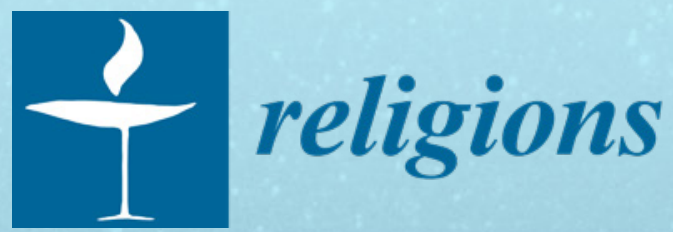

\title{
Faith after the
}

\section{Anthropocene}


Faith after the Anthropocene 



\section{Faith after the Anthropocene}

Editors

Matthew Wickman

Jacob Sherman

MDPI • Basel $\bullet$ Beijing $\bullet$ Wuhan $\bullet$ Barcelona $\bullet$ Belgrade $\bullet$ Manchester $\bullet$ Tokyo $\bullet$ Cluj $\bullet$ Tianjin 
Editors

$\begin{array}{ll}\text { Matthew Wickman } & \text { Jacob Sherman } \\ \text { BYU Humanities Center } & \text { California Institute of Integral Studies } \\ \text { USA } & \text { USA }\end{array}$

Editorial Office

MDPI

St. Alban-Anlage 66

4052 Basel, Switzerland

This is a reprint of articles from the Special Issue published online in the open access journal Religions (ISSN 2077-1444) (available at: https://www.mdpi.com/journal/religions/special_issues/ Faith_Anthropocene).

For citation purposes, cite each article independently as indicated on the article page online and as indicated below:

LastName, A.A.; LastName, B.B.; LastName, C.C. Article Title. Journal Name Year, Article Number, Page Range.

ISBN 978-3-03943-012-3 (Hbk)

ISBN 978-3-03943-013-0 (PDF)

Cover image courtesy of Andrew Seaman.

(C) 2020 by the authors. Articles in this book are Open Access and distributed under the Creative Commons Attribution (CC BY) license, which allows users to download, copy and build upon published articles, as long as the author and publisher are properly credited, which ensures maximum dissemination and a wider impact of our publications.

The book as a whole is distributed by MDPI under the terms and conditions of the Creative Commons license CC BY-NC-ND. 


\section{Contents}

About the Editors $\ldots \ldots \ldots \ldots \ldots \ldots \ldots \ldots \ldots \ldots \ldots \ldots \ldots$

Matthew Wickman and Jacob Sherman

Introduction: Faith after the Anthropocene

Reprinted from: Religions 2020, 11, 378, doi:10.3390/rel11080378 . . . . . . . . . . . . . 1

Lisa Dahill

Eating and Being Eaten: Interspecies Vulnerability as Eucharist

Reprinted from: Religions 2020, 11, 204, doi:10.3390/rel11040204

\section{Mary Frohlich}

The Vulnerable (Post) Modern Self and the "Greening" of Spiritual Personhood through Life in the Spirit

Reprinted from: Religions 2020, 11, 194, doi:10.3390/rel11040194 . . . . . . . . . . . . . . 19

\section{John Gatta}

The Saving Grace of America's Green Jeremiad

Reprinted from: Religions 2020, 11, 172, doi:10.3390/rel11040172 . . . . . . . . . . . . . 31

Whitney A. Bauman

Returning Faith to Knowledge: Earthlings after the Anthropocene

Reprinted from: Religions 2020, 11, 169, doi:10.3390/rel11040169

\section{George B. Handley}

What Else Is New?: Toward a Postcolonial Christian Theology for the Anthropocene

Reprinted from: Religions 2020, 11, 225, doi:10.3390/rel11050225 . . . . . . . . . . . . . . 53

Jacob Holsinger Sherman

Reading the Book of Nature after Nature

Reprinted from: Religions 2020, 11, 205, doi:10.3390/rel11040205 . . . . . . . . . . . . . 65

Timothy Robinson

Reimagining Christian Hope(lessness) in the Anthropocene

Reprinted from: Religions 2020, 11, 192, doi:10.3390/rel11040192 . . . . . . . . . . . . . . 77

Lisa H. Sideris

Grave Reminders: Grief and Vulnerability in the Anthropocene ${ }^{\dagger}$

Reprinted from: Religions 2020, 11, 293, doi:10.3390/rel11060293

\section{Willis Jenkins}

Sacred Places and Planetary Stresses: Sanctuaries as Laboratories of Religious and Ecological Change

Reprinted from: Religions 2020, 11, 215, doi:10.3390/rel11050215 . . . . . . . . . . . . . 105 



\section{About the Editors}

Matthew Wickman is Professor of English and Founding Director of the BYU Humanities Center. He is the author of The Ruins of Experience: Scotland's "Romantick" Highlands and the Birth of the Modern Witness (U of Pennsylvania Press, 2007), Literature After Euclid: The Geometric Imagination in the Long Scottish Enlightenment (U of Pennsylvania Press, 2016), and numerous articles that span across various humanities disciplines. His current work explores the relationship between literature and spirituality, with particular emphasis on the multiple forms and expressions of experiences of ultimate value.

Jacob Sherman is Professor and Chair of the Philosophy and Religion Department at the California Institute of Integral Studies. He taught previously at King's College London and the University of Cambridge. In addition to numerous articles and essays in philosophy, theology, and religious studies, he is the author of Partakers of the Divine: Contemplation and the Practice of Philosophy (Fortress Press, 2014), and editor, with Jorge Ferrer, of The Participatory Turn: Spirituality, Mysticism, Religious Studies (SUNY Press, 2007). He is currently working on a new manuscript addressing the theological, philosophical, and ecological aspects of 'The Book of Nature'. 



\title{
Editorial
}

\section{Introduction: Faith after the Anthropocene}

\author{
Matthew Wickman ${ }^{1, *}$ and Jacob Sherman ${ }^{2}$ \\ 1 English Department, Brigham Young University, Provo, UT 84602, USA \\ 2 Philosophy and Religion Department, California Institute of Integral Studies, San Francisco, CA 94103, USA; \\ jsherman@ciis.edu \\ * Correspondence: Matthew_Wickman@byu.edu
}

Received: 7 July 2020; Accepted: 20 July 2020; Published: 23 July 2020

\begin{abstract}
This is the introductory essay to the Special Issue "Faith after the Anthropocene" published in Religions 11:4 and 11:5. How does the Earth's precarious state reveal our own? How does this vulnerable condition prompt new ways of thinking and being? The essays that are part of this collection consider how the transformative thinking demanded by our vulnerability inspires us to reconceive our place in the cosmos, alongside each other and, potentially, before God. Who are we "after" (the concept of) the Anthropocene? What forms of thought and structures of feeling might attend us in this state? How might we determine our values and to what do we orient our hopes? Faith, a conceptual apparatus for engaging the unseen, helps us weigh the implications of this massive, but in some ways mysterious, force on the lives we lead; faith helps us visualize what it means to exist in this new and still emergent reality.
\end{abstract}

Keywords: Anthropocene; ecocriticism; faith; vulnerability; environment

The articles in this Special Issue began as invited papers at the Brigham Young University (BYU) Humanities Center symposium "On Being Vulnerable, Part II: Faith after the Anthropocene," held at Brigham Young University, Utah, in September 2019. This meeting was the logical, more thematically capacious and ethically urgent, follow-up to the symposium sponsored by the BYU Humanities Center the previous year, titled "On Being Vulnerable: 'Crisis' and Transformation." During that first meeting, a number of speakers reflected together on how retrenchment has become a dominant reflex of the humanities during vulnerable times, exacerbating the feeling of crisis from which the impulse toward defensiveness is designed to protect us. When we and our disciplines are rendered vulnerable, how do we respond? In addressing this question we took a cue from Hannah Arendt, who argues in The Human Condition that only actions of the most vulnerable kind-self-disclosing, interpersonal, and unanticipated; lacking defense of precedent or certainty of outcome-achieve lasting effects. ${ }^{1}$ Arendt associates such actions with speech and writing, drama, music-in short, with the arts and humanities - and contrasts them with displays of strength that fortify institutions and bolster economies but ultimately do little to cultivate the human spirit. In effect, she provides a model for the humanities after an era of "crisis," when humanities disciplines are increasingly portrayed as indefensible and when their greatest chance for survival, ironically, may depend on how their proponents embrace that very trait.

The symposium from which this Special Issue was born represented an amplification of this theme, addressing the vulnerability associated with our ecological condition. Our focus, however, was less the vulnerability of the Earth, per se, than how the Earth's precarious state reveals our own-how it prompts us to new ways of thinking and being. The Anthropocene, of course, designates the Earth in

1 See (Arendt 1958). 
a state of transformation, cataclysmically so, in response to human activity. However, is it possible, we asked, to imagine ourselves transformed for the better as a function of the ecological peril our planet faces? How might our consciousness of gathering catastrophe incite changes in us that help us redress the deeper conditions of which the Anthropocene is a symptom? We were especially compelled by the thought of how our vulnerable condition, ecologically and existentially, inciting the transformative thinking this condition requires, inspires us to reconceive our place in the cosmos, alongside each other and, potentially, before God. "Faith after the Anthropocene" refers to those ways that our current condition of sober novelty, of generative catastrophe, modifies our beliefs and practices, both religious and secular. Who are we "after" (the concept of) the Anthropocene? How might we project and approach the horizon of our existence? What forms of thought and structures of feeling might attend us in this state? How might we determine our values and to what do we orient our hopes?

However we answer those questions, it seems to us that faith plays a central role. We define faith, with Paul, as "the assurance of things hoped for, the conviction of things unseen" (Hebrews 11:1, NRSV). Such assurance typically pertains most directly to confessional religions, but Paul's definition relates, in some ways, to climate as well. Unlike weather, climate is notoriously difficult to perceive directly. It is experienced by everyone and no one; we can measure it and point to its effects, but we do not experience it the way we would an object. We only compound this challenge when we move, from climate per se, to an entire climatological epoch. Paraphrasing the Gospel of John, no one has seen the Anthropocene at any time. ${ }^{2}$ The Anthropocene, rather, is a name we accord a modern state of planetary being. Faith, a conceptual apparatus for engaging the unseen (even if, in this case, not "hoped for"), helps us weigh the implications of this massive, but in some ways mysterious, force on the lives we lead; faith helps us visualize what it means to exist in this new and still emergent reality. What is more, there is a practicality to faith, a translation of belief into action. In the words of a nineteenth-century theological treatise, "Would you have ever sown if you had not believed that you would reap? Would you have ever planted if you had not believed that you would gather? ... [W] hat have you, or what do you possess, which you have not obtained by reason of your faith? Your food, your raiment, your lodgings, are they not all by reason of your faith?"3 In the Anthropocenic Age, when "reap[ing] and "gather[ing]" become increasingly uncertain, our planet becomes a product of and a challenge to the kind of faith we invest in the future, the nature of the choices we make. We recreate it, we hope, through our collective actions.

The scope of the Anthropocene is essentially planetary. Whatever else it means, it refers to the enormous influence of human beings upon the entire terrestrial system, and thus the historical emergence of the anthropos as a geological agent. While the effects of the new climatic regime are certainly global, the faiths upon which we focus in this Issue are necessarily more regional. We focus especially on certain western expressions of Christian faith, including its transformation or disappearance, both aspects of its vulnerability. This Issue, in other words, is focused on the way that communities and intellectual traditions shaped by the Christian legacy are responding in a variety of theoretical and practical ways to the new conditions of universalized precarity brought on by the Anthropocene. We acknowledge, of course, that global and interreligious perspectives are urgently needed, but we also believe that these are best realized when they engage with rich, local conversations rooted in particular histories, traditions, and cultures. By doing some of that more local scholarly spadework we hope that the contributions in this Special Issue may, in their own granular ways, help to prepare the ground for some of those larger, more global conversations in the future.

In thinking together about the faith in the Anthropocene, we are continuing a scholarly conversation about the complex role of Christianity and the cultures it has influenced in generating and responding to widespread ecological challenges. While Christian traditions have a long and venerable history of

\footnotetext{
"No man hath seen God at any time..." (John 1:18, KJV).

(Smith [1876] 2010).
} 
thinking about both nature and creation-the Hebrew prophets, for example, thought passionately about issues of environmental degradation-Christian involvement in the coordinated efforts of ecological theory and action only emerged in the twentieth century in response to the new science of ecology, on the one hand, and to the novel moral visions articulated in conservation and environmental movements, on the other. Although broad Christian engagement with ecological theory and action is perforce a relatively recent phenomenon, it is now a substantial, growing, and promising area of contemporary study, including emerging specialties such as ecotheology and emerging fields such as Religion and Ecology. Throughout the last decades of the twentieth century, this initial Christian engagement with ecological concerns was often somewhat reactive and tended to deploy two strategies: one characterized by an attempt to make Christianity "green", either by revising inherited beliefs and practices in accord with present ecological considerations, the other by the attempt to show how Christian scriptures and traditions, in their most authentic guises, were already substantively ecological. This late twentieth-century approach to ecotheology often took for granted that the central ethical and theological question with regard to ecology was anthropocentrism and its alternatives (usually some form of either biocentrism or ecocentrism). There is still much that is valuable in this literature, but our Issue locates itself more in the recent work both by Christians and by those of other traditions that has tended to shift the conversation away from the demands of a kind of ecological a priori (non-anthropocentrism) before which religious traditions need to justify themselves, and towards a more dialogical, theoretically rigorous, and heuristic exploration of the way religious communities might deploy their spiritual and intellectual traditions in order to participate in the continuing effort to construct an integral ecological theory, practice, and politics able to meet the demands of a warming world and a vulnerable creation.

Of course, ecologies rooted in Christian traditions have struck up rich conversations with other bodies of religious thought and practice-something this Issue models in the essays by Whitney Bauman, Willis Jenkins, and Lisa Sideris. While deeply attuned to the questions that have animated philosophies of "faith", Bauman, Jenkins, and Sideris take up different aspects of these questions that bear less directly on Christianity. All of the contributions to this Issue are rich and varied, however, and some introduction to them is in order.

Lisa Dahill explores the relationship between ecology and traditional Christian ritual and beliefs, analyzing the sacraments and the theology of the resurrection as forms through which to ponder our need for the "wild." The latter represents aspects of nature that deeply inform our ecological being but that we typically repress and from which we are easily estranged. Dahill is especially taken with thoughts of the Eucharist and ways we become food, and thus sustain life, for other creatures, whether predators or simply microorganisms after our bodies begin to decompose. Mary Frohlich also pushes us to consider our wider network of attachments, though for her "greening the self" means putting individuals into a wider network of relations that includes God and the cosmos. How we enter into communion with these agencies beyond ourselves depends, in large measure, on how we are able to adapt to what she calls the "rhythms of the Spirit," the ecological motions of the divine that inform all life. John Gatta, meanwhile, turns our attention to another shade of "green," the "Green Jeremiad." The use of this rhetorical form in America dates back to the "city on a hill" sermons that took root with the Puritans. It finds new life in powerful rhetorical interventions by Rachel Carson, Bill McKibben, Barbara Kingsolver, and others, serving as an ecological great awakening to our responsibilities in the Anthropocenic age.

However, is the language of the Anthropocene even the best way for us to bring attention to the urgent realities of the present day? Whitney Bauman raises some important doubts. As he sees it, the term only perpetuates longstanding, destructive projections of humankind onto nature, making the remedy symptomatic of the traditional problem. What is more, the type of human we find projected onto nature, still, tends to be hegemonic and heteronormative, recapitulating racial, gendered, and sexual hierarchies that elsewhere, in social domains, are frequently subjected to thoroughgoing criticism. Bauman wonders whether a range of different-planetary-ways of framing our current dilemma 
would not yield a more diverse, truly ecological way to address the precarities of our current condition. George Handley's argument similarly takes up problems with Anthropocenic discourse, although he situates the solution more squarely on religious grounds. How does an enhanced understanding of the fall and the atonement enable us to perceive- to read-nature more fully? How might it help us better understand the limits and possibilities of human agency? In short, how might we cultivate a more resilient Christian theology of nature?

This is made all the more complicated by the fact that the very concept of nature-a concept that often turns on the notion of an unsustainable and ecologically invidious nature/culture duality-is increasingly contested by philosophers, critical theorists, and environmentalists alike. Do we need to disabuse ourselves of the very concept of nature in order to move toward a greater vision of ecological flourishing, as many now suggest? In his essay, Jacob Sherman argues that while the modernist notion of nature as the stable backdrop for the adventures of human history, culture, and epistemic achievement is indeed problematic, premodern approaches to the "book of nature" such as one finds in the twelfth-century work of Hugh of Saint Victor may be more promising. Indeed, precisely because they subvert modernist categories of nature and culture, a creative retrieval and critical reimagining of such premodern theological and contemplative approaches to reading the book of nature may offer important resources for the postmodern task of crafting a "terrestrial" hermeneutics of nature in the midst of the Anthropocene. The task of reimagining Christian life in the Anthropocene is taken up, as well, by Timothy Robinson in his reconstruction of Christian hope in the face of profound vulnerability, ecological precarity, and a certain inescapable hopelessness. Christian hope has often been construed as a way to avoid our historical vulnerability by placing faith for the future in some unparalleled power: God's omnipotent providence and divine sovereignty for a certain kind of confession, but also hope in political action and movements, hope in technological innovation and human ingenuity. However, such appeals to be saved by a great power coming to us from outside cannot assuage the ecological anxiety so many suffer today. By contrast, Robinson commends a deeper hope, one that embraces a kind of virtuous hopelessness, and commends us to act with justice and wisdom on behalf of the Earth not for the sake of some outcome but as a good in itself. Hope, for Robinson, is not epistemic, but enactive.

In her essay, Lisa Sideris also attends to the way in which human comportment to the past and the future is brought to grief by the tremendous ongoing changes associated with the Anthropocene. The loss and devastation wrought by climate change and the great extinctions underway can give rise to immense grief and mourning. Responses to this environmental grief run from repression and denial by those seeking to preserve current human civilization at all costs to responses of creative mourning, remembrance, and the embrace of death and loss as integral to any meaningful change. Throughout her essay, Sideris attends as well to the way that moral, religious, and quasi-religious elements are profoundly apparent in the writings of secular authors as they confront environmental grief. Finally, Willis Jenkins also draws our attention to the way that categories of religion continue to operate even "outside" of those forms of life usually deemed religious. Drawing on fieldwork conducted in Bhutan and Yellowstone, Jenkins shows how processes of sacralization interact with ecological stresses as both human and non-human or environmental actors collaborate to make spaces sacred, to set them apart as sanctuaries from sovereign and exogenous powers, especially in response to sudden ecosocial changes. Jenkins' work highlights for us the transdisciplinary challenge of making sense of such complex collaborations of human and non-human actors in particular geographical places that are, nevertheless, affected by planetary developments and across both sudden and geological spans of time. It is not only faith that is transformed in the Anthropocene, but scholarship too, and new methods, collaborations, and vulnerabilities will be needed as we struggle to understand, to critically engage, and perhaps to hope. In such a spirit, we offer these essays to our readers not at all as the last word, but as a contribution to a conversation that we believe is ever more urgent.

Funding: This research received no external funding. 
Conflicts of Interest: The authors declare no conflict of interest.

\section{References}

Arendt, Hannah. 1958. The Human Condition. Chicago: University of Chicago Press, pp. 198-207.

Smith, Joseph, Jr. 2010. Lectures on Faith. Springville: Cedar Fort, Inc. First published 1876.

(C) 2020 by the authors. Licensee MDPI, Basel, Switzerland. This article is an open access article distributed under the terms and conditions of the Creative Commons Attribution (CC BY) license (http://creativecommons.org/licenses/by/4.0/). 

Article

\title{
Eating and Being Eaten: Interspecies Vulnerability as Eucharist
}

\author{
Lisa Dahill \\ Religion, College of Arts and Sciences, California Lutheran University, Thousand Oaks, CA 91360, USA; \\ ldahill@callutheran.edu
}

Received: 7 March 2020; Accepted: 14 April 2020; Published: 20 April 2020

\begin{abstract}
Living in a time of urgent ecological crisis, Christians need outdoor ritual experience of their faith: of what is wild, of the living Earth, stranger faces of the divine: taking eco-alienated people out of the building and into the streets, the river, the forest. Moving liturgy outdoors makes possible an opening to both human and more-than-human strangeness on their own terms, in actual, present, sensory experience. It also opens worshipers' experience of the Christian sacraments into the disconcerting realm of our bodies' physical edibility to other creatures: the possibility of our own flesh becoming food. Using the work of Val Plumwood, David Abram, and Eric Meyer, this paper examines Eucharistic ritual language and theologies of resurrection as these contribute to a worldview that maintains a human versus food dualism incommensurate with biological processes. Ultimately, the paper calls for Eucharistic practices that allow participants to pray being prey.
\end{abstract}

Keywords: predation; food; ecology; Eucharist; Earth; sacrament; ritual; resurrection; Plumwood; Abram

\section{Introduction: Being Eaten}

It is not a minor or inessential feature of our human existence that we are food: juicy, nourishing bodies.

Val Plumwood, "Meeting the Predator," in Eye of the Crocodile. 10.

For some time, I have been exploring the question of what happens when Christian liturgy moves outdoors, into engagement with the more-than-human natural world. Living in a time of urgent ecological crisis, Christians need outdoor ritual experience of their faith: of what is wild, of the living Earth, stranger faces of the divine: taking eco-alienated people out of the building and into the streets, the river, the forest. Moving liturgy outdoors makes possible an opening to both human and more-than-human strangeness on their own terms, in actual, present, sensory experience.

It also opens worshipers' experience of the Christian sacraments into the disconcerting realm of our bodies' physical edibility to other creatures: the possibility of our own flesh becoming food. Australian philosopher Val Plumwood is among those who have thought most deeply and broadly on the topic of human edibility, in the wake of her 1985 experience of a near-fatal crocodile attack. ${ }^{1}$ Somehow surviving three death-rolls before managing to break free and crawl miles to rescue, Plumwood experienced her normal perceptual world collapsing violently into the primal physicality of her body being taken as food for another animal. In subsequent years, she reflected deeply on the raw shock of that: how she, like most contemporary humans well buffered from the natural world, had unconsciously defined herself as transcending the risk of predation-we are those who eat but are never to be eaten-and how utterly that perception diverges from reality. Philosopher James Hatley uses Kristevian language

1 Her posthumously edited collection of essays, The Eye of the Crocodile (Plumwood 2012), presents this material powerfully. See also her 1999 essay "Being Prey" for a more detailed account of the crocodile attack itself, in The New Earth Reader: The Best of Terra Nova, edited by David Rothenberg and Marta Ulvaeus (Plumwood 1999, pp. 76-91). 
of the "uncanny goodness of being edible to bears": that same existential shock of realizing that other large predators encountered at an unlucky moment will happily take us for food. ${ }^{2}$ We are part of the food web, a fact most of us in our collective orientation to reality effectively screen from consciousness. The rest of the world is food; we are not.

Plumwood makes clear that this denial of being prey goes well beyond the natural urge to defend ourselves and our children from predation. She asserts that, in addition, we are collectively maintaining a sort of philosophical category error with regard to ourselves.

... there was something profoundly and incredibly wrong in what was happening, some sort of mistaken identity ... The creature was breaking the rules, was totally ... wrong to think I could be reduced to food. As a human being, I was so much more than food. It was a denial of, an insult to all I was to reduce me to [mere] food. ${ }^{3}$

Seeing herself in the crocodile's predatory gaze — and then its jaws—-forced her out of that delusion of categorical human inviolability into a reality that felt initially inconceivable:

I leapt through the eye of the crocodile into what seemed ... a parallel universe, one with completely different rules to the "normal universe." This harsh, unfamiliar territory was the Heraclitean universe where everything flows, where we live the other's death, die the other's life: the universe represented in the food chain. I was suddenly transformed in the parallel universe into the form of a small, edible animal whose death was of no more significance than that of a mouse...

It was because the world in which I was meat diverged so wildly from what I saw as reality that I could not recognize it as the world of my own everyday experience, and had to adopt the "parallel universe" fiction. But that was a measure of my delusion ... It has been a great struggle for me to recognize and reconcile with this harsh world as my own. ${ }^{4}$

Those who are Christian are increasingly facing our complicity in this long-standing delusion, in many places attempting to move beyond the anthropocentrism Lynn White and many others have observed in the tradition. Nevertheless, we have not yet awakened collectively to our profound vulnerability to and with all other creatures on Earth. The reforms needed to make possible the wide-scale shock of immersion in reality Plumwood experienced are complex and require attention on many levels. What would it take to invite us all out of our massive collective cosmological delusion and denial, and into reality? For Christians, I am convinced that a pivotal piece needed is change to the holiest rituals of our faith: specifically, the sacramental rites of baptism and Eucharist, the bodily experiences that most deeply crystallize, enact, and, in turn, nourish the Christian imagination and worldview.

For instance, in my 2016 essay, "Rewilding Christian Spirituality," I call for a return to the early church practice of baptizing in local waters, ending the sacred/profane symbolic dualism that enacts baptism into so-called "holy water," within a building considered "sacred space," in a special pool to which only humans are admitted, and from which these humans are considered to belong to a Body embraced into a paschal hope of glorious personal resurrection to eternal life. Returning the practice of baptism to the local creek, river, or ocean complexifies this theology considerably, both inviting and requiring the perception of this water as the holy water-demanding all the care and ethical political protection it truly deserves-and reconfiguring the meaning of baptism to center in literal immersion in this watershed, with the pollution and frogs, salmon and mosquitoes, and homeless encampments it

James Hatley, "The Uncanny Goodness of Being Edible to Bears" (Hatley 2004, pp. 13-31).

Val Plumwood, "Meeting the Predator" (Plumwood 2012, pp. 11-12).

(Plumwood 2012, pp. 13-14). 
actually contains (also, in the ocean, sharks—see, predation!): all of this somehow part of that body of Christ. $^{5}$ And we need Eucharistic immersion into our actual vulnerability as literal food to the rest of the world.

In this article, therefore, I first trace the ways much Eucharistic ritual language reinforces this implicit or explicit separation between humans and the rest of the animal, creaturely, and natural world-creating thereby, in addition to the God/world or human/animal distinctions many have noted, a core human versus food dualism as well. Next, I locate the heart of the problem for Christians in views of Jesus's death and resurrection that insist that Jesus retains human form forever in his risen body and brings believers with him into resurrection, thus religiously grounding the "we are not meant to be food" delusion. Third, I explore insights from Eric Meyer regarding humans as food to other creatures along with what I see as the limits of his proposal—namely its confinement within that view of resurrection I find problematic. Finally, I develop a theologically and biologically more adequate view of death and resurrection, toward a Eucharistic vision and ritual practices in touch with reality. This paper is part of a larger project more fully addressing these questions and their theological and anthropological implications, to be titled Jesus in the Earth; so, just a sketch here.

\section{Eucharist: Who Eats Whom?}

Ritual studies scholars have long explored how rituals make meaning, or help individuals and communities negotiate complex transitions, or create and sustain worldviews and social structures. ${ }^{6}$ That ritual is a key dimension of how a given religious tradition inculcates its core vision of reality is a basic assumption of this paper. Jesuit Juan Mateos opens the world-changing effect of such ritually charged perception:

During a feast we feel ourselves transferred to a different world. A skeptic will call this an illusion because the world goes on just the same and no ladders appear to bear us to the sky. Is it really an illusion? ... Those who feast live in a new world, which is their own seen through prophetic eyes; they go out to meet the good world created by God and for them it is brother and sister not enemy. ${ }^{7}$

And liturgical theologian Robert Hovda notes,

Good liturgical celebration, like a parable, takes us by the hair of our heads, lifts us momentarily out of the cesspool of injustice we call home, and puts us in the promised and challenging reign of God, where we are treated like we have never been treated anywhere else ... where we are bowed to and sprinkled and censed and kissed and embraced and where we share equally among all a holy food and drink. ${ }^{8}$

These quotes celebrate liturgy opening liberating new worldviews-but of course it can also reinforce our blind spots. The first thesis of this paper is that Eucharistic practices, precisely as

5 "Rewilding Christian Spirituality" (Dahill 2016d). This essay appeared in slightly amended form as "Into Local Waters: Rewilding the Study of Christian Spirituality" (Dahill 2016b).

6 Catherine Bell, Ritual: Perspectives and Dimensions (Bell 1997); from a Christian liturgical perspective, see Gordon Lathrop, Holy Things: A Liturgical Theology (Lathrop 1998). With regard to sacramental theology in particular, Benjamin Stewart has demonstrated how the form of baptismal experience-full immersion or sprinkling-shapes participants' spontaneous, untutored articulation of what their baptism means (Stewart 2009). In relation to Eucharist, several recent works explore how this ritual might more profoundly shape human ethical, political, social, and ecological practices. Cláudio Carvalhaes traces insights around Eucharist and relationships of various kinds in Eucharist and Globalization (Carvalhaes 2013); in The Eucharist (Bieler and Schottroff 2007), Andrea Bieler and Luise Schottroff probe connections between Eucharistic practice and human bodily suffering, including the experience of torture; Angel F. Mendéz Montoya explores the profound physicality of food and eating (though not being eaten) in relation to a range of cultural contexts in Theology of Food (Mendéz Montoya 2009); and Hugh O'Donnell has written a powerfully poetic immersion into ecological connections in Eucharist and the Living Earth, new and revised edition (O'Donnell 2012).

7 Juan Mateos, in A Sourcebook about Liturgy (Huck 1994, p. 3).

8 Robert Hovda, in A Sourcebook about Liturgy (Huck 1994, p. 1) 
powerful contributors to participants' conceptions of themselves and the world, can function to reinforce Christian convictions of human invulnerability to being eaten.

At first glance, this claim might seem counterintuitive, at least among worshipers of Catholic, Anglican, Lutheran, and Orthodox Eucharistic theology and piety who celebrate the physicality of the sacrament and Jesus's being eaten: his divine/human body and blood moving physically into one's own body, to become metabolized into one's own flesh, and pervading a fully sacramental cosmos. ${ }^{9}$ This devotional piety allows worshipers to worship and receive a physically vulnerable God who comes to feed body-selves, becoming knit into the very tissues and blood cells of worshipers. Here, the experience of Eucharistic physicality provides the courage to live ever more deeply into one's own physical vulnerability as the place of encounter with the divine. ${ }^{10}$ Martin Luther's 1527-28 Eucharistic debates with Ulrich Zwingli provide a locus classicus of the Lutheran insistence on and celebration of the raw physicality — even carnality—of the incarnation: the glory of God found not in some "pure" disembodied realm in heaven but precisely in human mouths, gullets, guts, and flesh. ${ }^{11}$ This insistence on flesh itself bearing Christ is a signal dimension of many eucharistic spiritualities, grounding an ethic often powerfully oriented to the ongoing health, feeding, and flourishing of real bodies around the world.

Yet for all its attention to bodies, and opening to the whole world sharing in sacramental beauty, even this highly incarnate Eucharistic piety does not generally attend to the full physical implications of the Eucharist-namely how worshipers' bodies become, in turn, food for other creatures. If the idea of God becoming food and feces was abhorrent to Zwingli, the idea of giving thanks for ticks or wolves or microbes or maggots eating us is equally unthinkable to climate-controlled, "pest"-destroying, corpse-encasing, resurrection-proclaiming Western Christians today. We don't go there-ever.

- For most Christians, Sunday by Sunday, the language and imagery of Eucharist describe an almost solely God-human reality. Nearly all the published Eucharistic prayers of the Catholic and Anglican churches, many of those of mainline traditions, and nearly all the communion language I've heard in my limited experience with nondenominational, evangelical, or other conservative churches, frame their thanksgiving around the story of human "salvation history" and believers' incorporation into the Body of Christ toward eternal life. ${ }^{12}$ At most, we might hear reference to the grains and grapes harvested to become the sacramental elements.

- In more creative mainline communities, including some renegade Anglicans and Catholics, other species do make their way into Eucharistic praying. Lions and lambs might peaceably attend an eschatological banquet at which there is no predation; and some communities now include reference to the Big Bang, or webs of life, or the soil, water, and farmworkers who bring us the grain and grapes. ${ }^{13}$ These are all salutary. Here too, however, pray-ers are located as eaters only,

9 See, e.g., Dorothy C. McDougall, The Cosmos as the Primary Sacrament (McDougall 2003); John Hart, Sacramental Commons (Hart 2006); Brian Douglas and Terence Lovat, "A Sacramental Universe" (Douglas and Lovat 2011).

10 The Eucharistic theologies cited in note 6 trace powerfully the interconnections between Eucharistic practices and human bodily experience of many kinds, including AIDS, torture, disability, illness, hunger, sexuality, joy, and kinship with the natural world. See also Emmanuel Falque, The Wedding Feast of the Lamb (Falque 2016).

11 Martin Luther, "That These Words of Christ, 'This Is My Body,' Still Stand Firm against the Fanatics," Luther's Works, edited by Robert H. Fischer. Vol. 37. (Luther 1961). A branch of philosophical hermeneutics centering in the body might be said to bring Luther's insistence on the materiality of God into new forms of nondualist thinking. See, e.g., Richard Kearney and Brian Treanor, Carnal Hermeneutics (Kearney and Treanor 2015). The emerging field of new materialist studies in religion similarly subverts classical God-world dualism, exploring the vibrancy or agency of matter itself; see Catherine Keller and Mary-Jane Rubenstein, eds., Entangled Worlds: Religion, Science, and the New Materialisms (Keller and Rubenstein 2017).

12 Eucharistic Prayers I, II, III, V, and VI in Evangelical Lutheran Worship (Augsburg Fortress 2006) fall into this category of more traditionally human-centered prayers, as do those of the Book of Common Prayer (Episcopal Church 1979) and The Roman Missal (United States Conference of Catholic Bishops 2010).

13 Eucharistic Prayers IV, VII, VIII, IX, and X in Evangelical Lutheran Worship (Augsburg Fortress 2006) display greater creationand human-justice orientation. See also the Eucharistic prayers of the Episcopal Church USA's Enriching Our Worship (Episcopal Church 1998, pp. 57-65). Gail Ramshaw is a primary poet of emerging Eucharistic prayers; see the twenty prayers gathered in Pray, Praise, and Give Thanks (Ramshaw 2017). 
not those being eaten; and the salvation depicted, which might now encompass explicitly the entire biosphere or universe, still rests on promises of resurrection that keep humans separate into an individually perduring eternal life. Most of these rituals' location inside church buildings powerfully reinforces the sense that those who are really included - those being fed and oriented to a God reliably present within these holy walls-are solely humans, namely us.

- In the wildest communities I know, those of the Wild Church Network, ${ }^{14}$ worshiping permanently outdoors blows open that architectural symbolic of physical human separation from the larger world for this holiest of rites. Wild Church communities come from many traditions, with practices as diverse as our bioregions, but all gather outdoors, from city streets or parks to so-called wilderness, inviting people to experience Christian or interreligious ritual practice out in the thick of it all. These communities often include the place and its creatures explicitly as part of the Eucharistic assembly, scattering bread and pouring out wine for all who live here and addressing, attending to, or including the more-than-human world in diverse ways. Nevertheless, even here surprisingly little if any attention occurs in the practice of Eucharist or communion to our being food. 15

I imagine that a handful of Wild Church leaders do play with this motif in their work-in fact, maybe they're so far off the grid that they missed my informal Facebook survey on this question. I imagine too that many in mainline, Catholic, and evangelical communities may be thinking along these lines, even if their community's ritual prayer may not reflect that. But these people are not the majority in any tradition, and it seems fair to conclude that, in practice, very few Christians are being regularly invited to consider deeply our raw physical vulnerability to other creatures-our being food-in Eucharist. When they come to worship, they find themselves in the human-centered gaze of a God who sees and feeds them, promising that they can remain human forever: an eternity of being a risen version of oneself. A vision where death doesn't mean losing one's form into full decomposition and diffuse re-embodiment into many other bodies upholds that fatal illusion that we will somehow avoid this ultimate vulnerability. ${ }^{16}$

Yet being eaten after death and metabolized into countless new tissues and lives—not rising to an eternal version of our present personhood-is a core biological reality of our lives. This prospect is not joyful for most, and Christians are happy to have the promise of an eternally human resurrection future instead, however vaguely that may be understood. But what if that resurrection vision is false? ${ }^{17}$ What if this attempt to withdraw our bodily availability from other creatures after death for heaven instead, denying our really and truly dying and becoming food, represents in fact the exact category

14 https://www.wildchurchnetwork.com/.

15 I draw this highly unscientific conclusion from responses to a question I posted to the Wild Church Network (WCN) Facebook page in September 2019. I received thoughtful, spirited responses from ten WCN leaders who found the question provocative and intriguing but noted they did not themselves pray in this way with their communities.

16 The green burial movement is a salutary development in the larger spiritual and physical reconciliation of humans with our ultimate earthly edibility. Some Eastern Christian burial texts also include language pointing to our being eaten after death. Benjamin Stewart has surfaced fascinating examples. For instance: "Come, enter in, and see how many heroes sleep here, and are made dust for the moth and the worms in the abyss of Sheol. Come, enter in, and see how the great spoils which death hath captured are made worthless dust in the pit of Sheol," in Douglas Webb, "The Funeral Services of the Nestorian Church" (Webb 1983, p. 298). In an email of 9 November 2019, Stewart wrote, "while it's not as obvious here, the word 'gaping' could recruit some of the metaphorical sense of 'mouth' ... and thus that the earth itself is imagined as consuming the dead body: 'O gaping earth, receive the body formed from you by the hand of God, again returning to you as to its mother. What has been made in his image, the Creator has already reclaimed. O Earth, receive this body as your own.' Here's an online source: https://prostopinijefiles.wordpress.com/2018/10/01/burying-the-departed/."

17 I am not treating here the perhaps even more widespread North American Christian assertion of a body/soul dualism after death, in which one might be perfectly happy to consign one's body to the worms, while viewing the immortal soul as the part of oneself that "ascends" to heaven. Rather, this paper engages the traditional Christian insistence on the body's participation too in eternal life, its credal assertion of the "resurrection of the body." I do not have space to engage theologies such as, e.g., (Carnley 2019), who affirms the risen body of Christ in or as the Eucharistic elements and the Christian community but whose Platonic reading of Paul and the tradition also upholds the flesh/spirit split my proposal is attempting to overcome. See his chapter, "The Resurrection of the Body," (Carnley 2019, pp. 242-67). 
error Plumwood names so powerfully? What if, Sunday after Sunday, even the most ecologically minded communities are unwittingly reinscribing this untruth on one another's psyches in ways that, across the global humanity Christians still dominate, contribute to the mass denial of our individual vulnerability to other creatures and thus, paradoxically, accelerate our species-wide vulnerability to extinction in the unsustainable alienation this denial has created? I challenge Christian communities to rethink the assumption that resurrection theology will miraculously defeat biology, and start exploring much more seriously and playfully how the core fact of our being food could pray—can we pray being prey?-constructively, in fact Eucharistically.

\section{What Kind of Resurrection?}

I am here moving into part two of my thesis: namely that the theology of the resurrection-Jesus's resurrection and believers' with him-is a central problem keeping the Christian tradition from being able to fully connect the Eucharistic dots. The sacramental enactment of Jesus's death and resurrection and believers' union with him is what primarily shields us ritually from facing our absolute participation in the meat economy of Earth. We are invited to experience ourselves as those destined for heaven instead. I see this problem in action dramatically in Eric Meyer's work.

Meyer's book Inner Animalities is a creative contribution on questions of predation, a topic central to his book exploring how the Christian tradition treats human animality. His is the only sustained work I know on what being food to other creatures has to do with Christian Eucharist, and he articulates a beautiful vision that centers in the reality of interspecies predation. ${ }^{18}$ Yet for all its originality, Meyer's vision is not ultimately convincing-precisely because his theological commitment to the resurrection obliges him to pull back from the full scope and implications of these questions.

Meyer centers his eschatological proposal in the Eucharistic faith claim that, despite being chewed and swallowed countless times every day over thousands of years in Eucharists going on ceaselessly around the world, Jesus is not thereby destroyed. He is endlessly eaten but never ceases to be fully intact and alive:

The resurrected wholeness of Christ's body is not contradicted by its endless consumption. ... The broken, betrayed, abandoned, and executed body of Jesus-a body preyed upon-is also a body whose flesh and blood continues to be consumed, even as Christ surely lives beyond suffering and death .... The eucharistic paradox in which Christ is consumed but not diminished offers a theological bridge across the problems of glorious consumption and predation. ${ }^{19}$

It's a brilliant idea: as with Jesus, the first fruits, so it will be in the ultimate resurrection of all things, eating and being eaten. Eternally, he posits, each species will still be eaten as they are on Earth, but without being destroyed, each endlessly persisting in its own reality despite being endlessly eaten, like Jesus. This eating will take place without hunger on the part of the predators-because in heaven there is "no need to incorporate energy from outside our bodies to survive," ergo no hunger-nor is there death, nor suffering for the prey. ${ }^{20}$ Yet if it's not the deepest gift and mercy to receive another creature's life, without which I will die-since in heaven there is only nonstop eternal life- then the logic of predation vanishes. That shuddering gratitude that comes only when you are very hungry indeed, and another animal or plant's self-gift infuses your body with its own literal cells as you moan

18 Eric Daryl Meyer, Inner Animalities: Theology and the End of the Human (Meyer 2018). Other work explores these questions with similar brilliance but without the connection to Eucharist. See Erika Murphy, "Devouring the Human: Digestion of a Corporeal Soteriology" (Murphy 2014); Denise Kimber Buell, "The Microbes and Pneuma that Therefore I Am" (Buell 2014); and Ernst Conradie, "To Eat or Be Eaten? That's the Question" (Conradie 2018).

19 (Meyer 2018, pp. 156-57)

20 (Meyer 2018, p. 160). 
to take it into yourself is why food is sacrament, is thanksgiving. ${ }^{21}$ Meyer's vision moves far out of synch with the actual ceaseless flow of life, what predation, food, hunger, and life on Earth really mean. The heart of the problem, what forces his predation-friendly bodily eschatological vision out of touch with biological reality, is Meyer's allegiance to the resurrection, his proposal's centering on a template (Jesus) of a body fixed forever in its singular earthly form, never dissolving kenotically into endless new wild lives. I question whether a Eucharistic vision clinging to Jesus's bodily human resurrection as its model can ever incorporate real predation, real eating, as these move into and through countless plant, animal, and mineral forms across countless generations of life.

Environmental ethicist Lisa Sideris has been insisting for some time on the necessary congruence between religion and biology, ${ }^{22}$ The latter work provides a caution against naively deifying science. and David Batchelder similarly calls for rituals and ritual practices that tell the truth. ${ }^{23}$ Phenomenologist and cultural ecologist David Abram is, however, perhaps the most thoroughgoing thinker I know in the depth and precision of his observations into the physical, sensory foundations of human perception and language. Regarding the intellectual process that gives rise to his writing, Abram notes:

It is a way of thinking that strives for rigor without forfeiting our animal kinship with the world around us - an attempt to think in accordance with the senses, to ponder and reflect without severing our sensorial bond with the owls and the wind. It is a style of thinking, then, that associates truth not with static fact, but with a quality of relationship. ${ }^{24}$

I too aspire to think "without forfeiting our animal kinship with the world around us," trusting that an incarnational theology can take seriously and not evade the core truths of our biological existence. ${ }^{25}$

\section{Eating and Being Eaten: A Eucharistic Vision}

In my "Rewilding Christian Spirituality" essay noted earlier, I described a piece of my own journey, as my long-standing experience of Jesus began to shift, culminating in an outdoor sabbatical during which "Jesus dissolved into the natural world," or, "the chancel walls gave way, and the whole world was now chancel." ${ }^{26}$ Only recently have I realized that, with this language, I was describing what I now consider a more satisfying view of Jesus' resurrection. If our theology is not to contradict

21 The severance of the practice of Eucharist from traditional practices of fasting in preparation for it (as well as diminished participation in Lenten fasting) means that the experience of real hunger in connection with Eucharist or in relation to one's daily food has also diminished in many places. On these connections, see Monika K. Hellwig, Eucharist and the Hunger of the World (Hellwig 1992), as well as Mary McGann, Meal that Reconnects (McGann 2020). Bill Plotkin explores the importance of fasting in relation not to religious practices like Eucharist but to the practice of extended wilderness immersion and spiritual deepening into a fully human maturity. See Soulcraft (Plotkin 2003, pp. 208-9, 213ff)

22 Lisa Sideris, Environmental Ethics, Ecological Theology, and Natural Selection (Sideris 2003), and Consecrating Science (Sideris 2017).

23 David B. Batchelder, "Baptismal Renunciations: Making Promises We Do Not Intend to Keep" (Batchelder 2007). Batchelder's essay is the springboard for my 2016 essay, "Life in All Its Fullness: Christian Worship and the Natural World" (Dahill 2016c), on bioregional adaptation of liturgical texts.

24 David Abram, Spell of the Sensuous (Abram 1997, p. 264)

25 This approach is Lutheran as well, in the sense noted above of Luther's insistence against Zwingli on the fundamental inherence of God in (sacramental) matter, as well as in Luther's hermeneutical privileging of the literal-rather than allegorical-meanings of scriptural texts. I here am similarly privileging the biologically literal truth of our lives, insisting that Christian theology must take it as seriously as biblical exegetes take the scriptural text. Dietrich Bonhoeffer embodies this Lutheran impulse in his unfinished Ethics, where he insists on the inseparability not merely of Jesus and the sacramental bread but of God and the world itself, joined fully and forever in the flesh of Jesus Christ. For Bonhoeffer, "reality" is visible only when this fundamental unity of God and the world in Jesus Christ is perceived, beheld. "There are not two realities, but only one reality, and that is God's reality revealed in Christ in the reality of the world" (Bonhoeffer 2005, p. 58). I explore these insights in "Addressing God with Names of Earth" (Dahill 2016a). In a paper delivered 22 November 2019, at the American Academy of Religion meeting in San Diego, I use them to propose a fundamental nondualism at the heart of Bonhoeffer's thinking. My use of the term "reality" in the present paper hews closer to Abram than to Bonhoeffer, in that I, too, sense the world itself and my sensory/animal engagement with it as the fundamental level of reality with which my theological thinking must reckon. I can use Bonhoeffer's language of Jesus Christ as that which (or the one who) so reconciles God and world that they are now inseparable - are in fact one reality — but I find Abram's biologically grounded thought, precisely as it opens to many forms of human symbolic meaning-making, to be even more compelling.

26 (Dahill 2016d, pp. 182, 181). 
biology, then Christians need to consider that we made a mistake (a category error, perhaps) in insisting that Jesus remain bound after death to the human shape of his life, ripping him out of his tomb in human form and refusing his body the much deeper primal grace of being allowed to decompose back into Earth, to rise again not as a mysterious human still able to eat and converse, but as a maggot Jesus, a trout Jesus eating the flies born from those maggots, a bear Jesus, a soil and grass and toad Jesus, juniper and cedar Jesus, and countless microbe and bacteria and fungi Jesuses as his molecules dispersed, as they surely longed to do, back into countless new forms of life: the resurrection! ${ }^{27}$

If we could grasp Jesus' own resurrection into the interspecies weirdness and glory and thrill of actual biological reality, might we be able to give Eucharistic thanks and celebrate our own hope of being resurrected into new forms and lives, our lives' bodily contribution toward real ongoing life, rather than the death our current human vision is creating on Earth? And if-by living closer to real hunger, perhaps, ramping way back our devouring of all that is-we were to grasp truly the intimacy and sweetness of being fed with the literal bodies and blood and flesh and life of actual living creatures, filled with that risen flesh of Jesus (or just miraculously themselves), and learn to give thanks not just for our food but to it in the most immediate and visceral I/Thou way, for that living creature's self-offering that will become remetabolized into my muscles and blood-if we could truly experience ritually and daily the gob-smacking miracle of all food as flesh of other creatures, our beloved real kin, more intimate to us than any lover as they literally come to comprise our own flesh, might we learn to give thanks also for that equal miracle of our own feeding of them, in our turn?

I want to live inside rites of baptism and Eucharist that take us so fully, completely, wildly inside our biological connection to other species and this whole beleaguered planet and the humans who urgently need our care along the way-so far inside all those relationships, physically and emotionally and intimately - that loving this life and these creatures, and humbly eating them and feeding them in turn, and listening to their needs, and acting to protect and cherish all this astonishing world is the Christian life itself: I want sacraments that enact this.

I'm haunted by a comment from a friend, also a scholar of Christian spirituality in heartfelt dialogue with contemporary eco-crises. Recounting a story of his preteen daughter and her recent existential encounter with the full implications of looming climate chaos and extinctions, my friend said, "nothing in [her] faith formation, or my faith formation, had prepared us to have this conversation, and to talk courageously and truthfully and faithfully about climate change." ${ }^{28} \mathrm{I}$ hear this story as an uncommonly honest articulation of the failure of the Christian tradition to take even its most faithful and thoughtful members deeply enough into reality: a profound indictment.

Rites that tell the truth about reality mean, among other things, Christian ritual language- - here, Eucharistic prayers- that break through our primal alienation as Plumwood's crocodile did, to help us experience our actual place in the actual biological world: a shock, to be sure, for those accustomed to be at the top of the food chain even unto eternal life-but a vision that is profoundly eucharistic, filled with gratitude and grace. A Christian vision doesn't have to contradict biology; it could invite us deeper into our own world, the miracle of being alive just as we are, here and now. My body really is meant to be eaten, and my great hope is to offer myself to become literal nourishment back to the suffering paradise that is Earth: I can do that by my body's excretion along the way-that's another chapter of this project-and I can give back in endless ways in my vocation and my citizenship and my

27 I am curious to explore a further aspect of Luther's Christological thinking, namely his insistence on the "ubiquity" of Jesus's risen body precisely in its flesh and physicality, after his ascension. That is, might this language of Luther's provide a more traditionally inflected (if, admittedly, also not universally accepted) way to speak of Jesus' resurrection into the physicality of all that is, the entire biosphere? On Luther and ubiquity, see Harold Ristau, "Ubiquity and Epiphany: Luther's Doctrine of the Lord's Presence in Space and Time" (Ristau 2013); Allen G. Jorgenson, "Luther, Ubiquity, and a Theology of the Public" (Jorgenson 2004).

28 Timothy Robinson, unscripted public comments (13 September 2019) following presentation of his paper, "Christian Hope (lessness) in the Anthropocene," at the BYU symposium, "On Being Vulnerable, Part II: Faith after the Anthropocene," at which the work gathered in this volume of Religions originated. 
love for the world and its creatures, including humans. And at the end, I can become the main course for nearby creatures, for a brief moment, in the huge glorious interspecies banquet that is life on Earth, to be fully remetabolized into countless other life forms, no personal me existing in some future realm. But I can't actually experience any of this explicitly, inter-species-ly, in any Christian Eucharist I know. This is my life's resurrection with Jesus, not some other heaven: my literal dissolving into Earth to feed its ongoing life. To know this reality in my bones-to receive precisely this ritually every week or every day in the practice of Eucharist-would be awesome grace. This is resurrection that does not undo kenosis but "deepens its mystery" further: new forms of life inseparable from the kenosis of one's human life. ${ }^{29}$

We who will dissolve with Jesus into Earth, our greatest joy, could then ritually ponder too what it might mean to die well, to give back as fully as possible to this divinely generous Earth, the source of our lives: this is my body ... this is my blood. And what would it mean to do so not only as individuals, as we must, but even to face our collective imperilment? What would it mean to die well as a nation, a society, a civilization, a species: to give back absolutely, as death requires and invites, to the present and future creatures who will receive our lives? These are our bodies, this is our blood ... This is the Eucharistic life.

So what kind of Eucharistic praying will open the crocodile shock-that jolt of knowing our radical vulnerability as meat to other creatures' jaws and mandibles and gullets, our resurrection with Jesus into their fur and feces, into blades of grass, snakes, and songbirds? I know many would not recognize my vision as Christian, stripped of the usual resurrection hope-which for many people is the entire point, the Gospel itself. But I offer it as the Eucharist we have needed all along, the Eucharist of reality, our re-entry to a world alive with gratitude and grace, wild energy and relationships, calling us to re-join it. Let's come home. With all who eat, as those who are eaten, let us learn to pray.

Funding: This research received no external funding.

Conflicts of Interest: The author declares no conflict of interest.

\section{References}

Abram, David. 1997. Spell of the Sensuous: Perception and Language in a More-than-Human World. New York: Vintage Books.

Augsburg Fortress. 2006. Evangelical Lutheran Worship. Minneapolis: Augsburg Fortress.

Batchelder, David B. 2007. Baptismal Renunciations: Making Promises We Do Not Intend to Keep. Worship 81: 409-25.

Bell, Catherine. 1997. Ritual: Perspectives and Dimensions. Oxford: Oxford University Press.

Bieler, Andrea, and Luise Schottroff. 2007. The Eucharist: Bodies, Bread, E Resurrection. Minneapolis: Fortress Press.

Bonhoeffer, Dietrich. 2005. Ethics. Edited by Clifford J. Green. Dietrich Bonhoeffer Works (DBWE). Minneapolis: Fortress Press, vol. 6.

Buell, Denise Kimber. 2014. The Microbes and Pneuma that Therefore I Am. In Divinanimality: Animal Theory, Creaturely Theology. Edited by Stephen D. Moore. New York: Fordham University Press, pp. 63-87.

Carnley, Peter. 2019. The Reconstruction of Resurrection Belief. Eugene: Cascade Books.

Carvalhaes, Cláudio. 2013. Eucharist and Globalization: Redrawing the Borders of Eucharistic Hospitality. Eugene: Pickwick Books.

29 I am grateful to an anonymous peer reviewer for the insight that my view of resurrection "substantially deepens how kenosis remains in effect even in a resurrected creation. Resurrection ... only deepens its mystery." Recent theological work on "deep incarnation" provides a foundation for my thinking, and I build on its insights as to the inseparability of the flesh of Jesus from the rest of the biosphere here and in other work. See the essays contained in Incarnation: On the Scope and Depth of Christology, ed. Niels Henrik Gregersen (Gregersen 2015), especially those by Gregersen, Elizabeth Johnson, Denis Edwards, and Holmes Rolston; and Denis Edwards, Deep Incarnation: God's Redemptive Suffering with Creatures (Edwards 2019). Johnson's essay in the Gregersen volume takes up questions of "deep resurrection," but her proposal does not grapple with questions of predation, asserting only "the salvation of everything, even of matter, even of bodily life, even of the whole cosmos, reconciled in the mystery of God" (Johnson 2015, p. 150). 
Conradie, Ernst. 2018. To Eat or Be Eaten? That's the Question. In The Bloomsbury Handbook of Religion and Nature: The Elements. Edited by Laura Hobgood and Whitney Bauman. London and New York: Bloomsbury Academic, pp. 63-78.

Dahill, Lisa E. 2016a. Addressing God with Names of Earth. Currents in Theology and Mission 43: 27-31.

Dahill, Lisa E. 2016b. Into Local Waters: Rewilding the Study of Christian Spirituality. Spiritus: A Journal of Christian Spirituality 16: 141-65. [CrossRef]

Dahill, Lisa E. 2016c. Life in All Its Fullness: Christian Worship and the Natural World. Liturgy 31: 43-50. [CrossRef]

Dahill, Lisa E. 2016d. Rewilding Christian Spirituality: Outdoor Sacraments and the Life of the World. In Eco-Reformation: Grace and Hope for a Planet in Peril. Edited by Lisa E. Dahill and James B. Martin-Schramm. Eugene: Cascade Books, pp. 177-96.

Douglas, Brian, and Terence Lovat. 2011. A Sacramental Universe: Some Anglican Thinking. Pacifica: Australasian Theological Studies 24: 190-209. [CrossRef]

Edwards, Denis. 2019. Deep Incarnation: God's Redemptive Suffering with Creatures. Maryknoll: Orbis Books.

Episcopal Church. 1979. The Book of Common Prayer. New York: Seabury Press.

Episcopal Church. 1998. Enriching Our Worship. New York: Church Publishing.

Falque, Emmanuel. 2016. The Wedding Feast of the Lamb: Eros, the Body, and the Eucharist. Translated by George Hughes. New York: Fordham University Press.

Gregersen, Niels Henrik, ed. 2015. Incarnation: On the Scope and Depth of Christology. Minneapolis: Augsburg Fortress.

Hart, John. 2006. Sacramental Commons: Christian Ecological Ethics. New York: Rowman \& Littlefield.

Hatley, James. 2004. The Uncanny Goodness of Being Edible to Bears. In Rethinking Nature: Essays in Environmental Philosophy. Edited by Bruce V. Foltz and Robert Frodeman. Bloomington: Indiana University Press, pp. $13-31$.

Hellwig, Monika K. 1992. Eucharist and the Hunger of the World. New York: Sheed and Ward.

Huck, Gabe. 1994. A Sourcebook about Liturgy. Chicago: Liturgy Training Publications.

Johnson, Elizabeth. 2015. Jesus and the Cosmos: Soundings in Deep Christology. In Incarnation: On the Scope and Depth of Christology. Edited by Niels Henrik Gregersen. Minneapolis: Augsburg Fortress, pp. 133-56.

Jorgenson, Allen G. 2004. Luther, Ubiquity, and a Theology of the Public. International Journal of Systematic Theology 6: 351-68. [CrossRef]

Kearney, Richard, and Brian Treanor, eds. 2015. Carnal Hermeneutics. New York: Fordham University Press.

Keller, Catherine, and Mary-Jane Rubenstein, eds. 2017. Entangled Worlds: Religion, Science, and the New Materialism. Transdisciplinary Theological Colloquia series; New York: Fordham University Press.

Lathrop, Gordon. 1998. Holy Things: A Liturgical Theology. Minneapolis: Fortress Press.

Luther, Martin. 1961. That These Words of Christ, 'This Is My Body', Still Stand Firm Against the Fanatics. In Luther's Works. Edited by Robert H. Fischer. Philadelphia: Fortress Press, vol.

McDougall, Dorothy C. 2003. The Cosmos as the Primary Sacrament: The Horizon for an Ecological Sacramental Theology. New York: Peter Lang.

McGann, Mary. 2020. Meal That Reconnects: Eucharistic Eating and the Global Food Crisis. Collegeville: Liturgical Press Academic.

Mendéz Montoya, Angel F. 2009. Theology of Food: Eating and the Eucharist. Malden: Wiley Blackwell.

Meyer, Eric Daryl. 2018. Inner Animalities: Theology and the End of the Human. New York: Fordham University Press.

Murphy, Erika. 2014. Devouring the Human: Digestion of a Corporeal Soteriology. In Divinanimality: Animal Theory, Creaturely Theology. Edited by Stephen D. Moore. New York: Fordham University Press, pp. 52-62.

O'Donnell, Hugh. 2012. Eucharist and the Living Earth, new and revised ed. Blackrock: The Columba Press.

Plotkin, Bill. 2003. Soulcraft: Crossing into the Mysteries of Nature and Psyche. Novato: New World Library.

Plumwood, Val. 1999. Being Prey. In The New Earth Reader: The Best of Terra Nova. Edited by David Rothenberg and Marta Ulvaeus. Cambridge: The MIT Press, pp. 76-91.

Plumwood, Val. 2012. Meeting the Predator. In The Eye of the Crocodile. Edited by Lorraine Shannon. Canberra: Australian National University Press.

Ramshaw, Gail. 2017. Pray, Praise, and Give Thanks: A Collection of Litanies, Laments, and Thanks at Font and Table. Minneapolis: Augsburg Fortress.

Ristau, Harold. 2013. Ubiquity and Epiphany: Luther's Doctrine of the Lord's Presence in Space and Time. Logia 22: 25-31. 
Sideris, Lisa. 2003. Environmental Ethics, Ecological Theology, and Natural Selection. New York: Columbia University Press.

Sideris, Lisa. 2017. Consecrating Science: Wonder, Knowledge, and the Natural World. Berkeley: University of California Press.

Stewart, Benjamin J. 2009. The Role of Baptismal Water at the Vigil of Easter in the Liturgical Generation of Eco-Theology. Ph.D. dissertation, Emory University, Atlanta, GA, USA.

United States Conference of Catholic Bishops. 2010. The Roman Missal. Washington, DC: United States Conference of Catholic Bishops.

Webb, Douglas. 1983. The Funeral Services of the Nestorian Church. In Temple of the Holy Spirit: Sickness and Death of the Christian in the Liturgy: The Twenty-First Liturgical Conference Saint-Serge. Edited by Matthew J. O'Connell. New York: Pueblo Publishing Company, pp. 288-301.

(C) 2020 by the author. Licensee MDPI, Basel, Switzerland. This article is an open access article distributed under the terms and conditions of the Creative Commons Attribution (CC BY) license (http://creativecommons.org/licenses/by/4.0/). 

Article

\title{
The Vulnerable (Post) Modern Self and the "Greening" of Spiritual Personhood through Life in the Spirit
}

\author{
Mary Frohlich \\ Catholic Theological Union, Chicago, IL 60615, USA; frohlich@ctu.edu \\ Received: 10 March 2020; Accepted: 14 April 2020; Published: 16 April 2020
}

\begin{abstract}
In the period now being called the Anthropocene, the fatal vulnerabilities of the modern way of constructing selfhood are becoming ever more evident. Joanna Macy, who writes from a Buddhist perspective, has argued for the need to "green" the self by rediscovering its participation in ecological and cosmic networks. From a Christian perspective, I would articulate this in terms of an imperative to rediscover our spiritual personhood as radical communion in both God and cosmos. In this paper, "self" refers to an ever-restless process of construction of identity based in self-awareness and aimed at maintaining one's integrity, coherence, and social esteem. I use the term "person," on the other hand, to refer to a relational center that exists to be in communion with other persons. How-within the conditions of the dawning Anthropocene-can the tension between these two essential aspects of human existence be opened up in a way that can more effectively protect human and other life on Earth? This would require, it seems, harnessing both the self-protective and the self-giving potentials of human beings. The proposed path is to give ourselves over into the rhythms of the Spirit, being breathed in to selfless personal communion and out to co-creation of our refreshed selfhood.
\end{abstract}

Keywords: Anthropocene; selfhood; personhood; Spirit; Christology; breathing; self-loss; transformed self

\section{Introduction}

In the period now being called the Anthropocene, the fatal vulnerabilities of the modern way of constructing selfhood are becoming ever more evident. Joanna Macy, who writes from a Buddhist perspective, has argued eloquently for the need to "green" the self by rediscovering its participation in ecological and cosmic networks. (Macy 2007, chp. 14) From a Christian perspective, this can be articulated in terms of an imperative to rediscover our spiritual personhood as radical communion in the God who creates and participates in the entire cosmos. The proposed path to this renewal is to give ourselves over into the rhythms of the Spirit, being breathed in to selfless communion in divine personhood and out to co-creation of our refreshed selfhood. (Frohlich 2019)

After this Introduction (Section 1), the three main parts of this essay will be: Section 2, an exploration of how the psychological process of "selfing" has changed in the postmodern era; Section 3 , an account of some ancient and contemporary developments in the Christian understanding of "personhood"; and Section 4, presentation of a perspective on the rhythms of the Spirit as offering hope for the greening of the self and the sustainability of the planet. 


\section{Basic Terminology}

"Self" and "person," as well as related words such as "soul" and "spirit," have different meanings in different systems of thought, so an initial clarification of usage is needed. In this essay, "self" refers to an ever-restless process of construction of identity based in self-awareness and aimed at maintaining one's integrity, coherence, and social esteem. Kenneth Schmitz wrote that the way of selfhood is that of "a resilient insistence upon an identity that preserves itself against others." (Schmitz 1991, p. 185) Thus, the "selfing" process is fundamentally self-centered (though not in a pejorative sense) and self-protective. It is as necessary to competent psychological function as having a skeleton is to walking. To fail to develop an adequately coherent and self-protective self is a severe pathology, and likely to result in behavior destructive to oneself and others.

I use the term "person," on the other hand, to refer to a relational center that exists to be in communion with other persons. This definition of personhood has arisen within the Christian tradition but has implications that are not limited to that milieu. The person loves, not for any extrinsic reason, but simply because being a person is to love. Personhood, then, is fundamentally relational and self-donative. Human infants are already persons. As parents attest, babies love, and call forth love, at the most profound level. It usually requires a lifetime of commitment to spiritual practice, however, to bring forth the full flowering of personhood in (relatively) selfless loving.

I say "relatively" because it is obvious that real human beings are always operating in both of these dimensions. Every human act deploys a complex dynamic of self-protection (selfhood) and self-giving (personhood). My purpose is by no means simply to denigrate the former and idealize the latter. It is, rather, to ask how - within the conditions of the dawning Anthropocene-this dynamic can be opened up in a way that can more effectively protect human and other life on Earth. This would require, it seems, harnessing both the self-protective and the self-giving potentials of human beings.

\section{Selfhood at the Dawn of the Anthropocene}

When exactly the tipping point into the Anthropocene era of decisive human influence upon all terrestrial cycles occurred is controversial, but I am looking upon it as the fruit of what we call "modernity." (Ruddiman et al. 2015; Ellis 2018) For our purposes here, the decisive shift in modernity was identified by René Descartes when he articulated the freedom of the human mind (the ego cogitans) in terms of disengagement from all material reality. One effect of this is to define the self as radically autonomous, rational, and world-dominating. This, in turn, justifies the unfettered technological manipulation of the natural world (including even our own bodies). It has been popular to say that we now live in a "postmodern" era, but it may be more accurate to say that we are in a transitional phase where the assumptions of modernity are in disarray while the struggle over what comes next is in full swing. Despite all the postmodern critique of both the style of selfhood and the often-destructive technological juggernaut that are characteristic of modernity, we are still fully immersed in living out their implications. (Giddens 1990; Harvey 1989)

\subsection{From the Autonomous Self to the Narrative Self}

A major component of what we call postmodernity has been a profound critique of the modern concept of selfhood. Today, at least in academia, the norm is to firmly reject the concept of the self as an autonomous interior entity that is transcendent to the body and the material world. Instead, the self is understood as an ongoing interpretive process conditioned by all aspects of the individual's embodied involvement in the world. In this postmodern view, the self is labile, dialogical, and (in a certain sense) "fictional," since it consists of an identity narrative that is selective and interpretive. (Eakin 2008; Teske 2017; McAdams 2006) Some go so far as to affirm a more radical "no self" perspective, somewhat along Buddhist lines—although even Buddhists are not fully in agreement with one another on the question of whether some kind of functional, though contingent, "self" exists on the psychological level. (Verhoeven 2010; Siderits et al. 2011) 
The consensus today, then, is to see the self as a story-telling process. The purpose of this "selfing" process is to interpret past, present, and imagined future in a way that maintains an inner sense of continuity, integrity, and meaningfulness while contributing to the fulfillment of one's social and material goals. Despite the aim of coherence and continuity, this story-telling process is actually highly responsive to changing relationships and circumstances. This means that there is likely to be more than one story line in process, and even within a given story line reinterpretation is constantly going on based on new circumstances or new goals.

In their book The Dialogical Self, Hubert and Agnieszka Hermans describe three types of "selfing": traditional, modern, and postmodern. Traditional selfing occurs in a social world perceived as unified, hierarchical, and authoritative. Insofar as the traditional self's storytelling mainly follows the cultural script, it is likely to maintain a deep sense of unity and "rightness." Modern selfing, shaped by an increasingly mechanized and anti-traditional world, tells its story in terms of the "sovereign self" whose inner core is separate from, and maintains power over, all that is other. The modern self emphasizes "personal goals, inner strength, overcoming resistance, personal achievement and heroism, masculinity, autonomy, future-orientation, progress, and control of the situation." (Hermans and Hermans-Konopka 2010, p. 89)

\section{2. "Selfing" in Late Modernity}

While both of these styles of selfing still exist, at the dawn of the Anthropocene it is what the Hermans call the "postmodern" style that is increasingly prevalent. In this style, centerless flux, fragmentation, and superficial play are the norm. A number of sociologists and psychologists have written about the extreme difficulty of constructing a viable form of selfhood under postmodern conditions. (Lifton 1993; Giddens 1997a; Gergen 2000) The most dominant challenge is that life in contemporary societies is characterized by a "swirling sea of relations" (Turner 2008, p. 44) that constantly change at a staggering rate. Daily life is saturated by media unceasingly spewing forth a cacophony of often-superficial stories that do not hang together or collectively point toward anything worthy of a life commitment. Meanwhile, everything-including the most intimate aspects of our identities, our relationships, and even our spirituality-has been commodified. Well-funded experts in "branding" work day and night to persuade us that if only we buy this particular clothing item, or this mood-enhancing dietary supplement, or this slick new spiritual practice, we will find happiness and success. Their goal, as sociologist Bernard McGrane puts it, is to convince us that "life becomes radiant through consumption." (Stein 1999)

In Kenneth Gergen's view, late modern culture has created homo optionis. To be human in this culture is defined by having at each moment a staggering array of identity options, among which we must constantly pick and choose. People can flit in and out of vast numbers of ever-shifting and often "virtual" relationships with people and groups around the world. Gergen terms this the "saturated self," whose efforts to maintain a coherent identity are overwhelmed by the number and incompatibility of invitations to self-investment that impinge upon it. He wrote: "As social saturation adds incrementally to the population of the self, each impulse toward well-formed identity is cast into increasing doubt; each is found absurd, shallow, limited, or flawed by the onlooking audience of the interior." (Gergen 2000, p. 73)

Some recent books give depressing portraits of how this postmodern culture shapes the self-making of young people in the US today. In Generation Me, Jean Twenge describes how child-raising styles since the 1990s have encouraged many young people to internalize a story in which being highly successful and wealthy is an option to which they are entitled. Any evidence to the contrary-e.g., the critical remarks of a teacher or work supervisor-is boomeranged back as a fault in the criticizer. (Twenge 2014) Meanwhile, seeking work, as well as searching for dating partners, requires day-and-night attention to building one's "brand" on social media. Twenge's research finds that as the anxiety to focus intensively on building one's personal brand grows, concern about politics, civic involvement, and environmental issues declines-and more so with each younger cohort. She also details how young people have 
completely tossed out the sexual mores of previous generations, in many cases preferring multiple "hookups" with no intention whatsoever of intimacy or ongoing relationship. This style of selfing seems to combine over-investment in receiving affirmation from large numbers of virtual relationships with a relative incapacity for the concrete give-and-take of committed face-to-face relationships.

In Kids These Days, Malcolm Harris describes how the system of capitalism has re-engineered all of life in view of increasing profits. He writes: "The growth of growth requires a different kind of person, one whose abilities, skills, emotions and even sleep schedule are in sync with their role in the economy." (Harris 2018, p. 5) If a young person internalizes these skills sufficiently to make it into college, they take on massive debt with the promise that the purchase of education is the guarantee of success. But once they graduate, they learn that the twenty-first century work world is brutal, often demanding a constant search for low-paying "gigs" without regular hours or health insurance. Anne Helen Petersen calls this "the burnout generation" because they are never offline-meaning by this not only the literally ever-present phone, but the never-ending internalized demand to be doing "something" to enhance one's brand and optimize one's possibilities. (Petersen 2019) A style of selfing maximized for capitalistic profit is neither satisfying nor, ultimately, sustainable for persons or communities.

\subsection{Ultimate Vulnerability: The Failure of the Self-Protective Function of Selfing}

Much more could be said, but the question these studies raise is whether the type of selfhood emerging within this late modern world has any possibility of sustaining a future for humanity. Self-making is meant to be self-protective, but in its current form it is failing to fulfill the function of protecting human life and legacy beyond the present generation. The fatal vulnerability remains that of modernity: the separation of the self from its integral connection with the natural world. What seems to be happening at the dawn of the Anthropocene is that both separated partners-Earth, and human selves-are spiraling in tandem towards destructive, out-of-control "overheating." For the Earth, the spiral of overheating is intensifying pollution and climate change. For humans, the spiral of overheating is a style of selfhood that has lost touch with both inner and outer sources of meaning, stability, and resilience. These two spirals are feeding each other, with increasingly deadly consequences.

The question at hand is whether there remains any possibility that this dawning Anthropocene era of deep human intertwinement with Earth processes could still give birth to another possibility—one in which we humans reclaim the self-protective value of recalibrating our self-making in responsiveness to the Earth processes with which we are, in fact, completely interdependent. This is what Macy called "the greening of the self," and it appears to be the only scenario in which our Earth can be sustained as a habitat for humans (and vast numbers of other species) for more than a few more decades.

\section{Perspectives on Personhood}

A positive answer to the above question, I believe, will require attention to a dimension even more profound than selfhood, namely "personhood." As will be evident from what follows, I write about personhood from the perspective of a Christian theologian. I want to emphasize, however, that my intent is not to restrict the value of the insights only to those who are of the Christian faith. The approach to personhood that has developed within Christian theology may have something important to offer when placed in dialogue with the quite different approach that predominates in many current philosophical discussions.

\subsection{Early Christian Understanding of Personhood}

In Greek, "person" is prosopon, which seems to derive from terms meaning "face to face" or "facing toward." It came to be associated with the masks worn in Greek theatre, in which humans wrestled tragically to enflesh freedom and identity in the face of the unity and necessity of the cosmos. (Papantoniou 2004, pp. 61-62) The early connotations of personhood, then, include face-to-face relations in which individual agency is exercised. From the time of Tertullian (3rd c. CE), persona (the 
Latin translation of prosopon) was used in Western Christianity to characterize God in the doctrine of the Trinity. Eastern thinkers, however, preferred the term hypostasis or "concrete individual reality" since they saw prosopon/persona as lacking ontological content. Eventually, the two terms came to be identified with each other and to condition one another. The theological definition of "person" as a concrete, individual reality known only within a "face to face" relationship of love was coming to be born.

It was within the fifth and sixth century debates over how to understand who Jesus was in relation to both humanity and divinity, however, that the most significant theological developments of the concept of personhood emerged. Many Christological theories were being presented, some stressing the dynamic unity of Christ's consciousness and agency while others fiercely argued that it is essential to affirm the "twoness" of both human and divine elements. In 451, the First Council of Constantinople famously attempted to resolve these debates by declaring that Jesus had two natures (human and divine), which came together in one prosopon ("persona" or self-presentation), and one hypostasis (concrete individual). Another Council in 527 would make explicit the affirmation that the one "person" of Christ is the divine Word of God.

As Brian E. Daley has detailed, at its inception the Chalcedonian formula was a rather hastily composed compromise which was, no doubt, only superficially understood by many of the Council Fathers who approved it. Daley argues that the formula's composers did not intend it as a sweeping speculative theology of the relation between God and the world (as it has subsequently been interpreted to be), but rather as a set of loose boundaries for orthodoxy. (Daley 2016) Indeed, in the immediate aftermath, this formula actually aroused more controversy rather than resolving the issues as the Council's organizers had hoped. Despite this rather shaky start, the formula of "two natures, one person" became more and more embedded in orthodox Christian tradition as a foundation stone of Christology. Over the subsequent 1600 years of theological thought, its interpretation has been repeatedly developed and deepened in dialogue with the prevailing insights of each era.

\subsection{Zizioulas and the Ontology of Personhood}

Most recently, the Orthodox prelate Jean Zizioulas has argued in favor of what he calls an "ontology of personhood." He does not define personhood primarily in terms of consciousness or communion, but rather in terms of free self-donation. Zizioulas builds his argument on the assertion that the Cappadocians (4th c. CE), whose thought lies behind the Chalcedonian formula, had an insight that radically redirected the Greek philosophy of the time. For the Greeks, only two ontologies were possible: monism, in which "the being of the world and the being of God formed ... an unbreakable unity"; or gnostic dualism, in which there was a radical gulf between God and the world. (Zizioulas 1985, pp. 17-18) Early Christians clearly rejected dualism as incompatible with scriptural revelation, but monism was problematic as well because of the way it eliminates the freedom of God in relation to the created world-and of the created world in relation to God.

The new insight of the Cappadocians, according to Zizioulas, was that God is not "substance" but "person." The most central characteristic of personhood is that persons exist only in a free and mutual relationship of love with other persons. (LaCugna 1991, pp. 289-92) As divine person, God freely creates the world and freely enters into personal relationships with creatures. On this basis the Cappadocians also developed the doctrine of the Holy Trinity as one divine nature in three persons-that is, one God differentiated by nothing except relations of complete mutual self-giving. This notion of subsisting relations was further clarified in the thirteenth century by Thomas Aquinas. The Trinity, then, is characterized by "total and undiminished self-donation; absolute orientation to the other." Personal giving and receiving "is the very being of Begetter and Begotten." (Schmitz 1991, p. 200)

The challenge of articulating this view of personhood is that, since divine relationality is not reducible to any created manifestation, any discussion of it ultimately has to point to an essentially apophatic dimension. This challenge becomes acute in attempting to explain the core Christological distinction of "two natures" and "one person." If both "nature" and "person" were identified as 
involving contingent aspects of the human individual, an implication would be that central aspects of human nature (e.g., natural capacities for freedom, knowledge, love) would have to be removed from Jesus, so as to be substituted by divine personhood. Theologians insist, however, that divine personhood does not substitute for any aspect of human nature, which remains complete and fully functioning. Since divine personhood is not an aspect of created reality, but rather can only be indicated in apophatic terms, it is able to operate in and through every aspect of Jesus's humanity without in any way disrupting the ongoing natural operation of human functioning. In the context of this essay, an implication of this is that personhood does not eliminate or replace the natural and contingent process of "selfing."

\subsection{The Personhood of Human Beings—and Others}

Based in the definition of personhood as capacity for free relations of mutual self-giving, early Christian thought went on to affirm human beings as also having our most fundamental reality and dignity as "persons." The intrinsic relationality that characterizes the divine persons in the Trinity is also central for human persons insofar as human fulfillment is destined to be found in the freely-entered communion of human beings with each other and with God. Human persons, then, are free, capable of loving, and fundamentally designed for mutual intimacy. Persons are never static or reified beings who can be known objectively, but rather are intrinsically relational creatures who can only truly be known relationally. The Christian view is that this is true from our beginning in receiving life as a gift from a personal God to our end in fulfilled communion with divine and human persons.

In the context of the Anthropocene and the acute ecological crisis that accompanies it, the attribution of personhood exclusively to human beings is being challenged. If personhood is the most central reality of the Creator-God, why presume that it is shared only with human creatures and not with others? Many indigenous cultures have presumed the opposite, affirming that personhood can be exhibited by animals, plants, geographic features, and even stones. In a much-discussed essay, anthropologist Irving Hallowell recounts asking an Anishinaabe elder about whether all the stones around them are alive. The elder answered "No, but some of them are." (Hallowell 1960, p. 24) Exploring this in depth, Graham Harvey finds that in this indigenous perspective, to be a person is to be in relationship in a respectful and reciprocal way. The most basic quality of personhood is to know when and how to participate in gift-giving. Thus, some stones, animals, plants, etc. are persons-but some may not be. In fact, in this perspective, the same is true of human beings: we have to become persons though concrete and appropriate participation in relationships. Thus, Harvey observes that when Europeans first met Native Americans the Europeans asked, "Are they human?" But the Native Americans' implicit question was, "Are they persons?" (Harvey 2017)

In her book Spirit Unleashed: Reimagining Human-Animal Relations, Anne Benvenuti draws on both her own experience and a wide array of contemporary scientific and philosophical literature to argue that the assertion of a radical distinction between human and animal "souls" is not only false, but deadly for both humans and animals. (Benvenuti 2014) Over twenty years ago, Langdon Gilkey argued that all creatures should be seen as sharing in some vestigial way in the "image of God"-a phrase from Genesis 1:27 that has traditionally been assumed to apply only to humans. (Gilkey 1993, pp. 175-92) In a recent book, Franciscan theologian Daniel P. Horan reviews a variety of approaches to the question of human exclusivism (e.g., that only humans are made in the image of God) and concludes by proposing a Scotist approach that prioritizes the unique, unrepeatable, and particular character of each and every created entity. In his view, this relaxes the problem of defining "natures" and placing them in hierarchical order, with human nature nearest to God; instead, every creature has its own unique and individual relationship with God. (Horan 2019, chp. 3)

Building on all these ideas, my proposal is to explore the possibility that if "personhood" is defined not in terms of a nature or substance, but as relationality itself, it can be seen as the image of God that forms each creature in its own unique way. It is evident that every creature is utterly dependent on its relations, even though the specific structure of how this plays out is unique. The indigenous insight 
described by Harvey is that many types of creatures (not only humans) may participate in relations in ways that affirm universal kinship and build communities of love and respect. This is evidence of some level of participation in personhood.

This raises the question of whether, if some humans do not behave in an appropriate personal manner by building relationships of kinship and communion, they may not qualify as "persons." Christian tradition has strongly resisted such a conclusion, affirming that all human beings, regardless of their virtue or sinfulness, are persons and so are intrinsically worthy of being related to with love and respect. In the context of modern philosophical thought, however, when the predominant definition of personhood typically is something along the lines of Locke's "a thinking intelligent being, that has reason and reflection, and can consider itself the same thinking thing, in different times and places," (Quoted in Rowlands 2016; from Locke 1961, p. 280) it has been difficult to see how infants or those with severe intellectual disabilities could qualify. Defining personhood in terms of relationality relieves this impasse, since affective and embodied relationship does not require advanced cognitive abilities. (See Brown 1998. Brown applies a similar argument to the question of "soul.") At the same time, this approach necessarily opens the door to considering at least some non-human beings as participating in personhood.

\subsection{Personhood as Participation in Divine Personhood}

It is important to recall that personhood is not to be understood as a "deeper level" of selfhood, nor is it a distinct identifiable "place" or "function" within natural entities. Rather, it is an apophatic participation that potentially can operate in and through natural created life. In my view it is, in fact, the participation of creatures in the personal reality of God. The personal God freely embraces all of creation in loving relationship, and each creature is formed into some degree of capacity to mediate that personhood. If all creatures share in some way in divine personhood, can we still say that humans are so constructed as to be capable of enfleshing the divine character of personhood more completely or more perfectly than other kinds of creatures? This is a point to be debated, but what matters far more-especially at this crisis point in the history of life on Earth—is that we humans actually find a way to maximize our enfleshment of personhood, to whatever degree we are capable.

In my view, the potential to be a mediator of divine loving personhood is not contingent upon having faith in God or belief in specific doctrines; it is simply how we have been created. Every human being is born to give and receive personal love, to weave bonds of community, and ultimately to be welcomed into union with God. It is evident, however, that this capacity to love is concretely manifested to greater and lesser degrees in different individuals. I would propose that the difference may be located in each one's individual history of the development of selfhood. There are some people in whom trauma or other pathologies has led to a distorted self-protectiveness that seems to so profoundly obscure any capacity to give or receive love that it may require great conviction even to believe that they have potential to manifest relational personhood. And there are others in whom the story of the self is permeated with such generosity, kindness, and radiance that one barely notices any self-protective tendencies, as one is so quickly drawn into a sense of loving relationship with the person. Most of us, of course, fall somewhere in between these two more extreme possibilities.

The challenge at the dawn of the Anthropocene is that our very survival as a species is calling for a vastly broadened and deepened level of relationality-one which reaches out to interact respectfully and appropriately with all other species, geological processes, and the Earth itself by including them as our "kin." The survival of our species, and of the Earth as a richly biodiverse ecosystem, needs us to be persons - that is, creatures defined by, and living to the full, our capacity for self-giving love-in a fresh and profound manner. Yet, in this moment of Earth crisis, the predominant style of human self-making instead seems to be tending toward superficiality, fragmentation, and-frankly-narcissism. Is it possible for such weak and broken selves to rediscover and develop the relational potential of their personhood? 


\section{The Revitalizing Rhythms of the Spirit}

Obviously, the answer to the above question is complex. Sometimes weakness and vulnerability can create openings for a positive breakthrough to renewed and deepened strength, while in other cases they only lead to descent into increased chaos and devastation. My goal in this section is to describe how the relational personhood of God, in the person of the Holy Spirit, strives always and everywhere to enhance the possibility of the former.

\subsection{The Rhythm of "Lost" and Renewed Selfhood}

A good place to begin is with the gospel report that Jesus said, "The one who saves their life will lose it, and the one who loses their life for my sake shall save it." (Matthew 16:25; Luke 9:24.) The word here translated as "life" is actually psyche, which could equally be translated as "self." But this saying is hard to interpret. Is Jesus saying that one should actually eliminate, or radically minimize, all manifestations of our self-protective selfhood? Those who try this usually end up bringing worse evils not only upon themselves, but upon others as well. Selfhood can no more be eliminated from our psychological life than the skeleton can be cut out of the body. A better interpretation, in my view, is that "losing" the self means being open-we could even say, vulnerable-to significant change in the embedded story of the self. The question is, how does truly positive change in the story of the self happen - that is, change toward a style of selfhood that allows the radiance of personhood to operate more freely?

My proposal is that it happens through the rhythms of the divine Spirit who breathes in all of creation. (These ideas are developed more fully in Frohlich 2019) "Breathing" is, of course, a metaphor, since divine Spirit is not operating in the same dimension as any form of created movement. Divine Spirit is better compared to a non-material field (something like gravity or magnetism) that moves objects without itself having material presence. The in and out breathing of the Spirit manifests the ever-present divine invitation both to abandon oneself completely in radical communion with God, and to emerge with a renewed self that is more fit for collaboration with God in mission. Just as breathing in and breathing out require one another, and neither can occur unless a rhythm is established between them, so the Spirit works in human life through the necessary and repeated rhythm of "losing" and renewing the self.

The first movement of the rhythm occurs as the Spirit breathes us in to an ecstatic communion of love with God in which our relational personhood blossoms in joy. While sometimes such an experience can be intense and prolonged, more often it is like a glimpse or a hint that is gone before one even begins to grasp what has occurred. When I have asked people to write about a "spiritual experience" that they have had, it is this sort of moment that most recount. It may occur in the context of prayer or religious ritual, of course, but it is just as likely to come out of nowhere in the midst of ordinary life. No one can program such a moment, although many kinds of spiritual practice are designed to awaken our desire for such communion and to shift our attention toward its possibility. I call this the "way of emptiness," because the communion that we glimpse is fundamentally apophatic; that is, it is beyond capturing in any words, images, practices, or feelings. It is an event in which our communion in personhood shines forth in its fullness-even if only for the briefest of moments.

I call the second movement of the rhythm of the Spirit, in which the self is reconstructed afresh, "the way of remembering." This plays on both the role of memory, and the alternate meaning of "re-membering" or making a new whole. Since the story of the self is founded in an interpretation of memories, a renewed story requires a revised interpretation of what has happened in one's life, as well as of the potential this creates for a desired future. Even a moment of glimpsing the infinite, overflowing love that constitutes one's personhood-whether experienced as joy, wholeness, cosmic oneness, or radical love-can change the story of one's life. When someone is asked to recount the story of their most significant choices and conversions, such events will typically be found in or near the nodes of change. 
Unfortunately, change in the deeply embedded patterns of our selfhood is never easy, and many forms of resistance waylay our ability both to abandon ourselves and to allow ourselves to be re-membered afresh. For the traditional style of self, resistance perhaps most often takes the form of a kind of rigidity based in a narrow set of cultural expectations for how one ought to live a meaningful life. For the modern style of self, resistance may be withdrawal into the fortress of one's presumed autonomy and domination. In the postmodern self-style, resistance may be the unwillingness to take anything seriously—even the looming devastation of the planet and the potential demise of our own species.

\subsection{Hope for the Greened Self}

The Spirit has its ways, however. My conviction is that the Spirit is always and everywhere breathing in and around us. We have been created by and for this rhythm of both self-giving personhood and self-protecting selfhood. Those who write about how to get people to vote or act for ecological causes have pointed out that it is usually more effective to focus first on how the proposals will benefit them and their children and grandchildren-in other words, to appeal first to the self-protective self. The much deeper change that the dawn of the Anthropocene urgently demands, however, will require also awakening the self-giving personhood that is our most profound human heritage. In this emerging Anthropocene era, it is more imperative than ever that human beings find the path to living as responsive and responsible kin within a sustainable Earth community.

How can this come to be? Here we must return again to consider the "vulnerability" that is identified in the title of this essay, as well as others in this symposium. The self is instinctively self-protective because, like every created thing, it is intrinsically vulnerable: that is, it is constantly subject to wounding, disintegration, and death. But this vulnerability can have two potential outcomes. One potential of vulnerability is that instability may catastrophically compound into spiraling levels of chaos, violence, and fragmentation. The paradox of the instinct of self-protection is that if it is left on its own without the complementary movement of self-giving, the ultimate result is self-destruction. This is what we fear when we speak of the negative vulnerability of the postmodern style of selfing, with its tendencies to narcissism and other pathologies.

The alternative potential of vulnerability, however, is what psychiatrist Kazimierz Dabrowski calls "positive disintegration": the fragmentation that necessarily precedes the emergence of integration at a higher level. (Dabrowski 2016) The positive vulnerability of the postmodern style of selfing could be that it is far more open to change than were previous styles. Still, this change will only be truly "positive" when the rhythm of the Spirit is fully engaged. I am convinced that the Spirit offers every human being, regardless of their beliefs and circumstances, invitations to participate in the radical communion of love that has borne us into being. In those often-brief glimpses, one realizes, if only for a moment, what it means to be released beyond self into joyfully self-giving personhood. The self is "greened" when we open ourselves to such moments and take on the challenge of breathing with the Spirit, who will not neglect to protect our truest self while drawing us ever-deeper into the even more profound truth of our personhood.

Funding: This research received no external funding.

Conflicts of Interest: The author declare no conflict of interest.

\section{References}

Benvenuti, Anne. 2014. Spirit Unleashed: Reimagining Human-Animal Relations. Eugene: Cascade Books.

Brown, Warren S. 1998. Cognitive Contributions to Soul. In Whatever Happened to the Soul?: Scientific and Theological Portraits of Human Nature. Edited by Warren S. Brown, Nancey C. Murphy and H. Newton Malony. Theology and the Sciences. Minneapolis: Fortress Press, pp. 99-125. 
Dabrowski, Kazimierz. 2016. Positive Disintegration. Anna Maria: Maurice Bassett.

Daley, Brian E. 2016. Unpacking the Chalcedonian Formula: From Studied Ambiguity to Saving Mystery. The Thomist 80: 165-89. [CrossRef]

Eakin, Paul John. 2008. Living Autobiographically: How We Create Identity in Narrative. Ithaca: Cornell University Press.

Ellis, Erle C. 2018. Anthropocene: A Very Short Introduction. New York: Oxford University Press.

Frohlich, Mary. 2019. Breathed into Wholeness: Catholicity and Life in the Spirit. Catholicity in an Evolving Universe. New York: Orbis Books.

Gergen, Kenneth J. 2000. The Saturated Self: Dilemmas of Identity in Contemporary Life. New York: Basic Books.

Giddens, Anthony. 1997a. Modernity and Self-Identity: Self and Society in the Late Modern Age. Stanford: Stanford University Press.

Giddens, Anthony. 1990. The Consequences of Modernity. Stanford: Stanford University Press.

Gilkey, Langdon. 1993. Nature, Reality, and the Sacred: The Nexus of Science and Religion. Theology and the Sciences. Minneapolis: Fortress Press.

Hallowell, A. Irving. 1960. Ojibwa Ontology, Behavior, and World View. In Culture in History: Essays in Honor of Paul Radin. Edited by Stanley Diamond. New York: Columbia University Press, pp. 19-52.

Harris, Malcolm. 2018. Kids These Days: Human Capital and the Making of Millennials. New York: Back Bay Books/Little Brown and Company.

Harvey, David. 1989. The Condition of Postmodernity: An Enquiry into the Origins of Cultural Change. Cambridge: Blackwell.

Harvey, Graham. 2017. If Not All Stones Are Alive ... : Radical Relationality in Animism Studies. Journal for the Study of Religion, Nature \& Culture 11: 481-97.

Hermans, Hubert J. M., and Agnieszka Hermans-Konopka. 2010. Dialogical Self Theory: Positioning and Counter-Positioning in a Globalizing Society. Cambridge: Cambridge University Press.

Horan, Daniel P. 2019. Catholicity and Emerging Personhood: A Contemporary Theological Anthropology. Catholicity in an Evolving Universe. Maryknoll and New York: Orbis Books.

LaCugna, Catherine Mowry. 1991. God For Us: The Trinity and Christian Life. San Francisco: HarperSanFrancisco.

Lifton, Robert Jay. 1993. The Protean Self: Human Resilience in an Age of Fragmentation. New York: BasicBooks.

Locke, John. 1961. An Essay Concerning Human Understanding. London: J.M. Dent and Sons.

Macy, Joanna. 2007. World as Lover, World as Self: Courage for Global Justice and Ecological Renewal. Berkeley: Parallax Press.

McAdams, Dan P. 2006. The Problem of Narrative Coherence. Journal of Constructivist Psychology 19: 109-25. [CrossRef]

Papantoniou, Anthony. 2004. The Mystery of the Human Person in Orthodox Theology: Some Reflections. Phronema 19: 59-77.

Petersen, Anne Helen. 2019. How Millennials Became the Burnout Generation. BuzzFeed News. January. Available online: https://www.buzzfeednews.com/article/annehelenpetersen/millennials-burnout-generation-debtwork (accessed on 15 April 2020).

Rowlands, Mark. 2016. Are Animals Persons? Animal Sentience. 10. Available online: https: //animalstudiesrepository.org/animsent/vol1/iss10/1/ (accessed on 15 April 2020).

Ruddiman, William F., Erle C. Ellis, Jed O. Kaplan, and Dorian Q. Fuller. 2015. Defining the Epoch We Live in. Science 348: 38-39. [CrossRef]

Schmitz, Kenneth L. 1991. Selves and Persons: A Difference in Loves? Communio 18: 183-206.

Siderits, Mark, Evan Thompson, and Dan Zahavi, eds. 2011. Self, No Self? Perspectives from Analytical, Phenomenological, and Indian Traditions. New York: Oxford University Press.

Stein, Todd. 1999. Zen Sells: How Advertising Has Co-Opted Spirituality. Lion's Roar: Buddhist Wisdom for Our Time. November. Available online: https://www.lionsroar.com/zen-sells-how-advertising-has-co-optedspirituality/ (accessed on 15 April 2020).

Teske, John A. 2017. Knowing Ourselves by Telling Stories to Ourselves. Zygon: Journal of Religion E Science 52: 880-902.

Turner, Léon. 2008. Theology, Psychology and the Plural Self. Burlington: Ashgate. 
Twenge, Jean M. 2014. Generation Me: Why Today's Young Americans Are More Confident, Assertive, Entitled-and More Miserable than Ever Before, rev. and updated ed. New York: Atria Paperback.

Verhoeven, Martin J. 2010. Buddhist Ideas about No-Self and the Person. Religion East E West 10: 93-112.

Zizioulas, John D. 1985. Being as Communion: Studies in Personhood and the Church. Crestwood: St. Vladimir's Seminary Press.

(c) (1) BY

(C) 2020 by the author. Licensee MDPI, Basel, Switzerland. This article is an open access article distributed under the terms and conditions of the Creative Commons Attribution (CC BY) license (http://creativecommons.org/licenses/by/4.0/). 

Article

\title{
The Saving Grace of America's Green Jeremiad
}

\author{
John Gatta \\ Department of English, University of the South, Sewanee, TN 37375, USA; jogatta@sewanee.edu
}

Received: 10 March 2020; Accepted: 2 April 2020; Published: 6 April 2020

\begin{abstract}
By the late seventeenth century, Puritan leaders in colonial America were bemoaning what they perceived to be the betrayal of New England's godly "errand into the wilderness." In election sermons they mourned the community's backsliding from its global mission as a "city upon a hill." Such doomsday rhetoric echoed the lamentations of decline intoned by ancient Hebrew prophets such as Jeremiah. Yet this "Jeremiad" discourse characteristically reached beyond effusions of doom and gloom toward prospects of renewal through a conversion of heart. It blended warnings of impending catastrophe with hope for recovery if the erring souls it addressed chose to repent. This twofold identity of the Puritan Jeremiad, gradually refashioned into the American Jeremiad, has long resonated within and beyond this nation's literary culture. Featured in creative nonfiction, jeremiad expression surfaces in various forms. And with rise of the modern environmental movement, a prophetic subspecies identifiable as "Green Jeremiad" has lately emerged. The essay reflects on how, especially in an Anthropocene era, Green Jeremiads dramatize the crisis of spirit and faith that undergird challenges to earth's geophysical health and survival. What saving graces might temper the chilling reminders of imminent peril composed by authors such as Rachel Carson, Bill McKibben, Barbara Kingsolver, and Elizabeth Kolbert?
\end{abstract}

Keywords: jeremiad; anthropocene; saving grace; rhetoric; doomsday; spiritual crisis; climate change

At the moment, it's fair to say, we find ourselves painfully aware of our vulnerability in the face of multiple perils-threats not only to the geophysical environment we inhabit but also, on the national scene, to our trust in democratic processes and the rule of law. Yet ours is scarcely the only such crisis juncture in American history. From the nineteenth century, for example, we recall the nearly catastrophic fracturing this nation endured amid the horrors of civil conflict. And earlier still in our history, beyond the sturdy resolve projected by first waves of Anglo-European settlers, New England's second- and third-generation Puritan leaders bemoaned the way their land of divine promise had already by 1650 begun to fall sinfully, disastrously short of fulfilling what minister John Danforth described in 1670 as its singular "errand into the wilderness." 1

Moreover, in election sermons and diverse polemical writings reflecting a literary subgenre known today as the "jeremiad," New England's would-be prophets felt bound to pour out their dismay at the land's declension toward apostasy and to warn her citizens, in lurid terms, of the supreme woes toward which they were now headed in defiance of God's wrath. Here was vulnerability with a vengeance - even, so it seemed to them, divine vengeance. For America's new city of the saints, once set upon a hill, had lapsed now into a faithless abyss unworthy of its biblical promise. All sorts of worldly woes—disease, drought, warfare, communal dissension and dissolution—had followed from

1 Leading scholars of the Puritan Jeremiad commonly invoke Danforth's election sermon, preached in 1670, as a landmark illustration of the genre. Such commentators have included Perry Miller, Sacvan Bercovitch, Emory Elliott (Elliott 1994), and David Mintner (Mintner 1974). Study of colonial New England's version of this genre therefore rests on a firm foundation and has also, in the case of Bercovitch's book, addressed subsequent adaptations and modifications of the Jeremiad tradition in America-aside from relevant, latter-day environmental writings, which have yet to be seriously evaluated in the light of that tradition. 
her apostasy. Yet the essence of this crisis, as her leaders perceived it, was neither physical, nor social or political, but spiritual.

Expanding on the earlier work of some eminent twentieth-century scholars such as Perry Miller (Miller 1953) and Sacvan Bercovitch (Bercovitch 1978), I argue here that the Puritan jeremiad, as circumstances refashioned it over time into a form definable in broader terms as the American jeremiad, has had an enduring and decisive influence on our culture to the present day. I would claim, in fact, that a latter-day subset of the American Jeremiad that I'll call in oxymoronic zeal "the Green Jeremiad" has been flourishing in our own age of environmental peril and carries timely significance for the planet at large. Permutations of the Green Jeremiad have appeared thus far in multiple literary genres, in works by American authors as varied as Rachel Carson, Jonathan Schell, Ed Abbey, Gary Snyder, Bill McKibben, Barbara Kingsolver, Elizabeth Kolbert, and David Wallace-Wells. Artistry of the Green Jeremiad is likewise evident in a number of contemporary film documentaries associated with figures such as Al Gore (An Inconvenient Truth, 2006) and Leonardo di Caprio (Before the Flood, 2016). But I first want to consider how the strategic logic of all these works follows at least consistently-if not always causally or self-consciously-from the precedent set by New England's Puritan rhetoricians.

To be sure, the Puritan jeremiad conveyed God's own plenty of doom and gloom. A note of alarm, of terror and disillusionment, suffuses even the titles attached to many New England compositions from this era, an age of anxiety leading toward the infamous Salem Witchcraft trials of 1692 . I have in mind titles like the one that accompanied the Reverend Michael Wigglesworth's versified account of "God's Controversy with New-England, written in the time of the Great Drought, 1662," or his widely read poem dramatizing "The Day of Doom." The tenor of such writing sounds fairly chilling, even today; and as someone whose scholarly investigation once focused on the religious culture of colonial New England, I ended up reading more Puritan sermons, histories, and poetic lamentations than most persons would ever volunteer to absorb.

Striving to interpret the adversities New England faced during a period of severe drought and waning piety, Michael Wigglesworth, in one of his verse expositions struggled to understand, for example,

How is it, that Security, and Sloth,

Amongst the best are Common to be found?

That grosser sinns, in stead of Graces growth,

Amongst the many more and more abound.

This O New-England hast thou got

By riot, \& excess:

Beware, O Sinful Land, beware;

And do not think it strange

That sorer judgments are at hand,

Unless thou quickly change. (Wigglesworth 1968, pp. 48-49, 53)

Yet as some scholars pointed out decades ago, the essence of the Puritan "jeremiad"—and, by extension, the American jeremiad-was not purely denunciatory. The form should not, in other words, be seen as simply an ireful tirade, an outpouring of near-despair over the state of society and the world. For true Jeremiads looked to do more than expound their authors' litany of woes because they reached beyond effusions of doom and gloom toward a prospect of renewal. Above all, they blended warnings of impending catastrophe with a faith-grounded hope for recovery if the erring souls they addressed chose to repent. If, that is, they accepted the imperative set before them to alter their current course. As 
Wigglesworth declared, "sorer judgments are at hand/Unless thou quickly change." Thus the aspect of choice is crucial. In this regard the Jeremiad differs markedly from another literary subgenre-likewise drawn from Old and New Testament sources-we have come to know as apocalyptic. Apocalyptic, which prefigures an ultimate disclosure expected to be inevitable, rarely highlights the decisive, still-latent potential of human choice. Neither does the visionary future envisioned in most religious forms of apocalyptic resemble the earthy immediacy of the jeremiad, which situates its moral critique of some particular place and time within a discrete setting of sociopolitical conditions.

It is worth recalling that even an ancient Hebrew prophet so forbidding as the original Jeremiah, back in the seventh century before Christ, seems to have understood his vocation of oracular speech as inspiring visions not only of divine destruction but also of potential restoration and redemption. For "if you turn back" from your evil ways, insists the prophet on behalf of his Lord, "I will take you back," Oh Israel, and "you shall stand before me" (Jeremiah 15:19, NRSV version).

In fact some of New England's jeremiad prophets, including the Reverend Samuel Willard in his 1682 election sermon on "The Only Sure Way to Prevent Threatened Calamity," took their homiletic text directly from Jeremiah. But what virtually all these jeremiads shared rhetorically was a ritual invocation of three elements: a Recollection of better times, a Recognition of the current state of declension, and an exhortation to Return to better faith and conduct.

The first element called for a Recollection and affirmation of how promising things had once seemed for the Puritans' original community of faith in the New World. "What affectionate care was there one of another," recalled Samuel Danforth, during that idealized era of "our first and best times" which preceded "the loss of our first love." Why, after all, had the fathers of New England pursued their holy "errand" overseas in the first place, daring to pass "over the vast ocean into this waste and howling wilderness?" (Danforth, in Plumstead 1968, pp. 65, 73). Then, in sounding the second theme, the jeremiad prophet typically pressed his hearers to acknowledge their apostasy with "full and free consent," recognizing "that the hand of God is out against this people awful in tokens of wrath" (Willard, in Plumstead 1968, p. 97). Yet in the sermon's final, or "Uses" phase, the preacher moved toward assuring "this people" of God's willingness to save them from future calamities if they swiftly repented to seek an amendment of life, a reformation of their faith and practices. Preachers like Samuel Willard painted a threatening picture of woes looming ahead but offered as well "a way to escape" (Willard, in Plumstead 1968, p. 98)—albeit a narrow way, requiring collective resolve.

Thus the future in jeremiad perspective-though doubtful, frightening, mostly grim-remains open rather than predetermined. This hortatory, marginally hopeful characteristic of the American jeremiad may owe something to this nation's original faith-a faith grounded not only in divine providence, but also-through the early federal-Jeffersonian period-in the resilience and creative resolve of its own citizenry. The saving grace of the jeremiad lies especially in its residue of hope, its insistence that with enough common resolve we may yet avoid perdition because it is now almost but not quite too late to change course.

The blended warning of a peril to come with a call for immediate reformation, as reflected in the Puritan Jeremiad, has long continued to resonate through the course of American literary culture-as reflected, for example, in Harriet Beecher Stowe's masterwork, Uncle Tom's Cabin. And despite Stowe's agonistic relation to her own Puritan-Calvinist heritage, she animated her narrative in that novel with evangelical passion so as to inspire in her readers a zeal for conversion. For Stowe, this call to conversion of heart resounded in two dimensions at once-spiritually and inwardly, toward a new birth of Christian faith and repentance, as well as morally and socio-politically, toward solidarity with the abolitionist cause of immediate emancipation. The Jeremiad subtext of this imperative was unmistakable. For by 1852, when the novel first appeared, Stowe deemed the nation headed swiftly toward cataclysm, a horrific consequence of the original sin of slaveholding that rendered America vulnerable to divine judgment. A destructive upheaval lay ahead-unless the citizenry Stowe addressed moved with alacrity to welcome God's new birth. So in her concluding, overtly homiletic chapter Stowe voiced a hope that such turn and rescue might still take place. Ever the evangelist, 
Stowe ends up intoning, before her congregation of all America, God's promise of salvation if those she addresses awaken to their peril and respond now in faith:

A day of grace is yet held out to us. Both North and South have been guilty before God; and the Christian church has a heavy account to answer. Not by combining together, to protect injustice and cruelty, and making a common capital of sin, is this Union to be saved-but by repentance, justice and mercy; for, not surer is the eternal law by which the millstone sinks in the ocean, than that stronger law, by which injustice and cruelty shall bring on nations the wrath of Almighty God! (Stowe 2018, p. 418)

What circumstances, then, gave rise eventually to the green jeremiad? What purpose and special character did this subspecies come to assume?

Celebrated writerly naturalists such as Henry Thoreau, John Muir, and Aldo Leopold all played a role in that story. But for the purpose at hand I propose leaping ahead now to 1962, recalling the seminal text of latter-day environmentalism that Rachel Carson published in that year: Silent Spring.

The bad news Carson feels charged to convey in this prophetic work is signaled from the first, in its ominous yet provocative title. "Silent Spring" becomes an all-encompassing augury-at first tied to a single chapter-that the author's agent, Marie Rodell, helped her settle on. And just past the title page, on the dedication page where Carson honors Alsatian polymath Albert Schweitzer, known among other things for championing the principle of "reverence for life," readers presently encounter this withering prediction: "To Albert Schweitzer who said 'Man has lost the capacity to foresee and to forestall. He will end by destroying the earth.'" Destroying the earth—scarcely by this time, a fancifully remote prospect, seventeen years after first use of thermonuclear weapons at Hiroshima and Nagasaki, and a decade after first detonation of the hydrogen bomb. Neither would readers scanning the Contents page find much encouragement there. Among its headings are these foreboding tags: "Elixirs of Death," "Needless Havoc," and "The Rumblings of an Avalanche."

The book's subsequent elaboration of these themes is replete with technical explanations, documentation, and manifold examples of the havoc wrought by the massive, indiscriminate application of chemical pesticides such as DDT. Left unchecked, such practices meant to target insect pests threatened not only to silence songbirds, but also to pollute plants, fish, domestic animals, soil, and water. So as commentator Lisa H. Sideris has observed, they threatened, in effect, to silence the "nonhuman world" itself (Sideris 2008, p. 137). Moreover, as these toxic insecticides are carried up the food chain, poisoning human diets and bodies, they also become toxic to human life and health. Chapter 12, "The Human Price" enlarges upon the unpredictable yet frightful "effects of lifetime exposure to chemical and physical agents that are not part of the biological experience of man" (Carson 1962, p. 188). And in two subsequent chapters, Carson describes the terrifying danger that toxic pesticides pose, by way of genetic influence on future generations - to say nothing of their potential, still undetermined today, as carcinogens. This last reminder carries a poignant irony, too, insofar as the author was struggling at the time to finish writing her book while herself battling breast cancer.

A more encompassing cultural indictment emerges from the densely expository middle chapters of Silent Spring. Carson certainly acknowledged that humans had just cause, with the benefit of science, to intervene selectively in natural processes-especially, where feasible, through biological rather than chemical means. But for her the supposition that humans can and should fully control nature was another matter-an arrogant, self-destructive fantasy. It led ultimately, she claimed, to the folly of waging war against the very natural order-with its "fabric of life" — that sustains us. A misguided conception of science, having "armed itself with the most modern and terrible weapons," has thus ended up turning them, unwittingly, not only toward the annihilation of insects but "against the earth" (Carson 1962, p. 297).

None of this, needless to say, comes as welcome news. So why read such a book? What saving grace, amid the dire warnings, could possibly render this volume not only palatable to Carson's readers but a best-seller in its day? 
Part of the answer, I'd suggest, lies in the grace of Carson's rhetorical artistry and logic. Consider, for example, that celebrated opening chapter, "A Fable for Tomorrow." From the outset, it invites readers to contemplate the pastoral loveliness of a fictive town in America's heartland where "all life seemed to live in harmony with its surroundings." Such an all-American settlement with its "prosperous farms," “countless birds" (Carson 1962, pp. 1-2), and colorful botanical life would strike readers as altogether familiar. Undoubtedly, too, it presents an appealing image, one that lingers in imagination throughout the book as an ideal against which to measure the immense loss facing us were that town's mysterious blight to engulf the whole of actual America.

An even clearer opening toward grace then confronts us from the start of the final chapter, titled "The Other Road." Here Carson as jeremiad prophet calls for a collective conversion of heart that's still possible but requires a decisive shift in attitude, practice, and public policy:

We stand now where two roads diverge. But unlike the roads in Robert Frost's familiar poem, they are not equally fair. The road we have long been traveling is deceptively easy, a smooth superhighway on which we progress with great speed, but at its end lies disaster. The other fork of the road-the one "less traveled by" — offers our last, our only chance to reach a destination that assures the preservation of our earth.

The choice, after all, is ours to make. (Carson 1962, p. 277)

That Carson here images the nation's current path toward perdition as a superhighway strikes me as oddly, provocatively apt for its time. For in the early 1960s, America's interstate highway system of limited-access roadways was still fairly new. Superhighways, which swiftly changed the character of communities they encompassed or bifurcated, including those near Carson's home in Silver Spring, Maryland, seemed to be sprouting up everywhere. Promising unsurpassed speed, efficiency, and convenience of motorized transport, they represented for many a visible fulfillment of America's postwar ambition to lead the world into a new golden era of industrial-technological progress. Few then considered what might be lost along the way-with respect to the fracturing of settled communities that superhighways often brought about, or the diminishment of felt connection with the land that motorists would henceforth be experiencing en route to their destination.

But Carson wanted readers to recognize that the easier path of a quick-fix to pest control through saturation with pesticides posed more than a physical threat to the health of America's citizenry. If no birds sang, that would likewise set at risk everyone's spiritual welfare and aesthetic satisfaction with the world they inhabit. ${ }^{2}$ Preserving these trans-material values, and the earth's larger integrity, would require a novel, thoughtfully variable approach. Hence Carson's concedes, amid the prevailing gloom of her final chapter, that change is still possible but insists that a humbler, less direct way toward future development than technocracy's superhighway represents our "last, our only chance to reach a destination that assures the preservation of our earth."

The publication of Silent Spring in 1962 was arguably a crucial event in the flourishing of what I have been calling the American green jeremiad. From that time to the present moment, a multitude of other writings have appeared to address grave environmental perils of one sort or another. Several of these works, particularly those expressed in essayistic form, consciously reflect and absorb the example set by Rachel Carson. Several, too, reach beyond warnings of our bodily peril to underscore the spiritual, psychological liabilities of environmental degradation. All of them, though, participate in the precedent set by Silent Spring and, more distantly, by those colonial-era New Englanders.

2 Despite the significant progress made since 1962 in limiting the destructive use of pesticides, Carson's specter of muted birdsong has proved to be prophetic. In addition to the mass extinction of species, a major, ominous decline in the overall population of North American birds has also taken place over the last forty years-leading to quieter if not silent springtime music in our own day. (Zimmer 2019) Carl Zimmer's recent New York Times article, drawing on scientific reports published elsewhere, on how "Birds are Vanishing from North America," discloses that some three billion fewer North American birds—a 29\% decline-remain alive in 2019 as compared with 1970. 
What array of authorial personalities, literary genres, and subject choices might come to light, then, in an overview of green jeremiads that postdate Silent Spring? A few subspecies of that genre deserve mention before I attend more expansively to the recent emergence of climate change literature.

One inescapable topic of jeremiad treatment was — and, I hasten to add, plainly still is — the threat of nuclear war. Although this shadow has darkened prospects for sustenance of all earthly life since 1945, particularly during the Cold War era, Jonathan Schell's book The Fate of the Earth, which appeared in 1982, attempted to dramatize in memorable, grisly detail the likely consequences of an all-out nuclear holocaust. For Schell, unfolding that horrid scenario at the outset represents a first step toward enabling readers to apprehend, fully and emotionally, the threat's imminent actuality, since "it may be only by descending into this hell in imagination now that we can hope to escape descending into it in reality at some later time" (Schell 1982, p. 5).

For decades now, too, Wendell Berry, has inveighed against the unsustainable character of America's mainstream farming practices, with their reliance on chemical modes of soil support and pest control. Berry's agrarian critique of the so-called Green Revolution, of the decline of family farming along with the close-knit ethos of rural communities, of the depersonalizing effects of over-industrialized food production and the growth of agribusiness-all of these themes have long figured across multiple genres of Berry's writing. One can sense the jeremiad force of this testimony from early on in Berry's vocation, as in the title of his 1977 volume on The Unsettling of America. (Berry 1977)

The anthropogenic extinction of certain favored animal species has presented another cause for alarm in latter-day green jeremiads. Thus the threatened demise of large crustaceans, especially sperm whales, became a prominent issue by the 1970s. A poetic amalgam of the jeremiad complaint with psalm-like praise of this signature animal gained prominence, for example, with the publication of Gary Snyder's verse oration, "Mother Earth, Her Whales," included in his Pulitzer-prize winning volume of 1974, which bore the eco-implicated title of Turtle Island (Snyder 1974). Peter Matthiessen enlarged upon the theme of diminished biodiversity in the second version (1987) of his Wildlife in America. "No one can doubt," he concluded there, "that the world confronts an unprecedented impoverishment of the diversity of life," a crisis in the making that "will be the exclusive work of man." Indifference to the loss of species is effectually, he claimed, an "indifference to the future" that threatens to leave us "fatally diminished as a species" (Matthiessen 1987, pp. 279-80).

By 2014, Elizabeth Kolbert in her volume titled The Sixth Extinction: An Unnnatural History, was calling attention to the unprecedented scale and acceleration of humanity's latter-day erasure of species. Although for Kolbert this mass extinction of manifold plant and animal species bears some resemblance to catastrophic upheavals from earth's geophysical past, its anthropogenic agency marks something new under the sun. And with coral reefs, the integrity of earth's oceans, and the survival of many amphibian and other species all thrown into peril, it contributes toward a fundamental and degrading alteration of earth's environment, dubbed now the era of the anthropocene. "No creature has ever altered life on this planet in this way before," Kolbert writes (Kolbert 2014, pp. 2-3). Thus enmeshed in what she calls a pivotal "extinction event of our own making," we can scarcely refrain from wondering "what happens to us?" One ironic possibility, as Kolbert observes in her concluding chapter, is that "we, too, will eventually be undone" (p. 267), rendered extinct as a species by the very transformations we have brought about. Homo sapiens could thus end up as both agent and victim of the anthropocene. That prospect, wherein "everything people have written and painted and built" will have "been ground into dust" (p. 269), leads us to contemplate an abyss of existential vulnerability even more unsettling than that borne by cognizance of our personal mortality.

Some of these latter-day writings blend the fearful, admonishing tone of the jeremiad with other modes of expression. In that light we should at least note in passing Ed Abbey's prophetic discourse in his Desert Solitaire: A Season in the Wilderness (Abbey 1968). Cactus Ed held strong views, after all, about the welfare of wildlands-above all, desert spaces surrounding Arches National Park near Moab, Utah-that he regarded as vulnerable to desecration despite, or perhaps because of, their federally designated status. Thus assuming the voice of a brashly oracular Jeremiah, he labels a key chapter of 
his book "Polemic" —followed in subtitle by "Industrial Tourism and the National Parks." And in the book's "Down the River" chapter, set nearby in Arizona, Abbey blends his primary mode of personal narrative with social satire, an adventure tale, and a kind of jeremiad-elegy over the flooding of idyllic Glen Canyon. Here Abbey excoriates what he takes to be the profanation of nature's sacred sanctuary and waterway, the ruin of an irreplaceable beauty, through this imposition of a damned dam onto the Colorado River.

What choice or saving grace could Abbey possibly offer, though, in recounting such a never-to-be repeated journey through canyonlands whose fate had already sealed by the time the book appeared? True, Glen Canyon was gone for good. Too late for hope of conversion there. Yet Abbey's testimony, like John Muir's failed campaign to save Hetch Hetchy Valley, effectively galvanized public support for future preservationist bids at other sites in the region near Grand Canyon, including dam projects that had been proposed at Marble Canyon and Bridge Canyon. To that extent Abbey's writing helped to transform the demise of Glen Canyon, beautifully elegized as well by photographer Eliot Porter, into something of a generative calamity.

Of course no perilous circumstance of the anthropocene era now draws more attention than our environment's momentous, accelerated alteration in the face of climate change. Much attention has even been directed lately toward a new literary subgenre called "climate fiction" or ClifI. It is represented, at its best, by a work such as Barbara Kingsolver's novel Flight Behavior (Kingsolver 2012), which finds an objective correlative for the disruptions effected by climate change in the anomalous patterns of monarch butterfly migration as witnessed by characters residing in my own region of rural Tennessee.

Yet nonfictional prose represents the largest share of what qualifies as classic American environmental literature, including those latter-day versions of the green jeremiad meant to dramatize the imminent, all-encompassing danger posed by climate change. Anxiety over the progress and consequences of climate change doubtless figures now as the chief environmental issue of our time.

Accordingly, the last green jeremiad I want to consider here is Bill McKibben's landmark exercise of environmental journalism, titled The End of Nature, published back in 1989. Since 1989 McKibben has gone on to publish many other writings. He has also served in any number of public roles as social critic, prophetic voice, and environmental activist in leading movements such as 350.org. Since 1989, to be sure, much of the statistical and other data presented in The End of Nature needs revision, given all we have learned about the relevant earth science and measurable changes over the last thirty years. Relevant writings, whatever their literary standing, by commentators such as Elizabeth Kolbert and David Wallace-Wells (The Uninhabitable Earth: Life After Warming, Wallace-Wells 2019) do incorporate such updated findings. Why, then, might The End of Nature still be regarded as a seminal and indispensable work, even arguably as the essential green jeremiad of our time?

For one thing, this book played a pioneering role in drawing climate change-otherwise known then as global warming - to the serious attention of America's public at large at a time when the issue had as yet received little recognition beyond the small circle of scientific specialists. In this volume McKibben, much as Carson had done, takes pains along the way to explain for nonspecialist readers the science behind the peril he perceives, to offer plentiful evidence of global warming's reality and major impact on our world. While questions remain about the particular, long-term consequences of climate change, and while much of the quantitative data McKibben supplied in 1989 needs updating, one should also note that the book's dire predictions sound, if anything, understated in light of the ever-accelerating climactic changes we have been witnessing lately. Or as David Wallace-Wells declares, in the opening salvo of his recent, withering assessment, "It is worse, much worse, than you think" (Wallace-Wells 2019, p. 3).

The End of Nature still deserves to be read for other reasons, too. To begin with, it reflects a grace and force in its mode of presentation that qualifies as authentically literary. And like other enduring specimens of American environmental literature, its larger argument is enlivened and humanized by personal testimony. The book's voice and storytelling interludes-from the opening chapter all 
the way to final paragraphs-help to situate us sympathetically on this author's home ground, amid the forested lake country of New York State's Adirondack Mountains. And the ecology of literary fellowship that McKibben invokes within the larger course of his presentation amounts to a who's who of American nature writers across time: from the eighteenth-century botanist-explorer William Bartram to landmark authors such as Henry Thoreau, George Perkins Marsh, John Muir, John Burroughs, Rachel Carson, Ed Abbey, Loren Eiseley, Barry Lopez, and Wendell Berry. They all participate in the choir of witnesses that McKibben orchestrates.

The work's figurative and rhetorical artistry likewise contributes to its impact. Part of McKibben's rhetorical strategy here is to foreground his description of climate change-an almost unimaginably invisible and unlocalized form of environmental deformation-by challenging readers to reconceive the way they apprehend space and time. He points out how the headlong pace of present-day climate shifts challenges their most fundamental expectations about earth-space and geological earth-time. So just as we are inclined to "think of time as imponderably long, we consider the earth to be inconceivably large" (McKibben 1999, pp. 5-6). But the earth we now inhabit conforms to neither of these expectations.

Consider, too, some of the figurative re-visioning developed in this book. McKibben notes, for example, how the greenhouse effect might aptly describe not only the way trapped atmospheric gasses have elevated temperature levels, but also the many ways in which we human beings have unwittingly, across the entire earth, "built a greenhouse-a human creation-where once there bloomed a sweet and wild garden" (p. 91). This greenhouse earth comes to resemble yet another human artifice writ large. What then might it mean, we're pressed to wonder, to find now that "we are at the end of nature"? Surely, too, McKibben intends that telling phrase, "the end of nature" to have a broadly figurative rather than literal import. By the "end of nature," he writes,

I do not mean the end of the world. The rain will still fall, and the sun will still shine. When I say "nature," I mean a certain set of human ideas about the world and our place in it. But the death of these ideas begins with concrete changes in the reality around us, changes that scientists can measure and enumerate. More and more frequently, these changes will clash with our perceptions, until our sense of nature as eternal and separate is finally washed away and we see all too clearly what we have done. (McKibben 1999, p. 8).

Philosophically, another connotation of the "End" of nature leads us to muse upon its telos-that is, its putative meaning, purpose, and essential character. In such a light Ralph Waldo Emerson, in his landmark 1836 volume entitled Nature poses this question from the outset: "Let us inquire, to what end is nature?" (Emerson 1983, p. 7)

Above all, McKibben's book dramatizes the point that the vulnerability we're forced to confront with the anthropogenic end of nature involves still more than a momentous threat to our physical health and survival as a species. More even, than a threat to the health and survival of manifold species and ecosystems. For the end of nature, McKibben argues, also occasions for our species a profound crisis of spirit. It poses an existential challenge to our personal and collective identity, our capacity for faith even in the possibility of godliness - that is, of any form of self-transcendence, our capacity henceforth to apprehend any essential reality beyond ourselves. Humanity's pride in its seemingly supreme power to create a kind of shopping mall earth issues in deep sorrow and loneliness, McKibben writes, because in the final analysis "there's nothing there except us" (p. 89). So we are henceforth left to answer to no one but ourselves - both individually and collectively-for whatever we do. And in place of God, we suppose ourselves to be the only deities over earth worthy of our knowledge and belief. This new idolatry leaves us unable to reverence anything or anyone outside ourselves, ${ }^{3}$ to apprehend our contingent yet potentially satisfying place within the larger, wondrous expanse of Creation. In sum, the end of nature carries a "faith-shattering" potential (McKibben 1999, p. 79).

3 (Woodruff 2001) Philosopher Paul Woodruff, in his discourse on Reverence: Renewing a Forgotten Virtue, offers a revealing perspective on the legacy and broadly non-parochial, trans-cultural implications of "reverence." 
But this crushing jeremiad does hold out to readers, at least as of 1989, some prospect of saving grace. Recalling Rachel Carson's exhortation from 1962 to choose the road "less traveled," McKibben (whose writing, like Carson's and Kolbert's, had appeared first in pages of The New Yorker magazine) observes that we "could exercise our reason to do what no other animal can do: we could limit ourselves voluntarily, choose to remain God's creatures instead of making ourselves gods" (McKibben 1999, p. 214). For remarkably enough, he points out, state political leaders had once chosen, for example, to adopt policies that reversed the previous course of deforestation in the Adirondack woodlands surrounding his home in New York State, thus enabling a "second-chance wilderness" to emerge there. Fortunately, too, the world had "shifted course" in other ways following Carson's jeremiad warning about the deleterious effects of DDT.

Yet McKibben was in 1989-and certainly still is-far from underestimating the obstacles to our civilization's changing its response to climate change. To advance that case with as much force and urgency as possible, he relied not only on an array of scientific evidence and explanations, but also on personal narrative and anecdote, on an array of literary invocations from American naturalist writers and from Milton's Paradise Lost - even, from the faith perspective of his own Methodist Christianity, on an appeal to biblical texts. Perhaps surprisingly, the chief biblical text that informs his essay is the Hebrew Book of Job, about which he ended up writing another full though brief volume of commentary (The Comforting Whirlwind: God, Job, and the Scale of Creation) (McKibben 1994). In the Job-author's dramatization of earth's blessedly wild creatures-mighty Behemoth, Leviathan, and the rest-McKibben locates the expansive, enspirited vision of a Creation vastly larger than ourselves. So he finds the testimony of God's voice from the whirlwind, though chastening indeed, to be revelatory. Here is how, within The End of Nature, he sums up the earthy force of that revelation:

The Old Testament contains in many places, but especially in the book of Job, one of the most far-reaching defenses ever written of wilderness, of nature free from the hand of man. The argument gets at the heart of what the loss of nature will mean to us.... Finally, God arrives, a voice from the whirlwind. But instead of engaging in deep metaphysical discussion, he talks at some length about nature, about concrete creation... "Behold now Behemoth," booms God. "He eateth grass as an ox, his strength is in his loins... Shall any take him when he is on watch, or pierce through his nose with a snare?" The answer, clearly, is no; the message, though not precisely an answer to Job's plaint, is that we may not judge everything from our point of view - that all nature is not ours to subdue. (McKibben 1999, pp. 75-76)

In this cultural moment, when we face a more accelerated threat to climate stability and environmental sustainability across the globe than formerly suspected, sustaining the jeremiad's traditional reserve of hopeful exhortation has itself become problematic. Hopelessness, in fact, seems more than slightly warranted. Scientists confirm that even if international initiatives to reduce carbon dioxide and methane emissions were shifted promptly into high gear-as now seems unlikely-it would already be too late to reverse or even to halt the overall slide toward atmospheric degradation, too late to restore the wondrous old earth of preindustrial memory. Evidently, too, the least privileged members of the human family must continue to bear the worst consequences of humanity's dereliction in this regard. As activist Peterson Toscano points out, the ecojustice consequences of climate disruption are such that "we may all be in the same boat, but we are not all on the same deck" (Toscano 85, in Schade and Bullitt-Jonas 2019). And without some currently unimaginable breakthrough in technology, apparently the best outcome we might expect now-if we even dare to call such a desideratum "hope" - is some mitigation of those otherwise grave debasements of planetary life and health that now seem inevitable.

In the face of all this, the green jeremiad's traditional appeal to hoped-for change becomes indeed problematic, ambiguous if not downright futile. Yet ambiguity and paradox are of course the lifeblood of literary expression, arguably the stuff of life itself. What Mary Evelyn Tucker has termed a "tsunami of sadness" (Tucker xiii, in Schade and Bullitt-Jonas 2019) that engulfs all who care deeply about the climate crisis might thus serve at least to remind us that the virtue of Christian hope cannot 
be simplistically equated with temperamental optimism or wishful thinking. Best understood as a cultivated outgrowth of faith and love, it arises instead from a radical trust in, and abandonment to, a divine presence beyond ourselves, trust in the eschatological mystery of redemption. So within this mortal life it remains, like that which it aspires to achieve, a work-in-progress rather than a stable presumption.

From the standpoint of this elusive, self-contradictory version of gospel "hope," all human initiatives to combat and overcome the climate crisis must be regarded as impossible indeed-and yet, paradoxically, an imperative. As the arresting headline of one op-ed contribution to the New York Times puts it, "Stopping Climate Change is Hopeless: Let's Do it."4 Hope of this sort looks to live fully within, rather than in denial of, the encircling bounds of grief, discouragement, disillusionment, and near-despair. Thus critic Roger Gottlieb, in a discerning recent essay titled "Living with Environmental Despair," concludes that "what is called for" at this juncture "is perhaps neither hope nor hopelessness-but courage to live with the fear," given that "despair, I suspect, will for the indefinite future be a permanent part of an awakened consciousness" (Gottlieb 168, 167, in Schade and Bullitt-Jonas 2019).

In the final analysis, then, what might we name as chief saving graces of America's Green Jeremiad tradition, as we look beyond its graphic depiction of some ruinous future lying ahead of us? For one thing, green jeremiads confront us with a bracing declaration of the truth of things. They press us to see where we really are, where we and our fellow creatures must now be headed as a consequence of what we have done with and to the earth we have inherited, especially within the last thirty years. There is arguably a grace latent in just that much clear factual honesty, particularly in this post-truth era of public discourse, even when the truth in question happens to be inconvenient, unwelcome, or something we already know as abstract fact but have yet to absorb existentially. Or as Jonathan Schell prophesied, back in 1982 concerning the world's nuclear sword of Damocles, "At present, most of us do nothing. We look away ... We deny the truth that is all around us" (p. 230).

"We deny the truth that is all around us" —still largely true, it seems, of this nation's practical response to climate change. But green jeremiad authors insist upon holding open for the moment some prospect for seeing or doing otherwise, despite their hopeless prognosis for recovering an earth of fond remembrance. A distant echo thus remains audible from those decades ago when Rachel Carson ended her best-known book with a chapter titled "The Other Road," or Jonathan Schell with a chapter titled "The Choice." And though Bill McKibben in 1989 saw through Nature's End with such penetration that he could only "hope against hope" to see anything else, he, too, grants that we're still invited to choose between "humble" and more dismissively "defiant" approaches to the specter of climate change (McKibben 1999, p. 193). And choosing the humbler path of relative austerity, whatever its practical result, helps at least to shatter the illusion of our radical self-sufficiency as masters of the world we inhabit, both as individuals and collectively.

I would sound one last note about the green jeremiad's potential for transformative grace. For the chastening, hortatory passion of the Jeremiad author likewise conveys its own testimony of faith-faith, at least, in the readership's resilience, moral seriousness, and capacity for change, if not in a divine wellspring of transformation. It is, after all, by virtue of such faith, that the better angels of our nature might be awakened by argument, that prophetic writers find cause to launch their jeremiads in the first place. To alter if not reverse earth's current course of anthropogenic degradation doubtless requires a godly abundance of faith, imagination, and resolve. Conversely, though, the green jeremiad might also contribute toward our recalling, and summoning up, the requisite faith.

Perhaps it is no wonder, then, Bill McKibben concludes his classic jeremiad of 1989 by directing our gaze not down to all the environmental degradations, present and future, from which we shrink

4 From an op-ed piece by Auden Schendler and Andrew P. Jones published on 6 October 2018, cited by Jim Antal, at the start of his essay on "Fighting Climate Change: Our Responsibility, Our Vocation, Our Salvation," 123 in Schade and Bullis-Jonas. 
but upward, toward the starlit heavens. In such a light, he writes of the deep satisfaction he and his wife once felt, late at night atop a rocky northern summit, under a clear August sky, as they beheld with fresh confidence how "This vast nature above our atmosphere still holds mystery and wonder" (McKibben 1999, p. 217).

Funding: This research received no external funding.

Conflicts of Interest: The author declares no conflict of interest.

\section{References}

Abbey, Edward. 1968. Desert Solitaire: A Season in the Wilderness. New York: Ballantine Books.

Bercovitch, Sacvan. 1978. The American Jeremiad. Madison: University of Wisconsin Press.

Berry, Wendell. 1977. The Unsettling of America: Culture and Agriculture. San Francisco: Sierra Club Books.

Carson, Rachel. 1962. Silent Spring. New York: Houghton Mifflin.

Elliott, Emory. 1994. The Jeremiad. In The Cambridge History of American Literature. Edited by Sacvan Bercovitch and Cyrus Patell. New York: Cambridge University Press, vol. 1, pp. 255-78.

Emerson, Ralph Waldo. 1983. Emerson: Essays and Lectures. Edited by Joel Porte. New York: Library of America. Kingsolver, Barbara. 2012. Flight Behavior. New York: Harper Perennial.

Kolbert, Elizabeth. 2014. The Sixth Extinction: An Unnatural History. New York: Henry Holt and Company.

Matthiessen, Peter. 1987. Wildlife in America. New York: Viking Penguin.

McKibben, Bill. 1994. The Comforting Whirlwind: God Job, and the Scale of Creation. Grand Rapids: Wm. B. Eerdmans. McKibben, Bill. 1999. The End of Nature. New York: Anchor-Doubleday.

Miller, Perry. 1953. The New England Mind: From Colony to Province. Cambridge: Harvard University Press.

Mintner, David. 1974. The Puritan Jeremiad as a Literary Form. In The American Puritan Imagination: Essays in Revaluation. Edited by Sacvan Bercovitch. New York: Cambridge University Press, pp. 45-55.

Plumstead, A. William, ed. 1968. The Wall and the Garden: Selected Massachusetts Election Sermons, 1670-1775. Minneapolis: University of Minnesota Press.

Schade, Leah D., and Margaret Bullitt-Jonas, eds. 2019. Rooted and Rising: Voices of Courage in a Time of Climate Crisis. Lanham: Rowman \& Littlefield.

Schell, Jonathan. 1982. The Fate of the Earth. New York: Alfred A. Knopf.

Sideris, Lisa. 2008. The Ecological Rachel Carson, Silent Spring, and Breast Cancer. In Rachel Carson: Legacy and Challenge. Edited by Lisa H. Sideris and Kathleen Dean Moore. Albany: SUNY Press.

Snyder, Gary. 1974. Turtle Island. New York: New Directions.

Stowe, Harriet Beecher. 2018. Uncle Tom's Cabin, 3rd ed. Edited by Elizabeth Ammons. New York: W.W. Norton. Wallace-Wells, David. 2019. The Uninhabitable Earth: Life after Warming. New York: Crown-Random House.

Wigglesworth, Michael. 1968. God's Controversy with New-England. In Seventeenth-Century American Poetry. Edited by Harrison T. Meserole. New York: W.W. Norton.

Woodruff, Paul. 2001. Reverence: Renewing a Forgotten Virtue. New York: Oxford University Press.

Zimmer, Carl. 2019. Birds are Vanishing from North America. New York Times. September 19. Updated September 22. Available online: https://www.nytimes.com/2019/09/19/science/bird-populations-america-canada.html (accessed on 1 January 2020).

(C) 2020 by the author. Licensee MDPI, Basel, Switzerland. This article is an open access article distributed under the terms and conditions of the Creative Commons Attribution (CC BY) license (http://creativecommons.org/licenses/by/4.0/). 

Article

\title{
Returning Faith to Knowledge: Earthlings after the Anthropocene
}

\author{
Whitney A. Bauman \\ Department of Religious Studies, Florida International University, 11200 SW 8th St, Miami, FL 33199, USA; \\ wbauman@fiu.edu
}

Received: 10 March 2020; Accepted: 1 April 2020; Published: 4 April 2020

\begin{abstract}
The technologies of the Anthropocene are based upon Modern certainties. These technologies of a reductive and productive model of science create the worlds in which we live, in the image of a particular human being: the modern, western anthropos (with its raced, sexed, and gendered body). This article explores some of the technologies of the Anthropocene, and the environmental and social problems they give rise to. Finally, this article argues for the development of multiple planetary technologies based in uncertainty about the planetary future, that open humans onto more just and ecologically sound possibilities for planetary becoming.
\end{abstract}

Keywords: globalization; climate change; Anthropocene; planetarity

\section{Introduction}

The fact that the universe apparently generates the conditions for the emergence of ... civilizations (we are, in fact, here) tells us that, to the best of our guesses, we are part of a game of chance and of skill, a kind of cosmic evolutionary process, which in turn gives us a realistic hope that we might make it through. (Or not.) Realistically speaking, our chances are somewhere between abysmal and possible. So it makes sense to try. (Ivakhiv 2018, p. 96)

The language of the Anthropocene that has emerged over the past decade has several problematic aspects. First, it is used by those environmentally concerned, particularly with climate change, in a negative sense: there is nothing that is left untouched by human hands. At the same time, it is positively used by some transhumanists: the era of the human has arrived and we have gained the upper hand over nature. This is the first named geological era that has resituated the human as the locus of geological time and it is emotionally charged, rather than descriptive. Is this not just a re-staging of anthropocentrism in new clothes: whether we take it to be a positive or negative thing?

Second and related, the Anthropocene leaves humans with too much control. We are so powerful that we have brought about a new geological era, so why not geo-engineer the world further to create a different era? This is the hope of some transhumanists, who are frankly happy that humans are becoming more silicon, metallic and technological than flesh, tissue, and biologically rooted. In other words, is this not the era of the Anthropocene announcing that we have subsumed nature under human control? If this is the case then perhaps we just need more human technologies and engineering to "fix" the problems of climate change.

Third, the Anthropocene lumps all humans together as if there is equal responsibility for climate change across the globe. This is convenient nomenclature at a time when it has become clear that the fossil-fueled northern hemisphere (for the most part) is largely to blame for the current climate crisis. Not all people are equally responsible for mass extinctions, coral bleaching, and climate change. For this reason, some have argued that we call this era the capitolocene (though others point out that communism has not done better environmentally or socially). Others have argued that we name this period the fossil-fueled era (Moore 2016). In any event, the nomenclature "Anthropocene" 
levels humanity in a way that makes it easy for first world leaders to take issue with African, Latin American, South Asian, and South East Asian countries who argue that they were not the one's primarily responsible for resource extraction and thus, should not have to pay as much as wealthy countries in terms of mitigation and adaptation costs.

The leveling of humans to a common anthropos along with the perpetuation of the idea of human exceptionalism and/or anthropocentrism are, to say the least, problematic. When humanity is made "one," the most powerful among humans define what the normative human is: the colonizing subject rears its ugly head. From the perspective of the colonizing subject, humans ought to have the agency and certainty through science and technology to solve all social and ecological problems. Those human subjects who fail at this (for lack of resources due to various oppressions) are seen as less than, dangerous, criminal, pitiable, or as charity cases by those who most match up to the ideal colonizing subject. Furthermore, those who base knowledge claims outside of modern western modes of knowledge (reason, objectivity, science, and still sometimes Christianity) are seen as in need of education, enlightenment or development. Polytheists, Muslims, animists, and "others," that fall outside the single tunnel of western Modernity must all be ranked as less than the western modern (Mignolo 2011).

From this anthropic, modern, certain perspective, there is no need for faith and hope: the certainty of Modernity does not require it. The certainty of Modernity requires only that everyone and everything comply or consent to its logic. What if, instead of projecting this certainty onto an indefinite future in which the anthropos will be at the center, we begin to live once again in hope and faith toward something different? What if, instead of recreating the world for the anthropos thorough technologies of certainty, we develop instead uncertain technologies for the entire planetary community? Instead of using science, technology, and religion to create the world in the image of a certain ideal of humanity, what if we used science, technology and religion to co-create a flourishing and more just planetary community?

As the epigram to this article suggests, maybe the fact that we are here has nothing to do with telos or foundations laid down "in the beginning". Instead, maybe it is a game of "chance and skill" played with the evolving planetary community. From this latter perspective, it may be possible to live in faith and hope with the planetary community for a more just and flourishing future. In this brief article, I describe some of what I call the technologies of certainty and how these technologies of certainty create violence to earth bodies (human and non). These are essentially the tools of western colonization used by the Greeks/Romans, Christians, and then the proponents of European western Enlightenment. These are all technologies of certainty that maintain the center of power for the status quo. In the second part of this article, I describe technologies for what I am calling a Critical Planetary Romanticism (CPR) for planet Earth. These technologies emerge from and hold open spaces of uncertainty, spaces of otherness, spaces for new possibilities to emerge. It is from these spaces and with these technologies that I think hope and faith for a more just, equitable, and flourishing planetary future might emerge.

Before I begin with these two main sketches of the technologies of certainty and uncertainty, I start with a narrative that locates my own subjectivity. This narrative approach is important because narratives allow people to make connections (intellectually, personally, and affectively) in ways that trip up the idea that ideas and knowledge are merely objective, linear, rational, and logical. So, I begin here with my own eco-socio-cultural location to help attune the reader to my arguments.

\section{From Uncertainty to Certainty: The Story of One Family Farm}

Figure 1 is my family's old farm. I lived in that little house in the front left corner as a baby and I grew up playing on that farm, helping out with our family garden plot, shucking corn and hulling peas, riding in combines with my grandfather, and hunting and fishing in many different wooded areas and reservoirs that made up that unique landscape. All of this gave me embodied knowledge about human-earth relations: predator-prey relations, the importance of "listening" to the land, the type of "balance" that one had to make in terms of how much land should be under production at any given 
time, etc. It also gave me a sense of what it meant to live in faith and hope. Every year, farmers take out loans for the crop they are putting in the ground in hopes that the yield will be enough to make a profit. This is not guaranteed, and it takes the cooperation of many different entities within the natural world to make it happen. This cooperation-between humans and the rest of the natural world-was something that was always open-ended (never certain). Furthermore, we were a part of this unique landscape and ecosystem. Nature was, then, never for me a wilderness devoid of human life, nor was it just a mere resource for human projects: rather, we are a part of nature and whatever culture, language, and human knowledge and technologies are, I grew to understand them as part of nature as well.

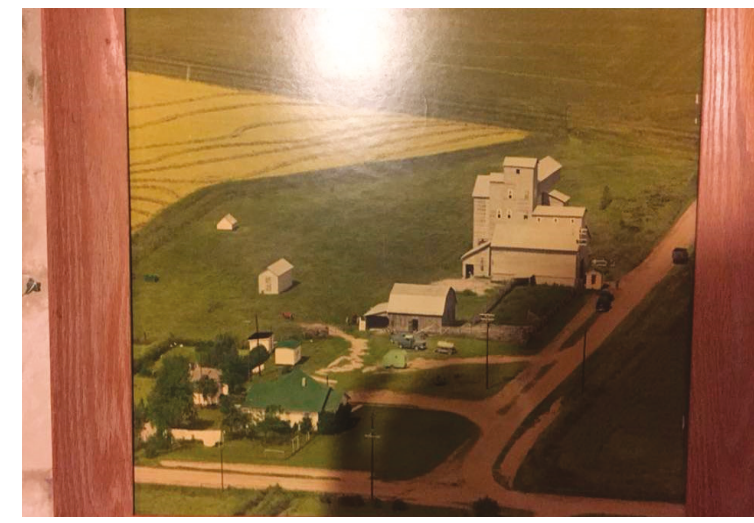

Figure 1. The Goodwin-Bauman Family Farm.

During the 1980s as some readers will recall, the deregulation by the Reagan administration put huge strains on smaller family farms like ours. Under economic pressures, I watched over a period of 10 to 15 years as this farm changed from a multiple-use farm (hunting, fishing, rotating crops of corn, soy, rice, sunflowers, and milo, mostly, along with areas for family garden plots) to mono-cropped Monsanto soybeans. The forested areas where we went hunting were cut down for more production area, and the reservoirs were not maintained as an ecosystem (with a focus on game and wildlife) but were turned into mere sources of water for the crops. This is an example of the reductive-productive model that I critique in this article, along with its underlying assumptions about truth, nature, and the role of human beings on the planet. The transformation of my family farm by this reductive and productive model is a microcosmic experience of what living in the Anthropocene is like. I will come back to this personal story at the end of this article. Here, I start describing some technologies of the reductive-productive model that I think are imported into the modern scientific narrative from its roots in monotheism, and especially Christian theology: chronological time, an understanding of causality as efficient, and human exceptionalism.

\section{Technologies of Certainty (Nationalism/Neoliberal Globalization): The Mechanized Organism (Enframement)}

When I use the word "technology" throughout this article, I mean it in the broader Ancient Greek sense, which can mean language, ideas, art, and anything that helps shape the material world around us. Accordingly, I include religious ideas here. Technology is, in this sense, part of being human. Technology is not limited to human persons, but human persons seem to rely on it to inhabit the world to a greater extent than any other persons or beings on the planet that we know of (for better and for worse). Technologies in this broad sense shape the becoming of earth bodies in different ways (both good and bad). Here, I examine three of the technologies that have helped to create the mechanized organism that we now call "The Anthropocene": chronological time, the reduction of causality to efficient causality (which is another way to talk about isolated agency), and essentialism (which 
supports human exceptionalism to the rest of the natural world). These are not the only technologies I could refer to, but they are important ones.

\subsection{Chronological Time: The Fossil Fueled Tunnel of Time}

Chronological time produces anxiety because it places all of our thinking into an abstract sense that is literally "out of this world" and "out of this universe." Chronological time, an abstraction, becomes more important than immediate and present relationships and our embodiments in the world. In a world sped up by fossil fuels, the abstraction of time creates a pace of progress that far outstrips the regenerative capacities of the planet, which evolved at their own pace and have no regard for our abstractions. The pace of contemporary, industrialized life has helped to create the problems of climate change, of resource extraction, of extinction. They have taken human lives away from the bubbling present in order to build an imagined, transcendent future (Bauman and O'Brien 2019, p. 112).

This chronological time when projected backwards onto history from the perspective of the colonizer creates a tunnel of time. This tunnel imposes a colonial narrative on the face of the planet that moves from the Ancient Greeks, through the dark ages, and into the European Renaissance, the discovery of "America", the American Frontier, and now I would say into the Elon Musks of today, that fuel the technological and space exploration necessary for some humans to leave this planet behind. All other narratives and events must be incorporated into or effectively erased from this narrative (like the dark ages which cover over the Arabic/Muslim influences of the rise of modern science; the erasure of indigenous peoples through slavery, forced migration, genocide, and taking over of their lands under the banner of "terra nullius", or the "Orientalism" that sees East, Southeast, and South Asia as resources for invigorating the continuation of the euro-western narrative) (Mignolo 1995). The discourse of the pre-modern, modern, and post-modern also continues this narrative, which is precisely why I attempt to articulate an alternative in the form of a critical planetary romanticism for the Earth.

The tunnel of time also underwrites the narratives of evolution that place Europeans at the "top" of the evolutionary ladder, and the anthropic narratives of the universe that suggest that humans are the most complex creatures in all the universe. From this perspective, the 13.8 billion year process of cosmic expansion has been about us (Sideris 2017). This "tunnel of time" is the result of looking back into history from a presentist perspective and re-narrating everything up to one's own culturally, socially, biologically located point. One is more or less successful at containing all histories under one narrative, the closer s/he is to the center's definition of "the norm." In other words, those that have more power in the globalized world, have more power to reinforce their narrative across the face of the globe. This is the violence of the "tunnel of time".

Teresa Brennan's book Globalization and its Horrors: Daily life in the West describes this tunnel of time (Brennan 2003), and how since the "great acceleration" of WWII (or the increase in speed of the technologies of production, communication and transportation through fossil fuels), this time is outstripping the regenerative capacities of the planetary community (McNeill and Engelke 2014). In other words, the tunnel of chronological time is now so sped up-think flying, cell phones, instant information through the internet—-that just by living our daily lives, we are living outside and beyond the times of the planet. What does it mean that 100 years ago, most people's lives were limited by travel and information to a smaller space and fewer possibilities, as compared with today when more and more people are "urban" and have more access to information, possibilities, and moving about the planet? Does this time propel even our hopes and dreams beyond the carrying capacity of the planet? What are the effects of this tunnel of time on the planet and the different bodies therein? Such questions take time to answer and require a complexity that the "tunnel of time" will not allow for. Perhaps this slowed down time of the current global pandemic will give space for slowing down to think about the pace of daily life in Modernity. The tunnel time, Chronos, pairs well with and depends upon an understanding of efficient causality (not complex causality), and humans as the only real agents on the planet. 


\subsection{Efficient Causality: Isolated Agency}

Aristotle proposed four different types of causality—material, efficient, formal and final—and these were largely narrowed to one through the long, ongoing processes creating the Mechanized Organism and the reductive productive model of science. Efficiency isolates agency to the individual, and is much faster, cleaner and easier than looking at the more diffuse causality found in its formal and final senses. Everything must be assessed, measured, and have specific, efficient outcomes that lead to technology transfer and economic gain. This type of causality is largely what also gives us our sense of individual responsibility that is at the heart of Lockean Liberal economics and our legal systems in the US. In Locke's first Treatise, there is a long exegesis of the Genesis 1 narrative that focuses on what the imago Dei means. This was the period of the Glorious Revolution, and Locke was arguing against Robert Filmer, who interpreted the Genesis narrative as supporting monarchy. For Locke, instead, it meant that each and every individual has the essential right to be self-directed, we are all, in a sense "little gods" or little monarchs (Bauman 2009). Though Locke challenged the social system of monarchy and argued for rule by the people, he failed to critique the anthropology behind monarchy, that of the power-filled, isolated individual (which in turn has links with the omni-God who creates ex nihilo). Instead, everyone becomes their own little monarch. With our own isolated agency, we can then turn "dead, empty matter" into useful private property by mixing it with our labor. This making of matter dead, and humans as agents, requires a type of human essentialism. Locke thought that most people - women, black slaves, native peoples—should be counted in the category of human, except for those who were atheists-presumably because the foundation for the isolated, agency filled, individual is a creator deity. This type of essentialism denies some persons of humanity, while creating a boundary that also justifies human exceptionalism. The boundary between human and animal is policed both on the human side (through excluding some humans) and on the animal side (claiming that language, technology, or something else is reserved for only humans) through the logic of essentialism and exceptionalism. This is evident in terms of what counts as "nature" in modern thought.

\subsection{Essentialism and Exceptionalism: Humans as the Only Agents that Matter}

What do you think of when you think of "nature"? That is the question I ask my undergraduate students on the first day of the semester every time I teach my "Earth Ethics" course. Invariably, I get similar answers from my students: blue skies, whales, the ocean, trees, animals, wilderness. Very rarely do I get human beings, and almost never technology and the very buildings we live in. This is human exceptionalism. If we and our technologies are not of nature, then are we aliens? The driving question of the course is: how have we thought and felt and hoped our ways out of the rest of the planetary community, and how might we think, feel and hope ourselves back in?

There is a two-part process on the road to human exceptionalism: first you have to make a delineation between humans and non-humans (as mentioned above). The now infamous critique by historian of science and environmental historian Lynn White Jr. argued that the idea of "human dominion" in Genesis was to blame for human exceptionalism in the western world (White 1967); that same Genesis narrative that Locke used to justify individual private property, which I spoke of above. The last 50 years of the field of "Religion and Ecology" has rendered White's reading more complicated and complex, but the basic idea still remains. Whether it is the imago Dei, Reason, the Cogito, the capacity for language, technology use, self-reflexive consciousness, or the capacity for religious experiences, many scientists, philosophers, and theologians have tried to consistently maintain the uniqueness and specialness of human beings through an essence that makes us different from the rest (Peterson 2001).

The second part of human exceptionalism is then the demotion of all else toward human ends. This is what Val Plumwood calls "ethical" anthropocentrism (Plumwood 2002). Plumwood argues that we should all admit to being epistemically anthropocentric: we are embodied humans and can only see the worlds in which we live from that perspective. However, this epistemic location does not have to mean "ethical" anthropocentrism, which is rating all reality by whether or not it is beneficial or 
useful to human beings. It is this latter bit that suggests all things must fit into human history, and even then into western Modernity's version of history. It is this ethical anthropocentrism that suggests the rest of the natural world is "standing reserve" for efficient use toward human ends (Heidegger 1976).

With the technologies of, chronological time, efficient causality, and human exceptionalism, the world is created toward human ends; well, at least some humans' ends. The enlightenment, civilizing mission, cultivation of "empty" lands, and economic development are all narratives that use these technologies to recreate the world into a specific image, and to a large extent ignore the problems and violence that this re-creation causes. This vision requires no hope or faith, because it is the only path forward from the present. Except it is no longer viable. Fewer and fewer people benefit from this vision and those abjected by it and those who suffer by it are making their voices known. The rhetoric against the $1 \%$ is a testament to this unrest. Furthermore, climate change is a result of this fossil-fueled understanding of time (and corresponding technologies of human exceptionalism). As more and more begin to experience the effects of mass economic inequity and climate change, this narrative sews more and more doubt, and people begin hoping for a viable alternative that is better for the planetary community. I argue that we need new technologies that will bring about a more flourishing and a more equitable and just planetary future.

\section{Technologies of Faith and Ambiguity for the Planetary: The Organismal Machine (Poiesis)}

Perhaps a "silver lining" of climate change and the social and environmental problems we are facing in this era of climate change and neo-liberal globalization is that, like the ouroboros, the Anthopos and its Antrhopocene is devouring its own tail, creating chaos all around. This may not seem like a silver lining at all, but it may also lead to the recognition of our planetary embededdness. We are not in control; we are parts of a larger, open, indeterminate and ever-evolving complex planetary community. And, we do not know what to do. We may know some things not to do, but no one knows what lurks around the next IPCC report, or how any given action will ripple out into unknown consequences. We must, as Donna Haraway argues, stay with the trouble (Haraway 2016).

These conditions of uncertainty actually allow for critical faith and critical hope to return to our humanity. Before the universe fizzles out (as in current standard models), and before the sun expands outward and then burns out and burns the earth up along with it, and even before the worst of climate change exacerbates all of our social and ecological ills beyond what we can even imagine now, we are here, and we can still act. Faith and hope have to be about the close up and the near (Latour 2005). Faith and hope must take planetary grounds. There is a sense then, as Kyle Powys Whyte argues, that we have much to learn from those who have already experienced apocalypses (Whyte 2018). Indigenous peoples who have experienced genocide and colonization, or those whose worlds were destroyed by slave trafficking or genocides, these are peoples who have lived through and are living after the apocalypse. How do we create worlds out of the ashes of the old ones? How do we live through what seems like the end of the world? It is, I would argue, partly about doing the palliative care required to put the ailing Mechanical Organism to rest, and figuring out how to be midwives for more Organismal Machines. What might technologies of the planetary, or what we might also call Organismal Machines, even look like? Unlike a mechanical organism, which imposes mechanics upon the planetary systems, an organismal machine, models the planetary systems in order to create planetary technologies.

\subsection{Planetary Times: Reverberation, Spiraling (Queering)}

If the tunnel of time, Chronos, takes us out of our own and other planetary bodies, then perhaps a planetary time should take account of the multiple experiences of the planetary community. One such re-imagining can be found in the speculative scientific idea of "Rainbow Gravity". In this theory, there is no beginning to the universe: no big bang, no creation ex nihilo. Further, there is a kind of particle-based perspectivism according to this theory. As one article puts it, "The color of light is determined by its frequency, and because different frequencies correspond to different energies, light particles (photons) of different colors would travel on slightly different paths through spacetime, according to their energy" 
(Moskowitz 2013). Different frequencies, different paths through spacetime-different embodiments, multiple ways of becoming. This is highly speculative, but speculation is precisely what helps us materialize different ways of becoming. We need different stories about possible beginnings and possible future becomings in order to break out of singular historical narratives. We need spectral thinking in order to discern the spectrum of possibilities. Our seizing of alternative possibilities for how we might want to become as a planetary community must include speculation, or we will be adrift in spacetime unaware of the grounds on which we stand.

Religions are full of examples of different times: meditation, yoga, contemplative, and many mystical practices attempt to get us into a different way of understanding our time that helps slow us down so we might recognize our relatedness to planetary elements and bodies. The ideas of dreamtime or sacred time also have nothing to do with Chronos. Might we also be able to extend these experiences of different times to different entities and organisms? We might talk about the times of trees, of rivers, of bees, or of polar bears; the times of glaciers and whales and sea turtles; the time of the mosquito, the flea, and the nematode. Different bodies in the world demand different times: one size does not fit all.

This understanding of multiple times also implies that there are multiple worldings, together all of which at any moment might make up what we call the open planetary system. It is not closed, and there is not a central world to which all of our worlds are attached, but taking a page out of a modified understanding of perspectivism (Viveiros de Castro 2012), there are many different planetary worlds being co-constructed (human and non), as Latour might argue collected (Latour 2004), at any given moment. It is the sum of these worldings that we might call the planetary. Such an understanding of time also calls for a different understanding of agency and causality.

\subsection{Multiple Causality and Distributed Agency: Formal, Final, Material, Efficient}

If efficient causality helps keep us locked into Liberal understandings of action, and also into a human-centered understanding of agency, then perhaps what is called for from a planetary perspective is distributed agency. Animisms, New Materialisms, and other immanent traditions within religions and newly emerging immanent ways of thinking also suggest this type of distributed agency. These planetary relationalities suggest that the reasons you are reading this article have a lot more to do with other agents and actants than with your own individual decision to do so. The formation of the planet, breathable oxygen, the bacteria and other organisms that make up the microbiomes of our bodies, the evolutionary flows that led to the development of our opposable thumbs, the cerebral cortex, the other flora and fauna we have co-evolved with, the relatively stable climate and related oceanic currents we have experienced over the last 10,000 years that have allowed for human civilizations and all we think of as "culture" to emerge, the time in which we were born, the sex, race, gender, sexuality, economic class, and other identities that are privileged (or not) depending on which societies we come from, the deep affects that structure what we understand as good, true, and beautiful, the languages we are born into and/or learn, the infrastructure that forces how we move energy, materials and information around the planet, the technology that went into my Macbook that produced this article, and the internet without which you probably would not be reading this. These are all agents that make our own agencies possible, narrow our own fields of agency and/or persuade our agencies to choose this or that in any given decision process.

My friend and colleague Mary Keller in her work on "spiritual possession" within Afro-Caribbean religions has developed an understanding of diffused agency that illustrates this way of thinking in regards to climate change (Keller 2019). Instead of thinking that we are in any sort of control to fix the problems we created, she argues that we are all possessed by fossil fuels; climate change is the demon of that possession. We must listen to what this demon is trying to tell us if we are ever going to see the demon leave our bodies. This is a radically different approach to understanding ourselves, one which acknowledges we are not in control. We must appeal to the gods, to ancestors and other ghosts, and to other planetary spirits and creatures in order to get help, in hopes that we might co-create different 
worlds in the planetary future. We have to live without certainty, and instead in the spacetime of planetary faith and hope.

\section{Planetary Creatures, Planetary Citizens, and the Planetary Polis}

As my friend and colleague James Miller often quips in conversations, "It doesn't take a village, it takes a planet to make a person." Coming from his reading of the porous, fluid understanding found in Daoism, he argues, against histories of exceptional thinking, and instead that this planet is not made for us, but rather that it makes us (Miller 2017). We are dependent upon it, not the other way around. Recognition of this deep, planetary dependency is something newly emergent, for we have not lived in this globalized world in which we know so much about the entire planet until very recently. This does not mean there are no other traditions that have focused on this dependency: dependent co-arising in Buddhism, many indigenous animisms and shamanisms, Daoist, and Jain ways of thinking, among many others, have understood this in relationship to the "worlds" those thought systems inhabit, but it is only with the globalized world that we can get the type of understanding that Marcos of the Zapatista Army in Chiapas, Mexico argued for. He argued not for hope of a new world, but to live in a world of worlds (Mignolo 2011). Worlds within worlds, that is the reality of a relational, planetary human in which the human becomes, provincialized. Important to this idea is how these worlds relate and at any given moment that relation makes up what we might call the overall planetary community. There is no single "world," to which these other worlds are fitting into, but the relationships of these worlds, like the microbiomes and ecosystems and climate that make up our own worlds, make up that moment by moment manifestation of the planetary community. My hope is that this from this worlded, grounded understanding, a planetary polis (of sorts) will emerge where we can talk about what types of worlds and what types of planetary communities we want to think and act towards.

The hope here is not a hope that "looks forward" naively from the present. If the opposite of hope and faith is certainty, then a hope that looks forward often uncritically recreates the future from the present and all that goes along with it. "Things will be ok," and "Things will get back to normal" often mean a return to what has already been. If we take Walter Benjamin's metaphor of the Angel of History, facing backwards, being blown into an unknown future, while looking at all the catastrophes that build up in the name of progress, then we might understand hope as a building up of different worlds, from the ashes of the catastrophes of other worlds into an unknown future (Benjamin 2009). From this perspective, hope is an undoing of the violence of the technologies of the mechanistic organism, from within. We need to practice then, what Jack Halberstam calls "The Queer Art of Failure" (Halberstam 2011). If the success of the fossil-fueled system of the Anthropocene, and all the technologies that support it, are the problem, then we need to fail, not be successful. As Ed Abby might say, we need to practice monkey wrenching, to take apart the system from within. This also means paying deep attention to the worlds and all therein that we are losing. Hope is not for the present to be as it is in some sort of future state that is better, but hope for different worlds to come. As Jonathan Franzen wrote in the New Yorker,

Instituting humane immigration policy, advocating for racial and gender equality ... supporting a free and independent press, ridding the country of assault weapons-these are all meaningful climate actions. To survive rising temperatures, every system, whether of the natural world or of the human world, will need to be as strong and healthy as we can make it. (Franzen 2019)

This is the type of faith and hope that is still possible in most of the worlds in which we live. I do think it is, perhaps through these "little moves against destructiveness" (though these are not so little) that we can still hope for a different future to be built out of the ashes and rubble of the Anthropocene (Bedford 2001). 


\section{Coda: From Family Farm to Solar Fields}

Actions that do not seem so obvious or possible from the present moment can emerge in the processes of building different worlds. When I think about growing up on that family farm, as a child, I could have never imagined that it would one day be a solar field (See Figure 2). This is part of what it means to live in faith and hope for a different (and hopefully better) planetary future. This is no return to paradise, nor is it business as usual. It is something different that emerges out of the planetary present. There is technology involved, but it is renewable technology that listens to the demands of those voices who have been destroyed by fossil fuels. It will come with its own problems, such as the destructive mining of lithium needed to power the green, renewable revolution. But, in all this, it is a different possibility for living that may bring about more justice and flourishing for the planetary future. The fact that solar fields exist on a former soybean farm just outside of Stuttgart, Arkansas, (USA) is a major (re)attuning to the world that has taken place in my lifetime. It may be too little too late for many of our extant worlds, but the fact that this former unimaginable has now been made not only possible, but real, gives me faith and hope for a different planetary future.

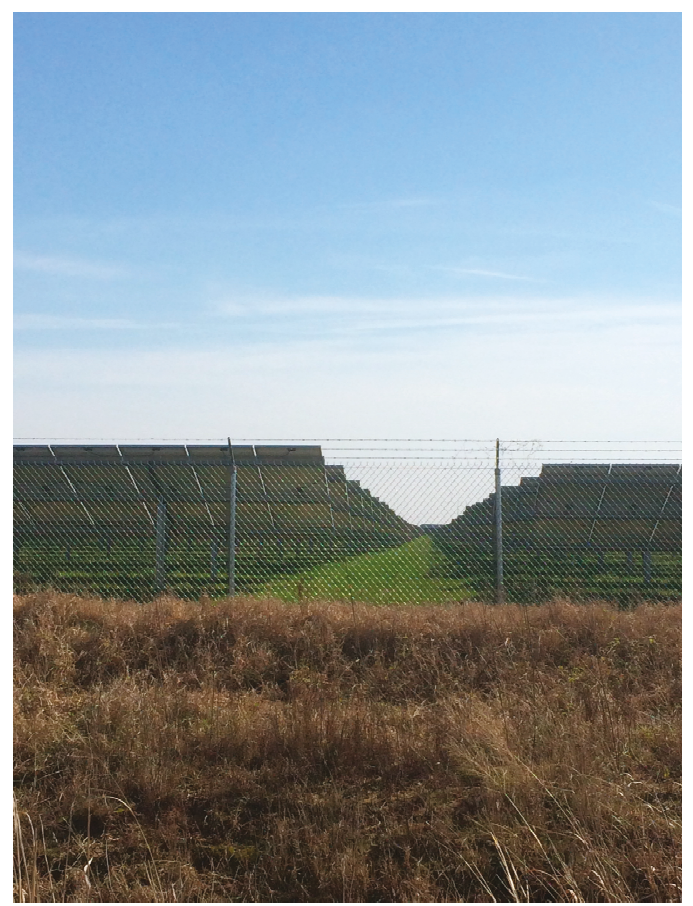

Figure 2. Solar Fields on the former Goodwin-Bauman Farm.

Funding: This research received no external funding.

Conflicts of Interest: The author declares no conflict of interest.

\section{References}

Bauman, Whitney. 2009. Theology, Creation and Environmental Ethics: From Creatio ex Nihilo to Terra Nullius. New York: Routledge.

Bauman, Whitney, and Kevin O'Brien. 2019. Environmental Ethics and Uncertainty: Wrestling with Wicked Problems. New York: Routledge. 
Bedford, Nancy. 2001. Little Moves Against Destructiveness. In Practicing Theology: Beliefs and Practices in Christian Life. Edited by Miroslav Volf and Dorothy Bass. Grand Rapids: Eerdmans, pp. 157-84.

Benjamin, Walter. 2009. On the Concept of History. New York: Classic Books.

Brennan, Teresa. 2003. Globalization and its Terrors: Daily Life in the West. New York: Routledge.

Franzen, Jonathan. 2019. What if We Stopped Pretending. The New Yorker. September 8. Available online: https: //www.newyorker.com/culture/cultural-comment/what-if-we-stopped-pretending (accessed on 3 April 2020).

Halberstam, Jack. 2011. The Queer Art of Failure. Durham: Duke University Press.

Haraway, Donna. 2016. Staying with the Trouble: Making Kin in the Chthulucene. Durham: Duke University Press.

Heidegger, Martin. 1976. The Question Concerning Technology and Other Essays. New York: Harper.

Ivakhiv, Adrian. 2018. Shadowing the Anthropocene: Eco-Realism for Turbulent Times. Earth, Milky Way: Punctum Books.

Keller, Mary. 2019. The Spirit of Climate Change. Paper presented at the International Society for the Study of Religion, Nature and Culture Meeting, University of Cork, Cork, Ireland, June 14.

Latour, Bruno. 2004. The Politics of Nature: How to Bring the Science into Democracy. Cambridge: Harvard University Press.

Latour, Bruno. 2005. Thou Shall Not Freeze-Frame, or How Not to Misunderstand the Science and Religion Debate. In Science, Religion and the Human Experience. Edited by James D. Proctor. Oxford: Oxford University Press, pp. 27-48.

McNeill, John Robert, and Peter Engelke. 2014. The Great Acceleration: An Environmental History of the Anthropocene since 1945. Cambridge: Harvard University Press.

Mignolo, Walter. 1995. The Darker Side of the Renaissance: Literacy, Territoriality, and Colonization. Ann Arbor: University of Michigan Press.

Mignolo, Walter. 2011. The Darker Side of Western Modernity: Global Futures, Decolonial Options. Durham: Duke University Press.

Miller, James. 2017. China's Green Religion: Daoism and the Quest for a Sustainable Future. New York: Columbia University Press.

Moore, Jason. 2016. Anthropocene or Capitalocene?: Nature, History and the Crisis of Capitalism. Oakland: PM Press.

Moskowitz, Clara. 2013. In a 'Rainbow' Universe, Time May Have No Beginnning. The Scientific American. December 9. Available online: https://www.scientificamerican.com/article/rainbow-gravity-universebeginning/ (accessed on 3 April 2020).

Peterson, Anna. 2001. Being Human: Ethics, Environment and Our Place in the World. Berkeley: University of California Press.

Plumwood, Val. 2002. Environmental Culture: The Ecological Crisis of Reason. New York: Routledge.

Sideris, Lisa. 2017. Consecrating Science: Wonder, Knowledge, and the Natural World. Berkeley: University of California Press.

Viveiros de Castro, Edwardo. 2012. Cosmological Perspectivism in Amazonia and Elsewhere. Manchester: HAU.

White, Lynn. 1967. The Historical Roots of Our Ecologic Crisis. Science 155: 1203-7. [CrossRef] [PubMed]

Whyte, Kyle Powys. 2018. Indigenous Science (fiction) for the Anthropocene: Ancestral Dystopias and Fantasies of Climate Crises. Environment and Planning: Nature and Space 1: 224-42. [CrossRef]

(C) 2020 by the author. Licensee MDPI, Basel, Switzerland. This article is an open access article distributed under the terms and conditions of the Creative Commons Attribution (CC BY) license (http://creativecommons.org/licenses/by/4.0/). 
Article

\title{
What Else Is New?: Toward a Postcolonial Christian Theology for the Anthropocene
}

\author{
George B. Handley \\ Department of Comparative Arts and Letters, Brigham Young University, Provo, UT 84602, USA; \\ George_Handley@byu.edu
}

Received: 10 March 2020; Accepted: 27 April 2020; Published: 1 May 2020

\begin{abstract}
Although there are many reasons for Christian skepticism regarding climate change, one reason is theological in nature, and therefore, requires a theological solution. This essay explains the theological grounds for climate change denial and for a compromised understanding of the power and creativity of human agency. Drawing inspiration from the ecotheological implications of postcolonial poetics, it seeks to offer revised conceptions of the atonement and the fall and of what it means to read both scripture and nature. The aim is to offer a more resilient Christian theology that can inspire agential creativity in the age of the Anthropocene.
\end{abstract}

Keywords: ecotheology; novelty; postcolonial ecocriticism; Derek Walcott; theodicy; poetics; wonder; eschatology; Noah; Adam and Eve

"We can understand nothing about the politics of the last 50 years if we do not put the question of climate change and its denial front and center."

Bruno Latour

Assuming geologists do indeed decide that we have enough evidence in the record to mark a new geological epoch shaped by human activity, the Anthropocene marks a novel turn from the earth's history shaped merely by natural forces to one now shaped also by human agency. It is not news that many conservative Christian communities in the United States have struggled to come to terms with the novelty of climate change. Although much scholarly attention has been given to the psychological, political, and economic grounds for inaction, ${ }^{1}$ less attention has been given to the theological justifications conservative American Christians often invoke for their skepticism. Although such justifications are no doubt often post-hoc and theology alone is unlikely to solve the problem of denial, theology should still be taken seriously, as this essay does, as both an obstacle and a vital potential motivator for action on the climate. Because research shows that appeals to core values can motivate behavioral and attitudinal changes, ${ }^{2}$ the impetus of the work of ecotheology to mine and revise tradition in light of the novelty of climate change is warranted.

In what follows, I will first explain the theological grounds for climate change denial used by conservative American Christians and what I see as a compromised understanding of the power and

1 See for example Living in Denial: Climate Change, Emotions and Everyday Life by (Norgaard 2011) (Boston: MIT Press, 2011), and Merchants of Doubt: How a Handful of Scientists Obscured the Truth on Issues from Tobacco Smoke to Global Warming by (Oreskes and Conway 2010) (London: Bloomsbury Press, 2010).

2 For example, see Influencer: The New Science of Leading Change by (Grenny et al. 2013) (New York: McGraw Hill, 2013). See also (Roser-Renouf et al. 2016). Faith, Morality and the Environment: Portraits of Global Warming's Six Americas, Yale University and George Mason University. New Haven, CT: Yale Program on Climate Change Communication, 2016. They report that "many Americans who are not currently concerned about global warming, nonetheless believe we should care for other people and the environment, but have yet to recognize that reducing global warming will help both. As the majority prefer religious over scientific explanations, a moral perspective on global warming by religious leaders such as Pope Francis may reach segments of the U.S. public that have yet to engage with the issue." (p. 5). 
creativity of human agency. ${ }^{3}$ I contend that this conservative theology is held captive by the conditions of coloniality. For this reason, I will then turn to postcolonial poetics in order to offer a speculative, postcolonial Christian conception of atonement and the fall. In conclusion, I will focus on how such a postcolonial theology might change the way believers read both scripture and nature and liberate the agency needed to respond to the climate crisis. In other words, I seek to offer a more resilient Christian theology that is, I hope, sympathetic to the concerns of skeptics, but that can inspire their agential creativity and novel responses in the age of the Anthropocene.

\section{Novelty, Agency, and Prophecy}

Perhaps the most common and important source of theological resistance cited by American conservative Christians is the idea that the very idea of climate change threatens the absolute sovereignty of God by dangerously and hubristically imagining human power on par with God. Climate change isn't happening, in other words, because theologically it can't. ${ }^{4}$ This raises the question that if more emphasis is placed on the unprecedented novelty of the problem, will traditional cultures feel less likely to believe they can offer a response? Another source of theological resistance is eschatological: If more emphasis is placed on the dire circumstances that lie ahead, will believers in the end times feel obligated to accept decline as inevitable? Meanwhile, climate science uses assessments of past impacts and present patterns in order to describe the novel and potentially catastrophic trajectory of anthropogenic change, and thus, challenges human motivation and our ability to identify the grounds for innovation. In other words, despite the best of intentions, the science that undergirds the Anthropocene presents itself as a kind of fatality or inevitability that competes with Christian eschatology and often inspires indifference, denial, or, worse, theological arguments for its inevitability and necessity.

It should be obvious, however, that a moral response to the novelty of the Anthropocene requires novelty from human beings as geological agents. This would mean that human beings should not only acknowledge that their agency has brought about a change in the earth's history but find ways to use that agency to change it again, hopefully more deliberately, more carefully, and with a better trajectory. Feelings of inevitability and theological or ideological justifications for the status quo cannot produce novel, moral responses. Instead, it seems that all human populations and certainly all Christians need new ways of thinking about the earth, its climate, and its presumed telos that can teach, rather than shield people from, answerability to the world.

As Michael North's important study of novelty has shown, how we imagine that things will end has a lot to do with how we imagine that they began and what we believe are the parameters of human agency. ${ }^{5}$ North identifies a fundamental struggle in Western thought between the idea of a creation that happens ex nihilo and a creation that emerges from pre-existing matter. According to the Greeks, or at least to the atomists who were particularly persuasive to the modern West, "nothing comes from nothing," as Parmenides formulated it. The Roman poet Lucretius popularized Parmenides's idea by suggesting in his poem De Rerum Natura that the world is made up of only one fundamental material and that the world was made various and diverse by virtue of recombinations of this material. As Lucretius argues, "if things came out of nothing, all kinds of things/ Could be produced from all things. Nothing would need a seed" (Lucretius 2008, p. 8). While atomism insisted on continuity, it struggled to account for novelty. The atomists' answer was the idea of the swerve, a way of describing the motion of atoms that defied pure mechanistic or predictable patterns, and that therefore, accounted for the possibility of change and created the space for the possibility of human agency. In such a

3 I do not intend to describe all Christian theology, of course. I am, however, describing a theological argument of denial that is not uncommon among conservative American Christian communities. Rather than rehearse at length my argument I have already made regarding a Christian theology of climate change denial, I refer my reader to my more in-depth exploration in my chapter "Climate Skepticism and Christian Conservatism in the United States," in my co-authored book, Climate Change Skepticism: A Transnational Ecocritical Study, with (Handley 2019) (London: Bloomsbury Books, 2019), pp. 133-73.

4 Among those who have made this argument are James Inhofe, Sarah Palin, Pat Robertson, The Cornwall Alliance, and others.

5 See (North 2013), Novelty: A History of the New (Chicago: University of Chicago Press, 2013). 
cosmos, accident and suffering are central to the fabric of reality; human meaning, although perhaps not obvious, is possible.

Christians, on the other hand, posited a creation ex nihilo which explains novelty and human meaning more overtly by attributing it to the creative energy of God. However, this cosmology also famously created the added difficulty of adequately accounting for accidents, tragedy, and inexplicable and unjustifiable suffering. Theologians went to work on theodicies that would explain the reality of suffering and evil in light of the omni-God's sovereignty, but such explanations often came at the cost of fully accepting the human responsibility and capacity to act to mitigate suffering.

The point of this brief sketch is this: How Western society has thought about continuity and novelty has a great deal to do with how it has thought about accident, tragedy, and the opportunities and responsibilities of human choice. How Christians choose, then, to think through the problems of evil and suffering will likely determine how threatening the reality of climate change is to their cosmology. This is no small problem. Jenkins (2013) has persuasively argued that cultures deny phenomena that are perceived to threaten the very ontology of those cultures. A common response among climate activists to this problem is to believe that data can or should change hearts and minds or that simply shaming skeptical cultures for being on the wrong side of history is enough. A more effective response, however, is not to assume a culture's fixity but instead appeal to its dynamism by identifying ways in which it can reread its own tradition and reimagine itself in the face of the unprecedented. In this sense, the path to hope and faith in the Anthropocene is one of imagination and revision. As North's study shows, novelty always has an ambiguous status, in any case. He argues that it is perhaps best to think of novelty as innovation, which is essentially renewal and reform. ${ }^{6}$ We might think of this as akin to the call of St. Paul to "Conform no longer to the pattern of this present world, but be transformed by the renewal of your minds" (Romans 12:2). New responses to climate change do not require new cultures so much as renewed cultures, re-imagined in light of the unprecedented.

Because of its collective and deep temporal dimensions, anthropogenic climate change challenges Western understandings of human agency. ${ }^{7}$ For Christians, it becomes vital to reimagine human agency in this new context. Perhaps it would help to acknowledge that Christianity has not always successfully reconciled the tension between the freedom of the individual and the range or limits of God's sovereignty. Indeed, even though the Bible suggests that the world ends in a final judgment of human choice, it also suggests, at least for some readers, that God's purposes in human history appear to be met precisely by the collapse of history brought on by human choice. I am suggesting that, given that various strains of Christianity are divided by the endless debates about grace and about the possibility of predestination, the status of human agency in Christianity is at best ambiguous. At times, it seems that agency results in novelty but also in predictability, in consequences for which we are truly accountable but also in consequences that were anticipated and perhaps even willed by a higher power.

This ambiguity is even greater when individual choices are assessed within a larger and more collective temporal frame. Christianity anticipates a retrospective look back on the meaning of human history that sees choice as playing a necessary role in the unfolding of history, and that therefore, significantly compromises, if not proscribes, the human freedom to choose anew. For this reason, Christian skepticism tends to arise around events that, because of their scale, suggest a shape or telos to history that had not been anticipated. At the risk of attributing too much theological seriousness to Oklahoma Senator James Inhofe's climate denial, it is noteworthy how often Inhofe (2012) quotes

6 He writes: "Novelty is supposed to be an ontological possibility, since there is 'first use or discovery,' but its objective status is mysterious enough to be protected by scare quotes. To innovate is, in Latin at any rate, to renew or to reform, not to start over afresh" (p. 3).

7 Various scholars have approached this question, including (Serres 1995) in The Natural Contract, Willis Jenkins in The Future of Ethics, and more recently (Latour 2018) in Down to Earth: Politics in the New Climate Regime. 
God's promise to Noah that he will preserve the seasons as a reason to disbelieve climate science. ${ }^{8}$ For many Christians who find themselves skeptical of the claims of climate science, worrying about the destiny of the planet is terrain normally relegated to divine providence. In its crudest form, the logic of this skepticism implies that we are simply incapable of changing the direction of earth's history and that even if we were, this change would presumably have been anticipated by, and therefore, necessary to God's purposes. If the earth is going to die anyway, the logic goes, why bother taking care of it? Which is another way of asking, why not actively bring it to an end?

We see here a refusal to accept responsibility for, let alone the reality of, consequences that are disproportionate to individual intentions. If I only meant to be of help by driving my son to soccer practice or my neighbor to the hospital, why should my carbon emissions be considered a problem? If fossil fuels brought so much human flourishing to so many for so long, why and how is it now the enemy to that flourishing? These questions amount to a refusal to admit that suffering can result from human ignorance and error or that collective action can create negative consequences that are disproportionate to individual intention. The irony, of course, is that such individualistic resistance to believing in a globally and humanly caused phenomenon like climate change results in an abdication of individual responsibility not just for the planet but for the human family. It is as if Christian skeptics, in their anxieties about the weight of human freedom, want to protect themselves and their Creator from the shame of the Creation. Because human freedom means that we can introduce novelty into the world, theology in the Anthropocene, then, ought to be focused on liberating human agency in the face of what appears to be inevitable. Christian theologies will need, in other words, a more adequate theodicy that accepts answerability and inspires love in the face of collectively created and unprecedented circumstances of human and natural suffering. ${ }^{9}$

Instead, we find a form of denial that Bruno Latour argues scales back the interdependency of a global and ecological community and insists on the exceptional and singular character of local identity: "[T]he choice to be made is between a narrow definition of social ties making up a society, and a wider definition of association that make up what have been called collectives" (Latour 2018, p. 57). For Latour, elites shield themselves from the problems of climate change by no longer "pretending, even in their dreams, to share the earth with the rest of the world" (p. 19). And yet who but elites have accelerated the very globalization of the world that they then resent?

In this sense, climate change denial exhibits colonialism's tendency to extend homogeneity across space, as well as to retreat in horror at the diversity thereby discovered. More properly said, we can read climate change denial as a form of neo-colonialism. As scholars such as Richard Grove and Alfred Crosby have well documented, Western colonial expansion inaugurated a new era of globalized ecologies, expansive regimes of invasive species, and an intensified interest in world biota that sought to document the biodiversity of a planet even as that expansion rendered it less diverse. ${ }^{10}$ The Anthropocene is not easily disassociated from the history of colonialism that expanded the reach of capitalism into new corners of the earth and converted people and places into commodities and markets and then ravaged the peoples, cultures, and biodiversity of those places by seeking to remake them in the image of the empire. Ironically, colonialism expanded human understanding of the diversity of the human species but also of the biodiversity of the planet, even as it was shrinking the planet under the

8 In his book, The Greatest Hoax, he writes: "In the end, through all the hysteria, all the fear and all the phony science, what global warming alarmists have often forgotten is that God is still up there and as Genesis 8:22 reminds us: 'As long as the earth remains,/there will be springtime and harvest,/cold and heat, winter and summer,/day and night" (p. 175).

9 I have in mind the kind of theological confrontations with the implications of chance and suffering in evolution that we see in (Johnson 2014) Ask the Beasts: Darwin and the God of Love: "Theologically, [plants and animals] are the work of the Spirit of God who vivifies the community of creation from which we humans have also emerged. The ineffable holy mystery of Love creates, indwells, and empowers plants and animals, delights in their beautiful, wise, and funny ways and grieves their sufferings" (p. 284).

10 See (Grove 1996) and (Crosby 2015). 
reach of globalization and destroying the diversity it encountered. ${ }^{11}$ Colonialism manifested, in other words, a simultaneous fascination with (and repulsion of) the diversity that colonialism laid bare, and generated a cosmology and theodicy that justified, and sacralized, its consequences.

\section{The Lessons of Postcolonial Literature}

These parallels between colonialism and climate skepticism briefly sketched out here justify looking at postcolonial literature for its theological wisdom. I would argue that postcolonial literature is invested in theology, because at the very least, it is invested in rewriting the quasi-theological narratives of inevitability that were offered by colonial centers of power. Like a creation out of unorganized matter, postcolonial cultures must make themselves out of the materials of pre-existing cultural inheritances; they do not have the luxury of pretending to a radical origin. In this effort, they also offer insights into the challenge of identifying the terms of novelty available in light of the previously inaugurated and ongoing catastrophe. The following brief example from the Caribbean demonstrates this.

In 1974, the Caribbean poet, Derek Walcott, wrote an extraordinary essay entitled "The Muse of History" that was a call to his compatriots in nations of the Americas affected by the history of colonialism and the slave trade to find a way to avoid the snares of either the desire for revenge, on the one hand, or an endless nostalgia, on the other. He was concerned that if poets in the New World merely reacted to the forces of colonial catastrophes and were not seizing upon their own powers of imagination and creativity to reorder the meaning of experience and make the world new again, they would fail to escape the imprisoning logic of colonial catastrophes. Poiesis is, after all, a word that suggests a made or imagined new world, and as such, and in a postcolonial context it argues for a space of freedom for the human imagination even in the wake of the particularly egregious and violent history of slavery. For Walcott, post-slavery circumstances make poetry not only possible but necessary.

The challenge that Walcott and his compatriots faced was to make a new world-to find sufficient hope to imagine and create the new-without erasing the traces of what had come before or perpetuating their legacies. Any poet writing in the wake of colonial catastrophe faces the challenge of deciding what should be remembered and why and in what language. Walcott calls for a "tough aesthetic" which "neither explains nor forgives history .... [that] refuses to recognize it as a creative or culpable force" (Walcott 1998, p. 37). I argued in my book, New World Poetics, that this "tough aesthetic" offers a postcolonial environmental ethic because it refuses to make the history of what has happened a prophetic force for what will yet happen. Instead, it places the freedom to imagine history anew squarely on the shoulders of the poet who, Walcott argues, must draw inspiration from the particular gifts of the present landscape. ${ }^{12}$ If the poet believes that nature offers an escape from the nightmares of history, nature will have been reduced to a fantasy, but if the poet is always "wailing by strange waters for a lost home" and bemoaning pre-existing tragedy, the poet will similarly turn away from the present and local environment which holds the key to making a new home in a renewed world (p. 44).

Even though colonial history has indelibly shaped the present, including the colonized and anthropogenic landscape, Walcott insists that nature and the human imagination both have the capacity to remake the meaning of what has undeniably happened and thereby point the way to a new future. Poetic novelty does not come from a separation or rejection of what came before but from a refashioned experience of the ordinary and already known world, as if it were new. This "as if" construction is important to his argument. The figural phrasing of "as if" implies a performance that sees the dramatic irony of its stance of novelty in light of the inherited past. His "tough aesthetic" is not that of Adamic innocence but more like, as he puts it, the self-conscious performance of a "second Adam" in "a second Eden" (pp. 40-41). This leads to an important redefinition of novelty. He explains:

11 I have written elsewhere more extensively about the racial aspects of this phenomenon in my study of interracial sex and genealogy in (Handley 2000).

12 (Handley 2007). 
The Caribbean sensibility is not marinated in the past. It is not exhausted. It is new. But it is its complexities, not its historically explained simplicities, which is new ... while many critics of contemporary Commonwealth verse reject imitation, the basis of the tradition, for originality, the false basis of innovation, they represent eventually the old patronized attitude adapted to contemporaneous politics, for their demand for naturalness, novelty, originality, or truth is again based on preconceptions of behavior.

(Walcott 1998, p. 54)

Note here that imitation does not have to mean derivation just as originality does not require rejection of imitation. Novelty, in this model, is more akin to Lucretius's idea of the swerve or North's notion of innovation; it is the result of recombinations of unchangeable facts that nevertheless propel perpetual change. Walcott is not looking for radical originality but a potent and truly poetic or world-making recombination of inherited elements in order to begin again.

Noah, often referred to as a second Adam in biblical scholarship, might help illuminate the theological implications of Walcott's idea. Noah begins not from a blank slate but from an awareness of extraordinary suffering and even apocalyptic devastation, but begin he must. (It is also worth mentioning that Christ is also referred to as the second Adam, a point I will return to later). Darren Aronofsky's (Aronofsky 2014) 2014 film, Noah, for example, is inspired by Elie Wiesel's notion of Noah as suffering from a form of survivor's guilt (Wiesel 1984). For Aronofsky, the catastrophe Noah has survived is our long history of environmental and social degradations that began with Cain and Abel, and has culminated in an equally unspeakable destruction of human and natural life in a global flood (the allusion to climate change is not lost on the viewer). ${ }^{13}$ Noah's postdiluvian awe, unlike Adam's, is not naïve or ignorant but rises to Walcott's standard of a "tough aesthetic" that can still find a reason to praise existence in the wake of destruction, in part because he can appreciate more fully the potency and irony of natural regeneration. As Walcott explains, for the Adam in the Americas after colonialism and slavery, "the apples of [his] second Eden have the tartness of experience. In such poetry, there is a bitter memory and it is the bitterness that dries last on the tongue" (Walcott 1998, p. 41).

Cultures, of course, are shaped by the accidents of history, but Walcott is suggesting that culture's vitality is found in the creative recombinations of the past that artists make in the present, not in the genetic heritage of historical experience. As Walcott once provocatively said, "history is irrelevant, not because it is not being created, or because it was sordid; but because it has never mattered, what has mattered is the loss of history, the amnesia of the races, what has become necessary is imagination, imagination as necessity, as invention" (Walcott 1974, p. 53). William Carlos Williams anticipated Walcott's postcolonial poetics by once arguing passionately on behalf of poetry's capacity to avoid the traps of historical thinking that only wants to see "generic patterns" in the past, as if all we want or can see are dead people, when it is poetry that can envision our presence among the once-living or their presence among us. ${ }^{14}$ This postcolonial poetics suggests that culture is by default a form of novelty, even if it appears paradoxically as continuity. Akin to Latour's understanding of the protectionism of climate denial, anxiety about the preservation of tradition, or about the loss of such, blunts our capacity to creatively and morally redirect culture.

13 I have written more extensively about this film in my article, "The Anthropocene and the Postsecularity of the Environmental Humanities: Aronofsky's 'Noah'" in Modern Fiction Studies 64: 617-38 (Handley 2018).

14 Williams said, "History follows governments and never men. It portrays us in generic patterns, like effigies or the carvings on sarcophagi, which say nothing save, of such and such a man, that he is dead. That's history. It is concerned only with one thing: to say everything is dead. [ ... ] Not at all. History must stay open, it is all humanity. Are lives to be twisted forcibly about events, the mere accidents of geography and climate? ... If history could be that which annihilated all memory of past things from our minds it would be a useful tyranny" (Williams 1956, pp. 188-89). 


\section{Postcolonial Poetics as Ecotheology}

As is implied throughout this essay, environmentalists have struggled to make a case for hope and to motivate those who remain indifferent or entrenched in denial. They have expended a great deal of energy describing the inaugurated and worsening apocalypse and have tried to shame those on the wrong side of history, but this seems to have only emboldened the resistance. The anxiety of climate activists, however, is that if they speak of hope, they will enable the naivete and denial that they so harshly criticize. There is no doubt that false hopes are to be avoided, but it might help to remember that real hope is a form of moral courage in light of a present challenging reality. A theology that cannot inspire faith in the creative and innovative energy of moral imagination to forge different future risks proscribing change; in other words, it risks caving to the power of a declensionist narrative of forecasted and unavoidable catastrophe. As an alternative, I wish to offer below a speculative proposal for a theology of atonement that resembles this postcolonial poetics of the "second Adam", and that might better serve to liberate Christian agency rather than harden resistance in the Anthropocene.

Christianity faiths posit that Jesus Christ is the means by which humans can find the courage to choose a future different from the one predicted by their past mistakes. Although the atonement means that God will remember human sins no more, that is not the same thing as saying that it erases the fact of what has transpired. Christ's power is believed to be found in his healing and annealing effects, in his capacity to transform the meaning but not the fact of what has happened in this mortal and earthly context. As St. Paul suggests, believers become new creatures in Christ, and this new creation is at least one reason why Christ becomes the Second Adam. New creatures in Christ are not new people with entirely new life stories, but rather people renewed and restored to a proper understanding of themselves, freed to imagine a different future. Like Jesus's wounds, the scars remain, the past has irrevocably shaped the present, but the evidence of such shaping is now transformed into a cause for hope, rather than despair. Whether on the societal or individual level, it seems that the fact that Jesus offers freedom from the nightmare of human sins and lived experience in the body and on this earth does not mean that human sins in this life didn't happen and didn't shape our lives or the lives of other people. What it does mean is that Christ's mercy frees humans to no longer feel determined by the factness of events, to no longer be trapped by a pattern of predictable error.

So what allows life to feel new isn't that the slate has been wiped clean but that human beings have become free to imagine and choose a different future than what seemed to be predicted by their past. Believers could then see with compassion their own living humanity and that of others. We could argue, then, for an atonement that is meant to break the addiction to history and its tone of fatality without jumping the ship, as it were, of life on this planet. Rather than a transformation of facts, the atonement here performs a transformation of consciousness that then changes the meaning of what this life brings, which is perhaps why St. Paul speaks of hope not as the denial of fault, but as its transformation: "My grace is sufficient for thee", the Lord tells him, "for my strength is made perfect in weakness" (2 Corinthians 12:9). Paul responds: "Most gladly therefore will I glory in my infirmities ... f for when I am weak, then I am strong" (2 Corinthians 12: 9-10).

I want to suggest the parallels between this conception of atonement and postcolonial poetics. For example, Octavio Paz eloquently describes the Mexican artist's task in the face of the nation's history of violent rape and destruction in a way that resembles both Walcott's and Williams's arguments about poetry: "History has the cruel reality of a nightmare, and the grandeur of man consists in his making beautiful and lasting works out of the real substance of that nightmare. . . in freeing ourselves from the shapeless horror of reality—if only for an instant-by means of creation" (Paz 1985, p. 104). Paz describes art's power to create novelty in the wake of disaster but from the very materials of what has happened. This is not an oblivious Adamic innocence, but like a second-Adam or Noah, it is a sobered reckoning and transformation of the past through the novelty of imagination and creation. We can see similar atoning language in the conclusion of Walcott's marvelous essay: 
You were when you acted your roles, your given, historical roles of slave seller and slave buyer, men acting as men, and also you, father in the filth-ridden gut of the slave ship, to you they were also men, acting as men, your fellowman and tribesman not moved or hovering with hesitation about your common race any longer than my other bastard ancestor hovered over his whip, but to you, inwardly forgiven grandfathers, I, like the more honest of my race, give a strange thanks. I give the strange and bitter and yet ennobling thanks for the monumental groaning and soldering of two great worlds, like the halves of a fruit seamed by its own bitter juice, that exiled from your own Edens you have placed me in the wonder of another, and that was my inheritance and your gift.

(Walcott 1998, p. 64)

This "new world" that Walcott enters is made possible by his power of reimagining the meaning of the past, which, like grace, allows him to let go of the need for balancing the scales of justice. It might be enough to say that his poetics makes grace and imagination synonymous. Novelty, in this way, becomes a gift of accepting one's inheritance without being determined by it. This "new world" is both a continuation of the old and a yet a vital departure from its devastating impact. In theological terms, we might say that this offers a conception of heaven that is not so much an escape from the conditions of this life but a transformation of their meaning.

\section{Practical Implications}

What might this kind of theology mean in practice? Essentially, I believe it highlights two things: It highlights the poetics of reading — that is, that re-reading is central to remaking a tradition's meaning — and the poetics of landscape — that is, that seeing this ordinary and damaged world with new eyes of appreciation can inspire care, preservation, and where necessary, restoration.

First, let us think about the poetics of reading. If Christian anti-environmentalism has painted itself into a corner of inaction, this is largely the result of readings that assume a reader who is uninvolved not only in the ongoing creation of the world but in the creation of theological meaning itself, that is otherwise fixed and already given. And there are at least three fixed meanings associated with the creation that remain dogma and suggest no significant ongoing role for human agency in the creation. I am thinking of three specific problems: (1) The Creation is read as a one-time event that brought all matter into existence out of nothing by the hand of God who alone possesses the power of novelty; (2) the fall is an unfortunate, even catastrophic, event that has cast us out into a world of matter that is itself fallen and a reminder of our absence from the presence of God, heaven, and our true spiritual nature; and (3) our only obligation to this temporary physical world is to use it for our self-interest. These readings of the Bible have been central to climate skepticism, but they aren't necessary. In the same way that Christ's atonement allows a reconsideration of the meaning of the past, ecotheologians and Pope Francis himself have shown that embracing the freedom and responsibility to reread the Bible and the Creation story is consistent with faithfulness and can lead readers to a new level of understanding of human responsibilities. It would be a mistake, in other words, to always be reading to protect an endangered originary meaning when the goal should be to find contemporary application and relevance. The latter is not inconsistent with tradition but may, in fact, hold the key to its continuing vitality.

What if Christian skeptics questioned the inevitable conclusion or accepted implications of a creation ex nihilo? Lucretius and his atomist predecessors offered an understanding of the origins of matter that turned out to fit more comfortably with the story of evolution than did Christianity. And because it offered an understanding of a world subject to chance, it also more readily understood the reason for evil and suffering in the world. As some ecotheologians, such as Catherine Keller and others have argued, perhaps the biblical account leaves more room for pre-existing chaotic matter than 
was assumed. ${ }^{15}$ And perhaps this matters because it stresses the re-creativity of human agents who participate in and even partner with Creation to remake the world. A creation ex materia feels like a suggestion of a story of nature that does not begin at some radical starting point but is always in media res. While the biblical account of Creation is famously ambiguous, an ex materia understanding of creation is at least more consistent with lived experience of the natural world. While a creation out of nothing preserves the space and power of the divine as the source of all novelty, novelty in the physical world and in culture nevertheless always depends on a re-organization of what comes before. Christians might imagine, then, that even the originary, Adamic language born of awe in the Garden was not new even if its grammar was. The question of the historical status of Adam and Eve doesn't have to be swept aside in order to understand them as always also potent mythological symbols of living human beings that begin not at the beginning of time but here and now. Each believing reader stands like these precursors in the present facing the future, always in the wake of collective and individual histories that haunt the present. Ritual, performance, poetry, and music, as Eliade (1971) has so eloquently argued in The Myth of the Eternal Return, return us again and again to the Adamic moment of Creation, or we might say to the "second Adam" or Noah who always begins again. The ritualistic returns to creation in the arts and in religious practice are ways of suggesting that there is no return to an absolute beginning but instead highlight the perpetual responsibility to reimagine origins so as to refashion moral possibility. This performance of acting as if I were at the beginning of time does not erase the vestiges of the past but is instead a way of imagining what vestiges I am tasting when I taste the world, when I strive to see it with naked and newborn eyes and how I might rearrange those elements through acts of creation into a new world.

In this way, Christians might consider Adam and Eve as caught in a kind of dramatic irony wherein they cannot yet see that the newness around them is a function of a kind of grace-induced forgetting. The old memories have simply gone away. The newness of the world, then, is uncanny, providing echoes of something only vaguely intuited but hinted to have come before. In re-reading the Creation, readers do not go back to the Garden, but they do imagine going back. This is a vital distinction. If readers fail to take responsibility for the imaginative leap that they make in going back to those originary roles of Adam and Eve, they also shield themselves from the roles they play and the damage they do in the contemporary garden of this earth. This shielding is precisely what motivates Carolyn Merchant's warning about the dangerous potential of the Eden myth. ${ }^{16}$ However, what Merchant doesn't adequately account for is the power of the imagination to remake the meaning of such myths. After all, theologians of a Fortunate Fall and artists like Walcott and Aronofsky, as just two examples, are using the myth of the Creation and the fall more ethically and creatively not to justify further exploitation, degradation or mere instrumental use, but rather to inspire new grounds for hope and awe in the wake of catastrophe.

Which brings me to the second practical implication of a postcolonial ecotheology, that of the value of experiencing wonder in this present moment and landscape. Since none of us can go back to a world untouched by human impact, it is tempting to deny that such an impact exists or to wish for transcendence as a form of escape from such conditions. What is needed, however, is a sobered hope. Similar to the spirituality of the second half of life articulated by Richard Rohr, hope in the Anthropocene is a more mature desire for transcendence that is not rebellion, rejection, or denial of what came before but a return that includes but transforms the meaning of the past. ${ }^{17}$ The facts of the Anthropocene can lead to toxic nostalgia, just as they can lead to hardened denial. Since neither is practical or adequate to inspire a different future other than that predestined by the conditions of

15 See (Keller 2003).

16 See (Merchant 2003).

17 See (Rohr 2011). 
history, I am suggesting that intentional re-creations of original myths remind that the imagination is the locus of creative, agential freedom to choose a new future.

Consider, for example, the difference between imagining a present landscape as a static space that is predicted either by God's past creativity or humanity's past depravity as opposed to seeing it as a manifestation of an ongoing creation where God and heaven are immanent, and the future is open. The latter, which we already saw was central to postcolonial poetics, emphasizes human creative capacity and accountability as co-participants in the Creation. This reverses the negative connotations of the Fall-a physical world that is a perpetual reminder of human sinfulness and exile from God's presence-and transforms it into moral opportunity, as a story not yet written by humanity's future choices. The ethical implications of a Fortunate Fall are not unlike those of Epicureanism; a Fortunate Fall suggests that, instead of denying the flesh, deeper joy will be found in the modest management of a pursuit of pleasure, in light of physical and temporal limits. The postcolonial poetics I have described anticipated the criticism of White (1967), and agrees that returning to the inherent value of physical life is vital for Christians to find a way out of the legacies of prior catastrophe.

A Fortunate Fall requires learning to see and accept both the beauty and wonder but also the shame and darkness of ecology. Exotic natural beauty distracts with its marvels and makes the love of nature seem, well, natural, but the true test of that love is how well humans cope with and accept the facts of biological existence-ordinary and dying bodies in ordinary and changing landscapes of home. The mundane and present landscape is a litmus test for one's ability to tolerate mystery and to accept one's mortal createdness. As William Jordan (Jordan 2003) has written, creation is a source of anxiety because it is "troubled, destructive, and shameful" (p. 40). Only in frozen frames of aesthetic beauty does nature seem relentlessly friendly. But Jordan argues that religion must come to terms with the fact that there is "a contradiction inherent in creation" (p. 41). The contradiction includes such facts of nature that new life comes from violence, beauty and ugliness are interdependent, and chaos is inseparable from the order of the Creation. Jordan implies that religion struggles to come to terms with nature because nature is a sign of mortality's injustices of evil and suffering. To confront the complexities of climate change, in sum, Christians need stronger and better theodicies. They need, in other words, stronger grounds for bringing God closer to the messiness of the Creation and made more relevant to human and imperfect responses to it.

Walcott offers some concluding wisdom. Despite a life he often described as weighed down by his own sins and by the sins of history, the immanence of God's glory was central to Walcott's oeuvre. He argued against the tendency to assume that some better world lay across the earth or across the threshold of death and instead brought our focus back to the sights of ordinary light touching upon the familiarity of things and transmuting them into poetic vision. As Walcott (1997) notes in his remarkable poem, The Bounty: "Between the vision of the Tourist Board and the true/Paradise lies the desert where Isaiah's elations/force a rose from the sand" (p. 2). Echoing Leopold's famous call for building roads of receptivity into the still unlovely human mind, Walcott describes an abundant world that only requires the poetic eyes to see it. What blinds the human eye is either worldly hierarchies of beauty that predetermine what is valuable and what isn't or the false religion of believing that paradise is unavailable here and now. What causes the desert to blossom as the rose is a transformation of consciousness, not the act of engineering a garden in the desert or the anticipation of divine intervention that would take us away from this fallen world. Novelty emerges from the capacity and willingness to see the inherent and always available beauty of the earthly desert of this planet, however, compromised by prior human error.

If Walcott's postcolonial poetics is a theology, it is decidedly a theology of a creation ex materia and not ex nihilo, which I am arguing for not so much as a point of doctrine but as an imaginative and poetic practice. It points to a power that respects the contours of a prior reality yet expresses true freedom as it works within the restraints of being. If we are to take this as a theologically serious idea, it suggests that the atonement is more than a redress of the Fall but the very engine of the Creation itself, since it takes up the unorganized pre-existent material of before and shapes it into a hopeful vision of what is 
perpetually yet to come. Artistic creativity is a reminder that human beings participate in their own, potentially atoning and redemptive, way in the ongoing creation of the world. A postcolonial theology for the Anthropocene embraces aesthetic appreciation, the gifts and pleasures of embodiment, and the potency of human agency. This need not inspire indifference in the face of physical suffering. Instead, it could inspire a spirit of reverence for beauty, and a responsiveness to the degradations that have imperiled that beauty.

Walcott wrestled with and decried the environmental degradations of his native island of St. Lucia all of his life, and yet he never felt he was adequate to or able to exhaust its beauty:

yet there are the days

when every street corner rounds itself into

a sunlit surprise, a painting or a phrase,

canoes drawn up by the market, the harbour's blue,

the barracks. So much to do still, all of it praise.

(Walcott 2010, p. 86)

There is an important lesson here the Anthropocene. The Anthropocene demands that humanity faces some ugly facts-not just about nature, but about our own history as a species. But if postcolonial poetics can teach us anything, it is the risk of neglecting the present out of nostalgia for what we have lost. We cannot afford to become addicted to degradation nor even to bemoaning it. For believers, this would mean that the Anthropocene requires human beings to face the Creation with sobered realism and with willed humility and awe. Meeting nature with praise as a divine creation and gift helps to see the condition of embodiment as a blessing rather than as a curse. It begins again the search for new metaphors that might be adequate to the experience of wonder that embodiment inspires. Consider the alternative. Incapable of praise, either because of terror, despair, or indifference, we as a species find ourselves on some kind of downward spiral of inevitable declension. Once Adam and Eve fall, they just keep falling. Once human beings ruin one landscape or one history, they just keep on ruining it again and again, like a dog returning to its vomit.

Too many in the Christian community in the United States continue to sell their theological birthright for a mess of dominionist pottage, falsely assuming that there was something wrong and in need of repair about this world from the moment humans stepped outside of the garden. Christians have been acting as Adam and Eve, over and over again, but in the context of the wrong theology-and the earth's degradations show for it. I say this because they have assumed the world needs redemption through escapist transcendence or through engineered novelty-like some kind of plastic surgery on what they falsely imagine to be the earth's inadequate body, which embarrasses because of its raw asymmetry, lack of proper color, or unruly wildness and incoherence.

Ruination and degradation are undeniably, sobering realities. Carbon emissions that won't leave the atmosphere for hundreds of years challenge the grounds for hope, but fatalism is the curse all Christians must avoid. Novelty based on creative transformation of the conditions of disrepair and despair is what is needed. This is not only indispensable for hope in the Anthropocene but, as I hope I have helped to show, it is, or can be, the very hope of Christian theology. Just as the world needs ecological restoration, I suspect that Christianity faiths need to be restored to their former wisdom, again and again, for adherents to finally awaken and arise to the reality of the world they have inherited. And with each attempt to come to themselves and recall what they have forgotten, perhaps the ruinated world stands a chance to become a new creature too.

Funding: This research received no external funding.

Conflicts of Interest: The author declares no conflict of interest. 


\section{References}

Aronofsky, Darren, dir. 2014. Noah. Hollywood: Paramount Pictures.

Crosby, Alfred W. 2015. Ecological Imperialism: The Biological Expansion of Europe, 900-1900. Cambridge: Cambridge University Press.

Eliade, Mircea. 1971. The Myth of the Eternal Return: Or, Cosmos and History. Princeton: Princeton University Press.

Grenny, Joseph, Kerry Patterson, David Maxfield, Ron McMillan, and Al Switler. 2013. Influencer: The New Science of Leading Change. New York: McGraw Hill.

Grove, Richard H. 1996. Green Imperialism: Colonial Expansion, Tropical Island Edens and the Origins of Environmentalism, 1600-1860. Cambridge: Cambridge University Press.

Handley, George. 2000. Postslavery Literatures of the Americas: Family Portraits in Black and White. Charlottesville: University of Virginia Press.

Handley, George. 2007. New World Poetics: Nature and the Adamic Imagination of Whitman, Neruda, and Walcott. Athens: University of Georgia Press.

Handley, George. 2018. The Anthropocene and the Postsecularity of the Environmental Humanities: Aranofsky's 'Noah'. Modern Fiction Studies 64: 617-38. [CrossRef]

Handley, George. 2019. Climate Skepticism and Christian Conservatism in the United States. In Climate Change Skepticism: A Transnational Ecocritical Study. London: Bloomsbury Academic, pp. 133-73.

Inhofe, James. 2012. The Greatest Hoax. Washington: WND Books.

Jenkins, Willis. 2013. The Future of Ethics: Sustainability, Social Justice, and Religious Creativity. Georgetown: University of Georgetown Press.

Johnson, Elizabeth A. 2014. Ask the Beasts: Darwin and the God of Love. London: Bloomsbury Publishing.

Jordan, William R. 2003. The Sunflower: Ecological Restoration and the New Communion with Nature. Berkeley: University of California Press.

Keller, Catherine. 2003. The Face of the Deep: A Theology of Becoming. New York: Routledge.

Latour, Bruno. 2018. Down to Earth: Politics in the New Climate Regime. Translated by Catherine Porter. Medford: Polity Press.

Lucretius. 2008. On the Nature of the Universe. Translated by Ronald Melville. Oxford: Oxford University Press. Merchant, Carolyn. 2003. The Reinvention of Eden: The Fate of Nature in Western Culture. New York: Routledge.

Norgaard, Kari. 2011. Living in Denial: Climate Change, Emotions and Everyday Life. Boston: MIT Press.

North, Michael. 2013. Novelty: A History of the New. Chicago: University of Chicago Press.

Oreskes, Naomi, and Erik M. Conway. 2010. Merchants of Doubt: How a Handful of Scientists Obscured the Truth on Issues from Tobacco Smoke to Global Warming. London: Bloomsbury Press.

Paz, Octavio. 1985. The Labyrinth of Solitude. Translated by Lysander Kemp, Yara Milos, and Rachel Phillips Belash. New York: Grove Press.

Rohr, Richard. 2011. Falling Upward: A Spirituality for the Two Halves of Life. San Francisco: Jossey-Bass.

Roser-Renouf, Connie, Edward Maibach, Anthony Leiserowitz, Geoff Feinberg, and Seth Rosenthal. 2016. Faith, Morality and the Environment: Portraits of Global Warming's Six Americas, Yale University and George Mason University. New Haven: Yale Program on Climate Change Communication.

Serres, Michel. 1995. The Natural Contract. Translated by Elizabeth MacArthur, and William Paulson. Ann Arbor: The University of Michigan Press.

Walcott, Derek. 1974. The Caribbean: Culture or Mimicry. In Critical Perspectives on Derek Walcott. Edited by Robert Hamner. Pueblo: Passeggiata Press, 1993, pp. 51-57.

Walcott, Derek. 1997. The Bounty. In The Bounty: Poems. New York: Farrar, Straus and Giroux, pp. 3-18.

Walcott, Derek. 1998. The Muse of History. In What the Twilight Says: Essays. New York: Farrar, Straus and Giroux, pp. 3-35. Walcott, Derek. 2010. White Egrets: Poems. New York: Farrar, Straus and Giroux, p. 54.

White, Lynne. 1967. The Historical Roots of Our Ecologic Crisis. Science 155: 1203-7. [CrossRef] [PubMed]

Wiesel, Elie. 1984. Noah's Warning. Religion E Literature 16: 3-20.

Williams, Williams Carlos. 1956. In the American Grain. New York: New Directions Publishing.

(C) 2020 by the author. Licensee MDPI, Basel, Switzerland. This article is an open access article distributed under the terms and conditions of the Creative Commons Attribution (CC BY) license (http://creativecommons.org/licenses/by/4.0/). 
Article

\title{
Reading the Book of Nature after Nature
}

\section{Jacob Holsinger Sherman}

Department of Philosophy and Religion, California Institute of Integral Studies, San Francisco, CA 94103, USA; jsherman@ciis.edu

Received: 10 March 2020; Accepted: 16 April 2020; Published: 20 April 2020

\begin{abstract}
Early modernity tended to appeal to the trope of the book of nature as a way of securing knowledge-including knowledge about God-against the exigencies of history and culture, but as theorists such as Timothy Morton, Bruno Latour, and others have argued, today this assumed dualism of nature and culture is both ecologically and critically suspect. What might it mean to read the book of nature in a time of ecological precarity, what many have called the Anthropocene? I will argue that premodern theological traditions of the book of nature, such as one finds in the twelfth century Hugh of Saint Victor, have something extremely important to add to a postmodern 'terrestrial' hermeneutics of nature, precisely because the premodern book of nature already performs the construal of nature as culture (and of culture as nature) so often recommended today by critics such as Latour, Haraway, and others. On such an account, nature is neither a fantasy object to be ignored or fled, nor a stable text to be tamed, rationalized, and epistemically leveraged, but rather the changing concept and experience of nature is a symbol illuminated in a book we half receive, and half create, a symbol open to both critique and contemplation, which gives rise to thought, action, and the sort of novel moral intuitions we need now more than ever.
\end{abstract}

Keywords: Book of Nature; Hugh of Saint Victor; Anthropocene; Bruno Latour; Timothy Morton; Slavoj Žižek; ecology and religion; eco-theology

\section{Introduction}

As we confront the advent of the state of universalized precarity and massive global changes entailed by "the new climatic regime," as Bruno Latour calls it, the vulnerability of our practices, traditions, and the human condition itself become ever more apparent (Latour 2018). How do we respond to challenges of such scope? More to the point of this Special Issue on 'Faith, Vulnerability, and the Anthropocene,' we might ask: are there resources within the intellectual and spiritual traditions of communities of faith that can help us in the collective effort to discover the moral sources required to meet the unprecedented tests of our time?

To many, it might seem absurd to suggest that the humanities, let alone philosophy or theology, could have anything to say about such an intractably material situation as the contemporary ecological crisis; surely, only science can save us now? And yet, one can argue, that our predicament is not only a technical and scientific crisis, but also a crisis of human collective activity, which is to say, of politics, and so depends crucially upon human commitment, imagination, and deliberation (Arendt 1998). The paradox of the Anthropocene is this: human agency is now responsible for fundamentally transforming the biogeochemistry of the earth, while at the same time, we seem incapable of altering the shape of our collective activities. We are tragically responsible, and we can't seem to do anything about it.

But might this paradox seem intractable only because basic ontological, ethical and aesthetic assumptions have gone unquestioned? And, if so, doesn't this cry out for a metaphysical and theological response? 
One of the most important of these often-elided questions is the relationship between human beings and nature, a relationship that was once taken for granted, but that now appears deeply unstable in the epoch of the 'Anthropocene'. Early modern philosophy taught us to appeal to nature as a source of certainty and universality, an epistemological bulwark against the exigencies of history and culture, but today this assumed dualism of nature and culture is both ecologically and critically suspect. There is moral risk here, for 'nature' seems to have been the constitutive good in relationship to which so many of the novel moral intuitions and practices of our ecological consciousness came into being. ${ }^{1}$ Can we still appeal to nature, and what might that appeal look like in a time of ecological precarity? In order to address such concerns, this essay begins by critically considering the contemporary scholarly questioning of the very concept of nature, and then argues that the creative retrieval of premodern theological traditions of the book of nature might provide key tools for the construction of the kind of postmodern 'terrestrial' hermeneutics of nature we need now more than ever.

\section{The Problem of 'Nature'}

What's the matter with Nature? One way to think about it would be as follows. Ever since the nineteenth century, environmental and ecological ethics have tended to appeal to a unified concept of nature as a given, well-ordered, moral and biophysical whole that must be saved, managed or preserved. Formally, this peculiarly modern understanding trades on a disjunctive theory of nature as wilderness: the wilderness or the wild is all that is other from culture. Materially, such appeals are seen at work in strategies which aim to draw boundaries between nature and the human in order to create a preserve or protected space from the influence of human technology and culture-making. Today, however, this idea of nature as corrupted by the supplement of culture is increasingly contested.

To begin with, the unified modernist concept of nature has been thrown into question by research in the history, sociology, and philosophy of science (Latour 1993, 2004; Stengers 2010; Grebowicz et al. 2013; Haraway 2016a, 2016b). We can take Bruno Latour as representative here. According to Latour, the critique of nature is bound up with a critique of modernity. On Latour's account, modernity defines itself by erecting an absolute dualism between nature and society, an establishment accomplished by the elevation of the human subject out of nature and into the putatively transcendent realm of culture. We are, I assume, all familiar with accounts of modernity that make this sort of Cartesian or Kantian dualism central to the identity of the modern. What Latour adds to this common story, however, is a strong account of how this modern aspiration to purify the realms of nature and culture both came about, and how it has always been undone by the equally modern aspiration to 'illicitly' mix these two realms. Thus, modernity is marked not by one but by two fundamentally conflicting practices that Latour calls 'purification' and 'translation' (Latour 1993, pp. 8-12). In purification, moderns seek through experimental and analytic means to construct a nature freed from culture and subjectivity, while in translation (or 'hybridization') moderns bring together these supposedly pure spheres in new hybrid assemblages of nature and culture (Latour 1993, pp. 39-48).

Hybrids, however, remain invisible to modern eyes. Modernity understands itself only in terms of the first procedure of purification. This is the story we were all taught. Modernity purifies the world; it separates the value spheres of the good, the true, and the beautiful, and so frees the world from antique superstition. The earth no longer groans, trees no longer speak, and the heavens dictate neither our moods nor the proper construction of the republic. Nature exists in its pure brute calculability, mute,

1 The vocabulary here is Charles Taylor's. Taylor distinguishes between 'constitutive goods' and 'life goods'. A "constitutive good is a moral source ... that is, it is a something the love of which empowers us to do and be good" (Taylor 1989, p. 93). Life goods, by contrast, are things it is good to be, what are often called virtues. But these life goods are goods precisely because of their relationship to some substantive aspect of reality, the constitutive good, relation to which constitutes the goodness of life goods and empowers the agent in his or her moral actions. Although a genealogical account of how we came to see environmental questions as ethical and not merely pragmatic is beyond my scope here, one can argue that 'Nature' often played a key role as the constitutive good in the emergence of ecological virtues throughout the nineteenth and twentieth centuries. 
stupid, and subject to the laws of mechanical necessity. With nature scoured of any human or personal trace, a new Promethean humanity discovers (or invents) itself as utterly free from the constraints of nature. What it means to be modern is to distill finally culture from nature, the discursive from the real, the social, linguistic, and constructed from the natural, material, and given. As one of Latour's interpreters explains, "Modernity tries to purify the world by dissecting it into two utterly opposed realms. On one side we have the human sphere, composed of transparent freedom and ruled by arbitrary and incommensurable perspectives. On the other side we have nature or the external world, made up of hard matters of fact and acting with objective, mechanical precision" (Harman 2009, p. 57).

The error of premodern peoples, so the story goes, was to believe in a seamless fabric of nature and culture: political arrangements were believed not only to model but also to follow the heavens, signatures were spread throughout the world of nature, the moon somehow connected to the growing of seeds or to the metal silver, the sun for its part sympathetic to gold, our own bodies and moods composed of the four elements that make up our temperaments ... a world of cosmos, psyche and politeia all mixed, confused. But moderns, it is said, put to an end this confusion. "[They] have cut the Gordian knot with a well-honed sword. The shaft is broken: on the left, they have put knowledge of things; on the right, power and human politics" (Latour 1993, p. 3).

As Latour develops his account, he shows that the modern process of purification is a bit more complex still. Modernity separates-horizontally as it were-nature from culture, but it also vertically separates nature and culture from God, divinity, and the spiritual realm, a God that is now crossed-out because incapable of ever appearing within a world entirely divided between nature and culture. Latour writes, "Modernity arises first from the conjoined creation of these three entities [exclusive humanity, nonhuman nature, and the crossed-out God], and then from the masking of the conjoined birth and the separate treatment of the three communities while, underneath, hybrid continue to multiply as an effect of this separate treatment" (Latour 1993, p. 13). For the modernizers, if God is allowed to be anywhere, it's in the interiority of mind and soul, but never in the land, the laws, or the economy. Modernity is premised upon a double-process of separation: humans from nonhumans and above from below.

Of course, Latour insists that we have never in fact been modern, in the sense that we have never succeeded — could never succeed - in finally purifying nature and culture, but this leads to the worry that perhaps neither have we ever known nature. The very concept of nature may be a will-of-the-wisp.

This account becomes even more powerful when read alongside the great transformations to Earth systems that provide the theme for this Special Issue. The growing awareness that human influence is now so ubiquitous upon the surface of the earth that strictly speaking 'untrammelled nature' no longer exists has led an increasing number of scientists, scholars, and activists to speak of the Anthropocene. ${ }^{2}$ As the ultimate instance of hybridization, climate change exposes the unsustainability of the modern bifurcation of nature and culture and casts both poles of this bifurcated reality under a cloud of critical suspicion.

According to the philosopher Slavoj Žižek, the situation is even more extreme than this. It is not only that humanity has become a ubiquitous presence and geological force, altering earth systems that will be catastrophic for many, but also that we have reached into the previously hidden depths of nature and, as it were, taken control. As Žižek writes: "the main consequence of the scientific breakthroughs in biogenetics is the end of nature. Once we know the rules of its construction, natural

2 Defining even what the Anthropocene means is controversial. Whatever else it means, it refers to the enormous influence of human beings upon the entire terrestrial system (Lewis and Maslin 2018). As is now well known, human activity has increasingly displaced the more-than-human world to the point that we have left such a mark and our presence has grown so ubiquitous that we are now rightly described as a geological agent. Use of the term in this context is credited to the Dutch atmospheric chemist, Paul Crutzen, who claimed that the human, the Anthropos, had become such a "geoforce" that we were no longer living in the Holocene but rather in the Anthropocene (Crutzen 2006). As the popularity of the term has grown, so too has scholarly recognition of the theoretical, philosophical and theological challenges it poses (Hamilton et al. 2015; Deane-Drummond et al. 2017). 
organisms are transformed into objects amenable to manipulation ... . nature is no longer "natural," the reliable "dense" background of our lives; it now appears as a fragile mechanism which, at any point, can explode in a catastrophic manner" (Žižek 2008a, p. 435). For Žižek, the paradigm case of this is biogenetics, which reduces the human psyche itself to an object of manipulation. "By reducing [the human] to just another natural object whose properties can be manipulated," writes Žižek, "what we lose is not (only) humanity but nature itself" (Žižek 2008a, p. 435).

Žižek is not the first to note this. Already in the middle of the last century, C. S. Lewis had argued something similar. In The Abolition of Man, Lewis argued that "we reduce things to mere Nature in order that we may 'conquer' them. We are always conquering Nature, because 'Nature' is the name for what we have, to some extent, conquered. The price of conquest is to treat a thing as mere Nature. Every conquest over Nature increases her domain. The stars do not become Nature till we can weigh and measure them: the soul does not become Nature till we can psychoanalyse her" (Lewis 2001, p. 43).

With the horrors of National Socialism in mind, Lewis imagined that the end point of this process would finally be the conquering of the human itself, the abolition of man, for once we reduce our species to mere nature, we lose both nature and humanity. By reducing nature to a story of particles and their relations, or to atomic forces and nomological regularities, and so by removing from the world its dynamic, vital, ensouled meaning, we 'discover' ourselves in a vast material machine subject either to mechanical or stochastic laws rather than in a cosmos replete with inescapable meaning. But having discovered that we dwell in such a universe, we eventually discover that the body too is subject to these very modes of mechanical understanding, at which point the life of the body becomes essentially unintelligible, and we begin to suspect that we ourselves are nothing but anticipatory corpses (Bishop 2011). Finally, we turn the analysis back on the very consciousness doing the analyzing and we dissolve ourselves into the pulverized bits of universe to which we've reduced everything else.

But where Lewis laments this final magician's bargain-give up our soul, get power in return-Žižek welcomes it in the name of an ecology without nature: "The ultimate obstacle to protecting nature is the very notion of nature we rely on" (Žižek 2008a, p. 435). The posthuman future that modern science and technology have inaugurated is thus rather ironically dubbed the Anthropocene, but for Žižek it conclusively demonstrates the falseness of the old picture of nature, the picture that held us captive when we still also believed in humanity.

Žižek's conclusions have been significantly bolstered by certain strands of literary ecocriticism, which have increasingly demonstrated that concepts of nature in foundational ecological texts are geographically particular, socially contingent, imaginative and even theological. ${ }^{3}$ In place of the unified book of nature invoked both by classical environmentalists and early modern scientists, the ecocritics point instead to an array of constructed natures, each imaginatively apprehending and evaluating reality in different ways.

Timothy Morton, for instance, argues that our ongoing appeal to the idea of nature is vitiating our ecological politics. As he writes: "The idea of 'nature' ... will have to wither away in an 'ecological' state of human society. Strange as it may sound, the idea of nature is getting in the way of properly ecological forms of culture, philosophy, politics, and art." (Morton 2007, p. 1).

Morton argues that, hitherto, ecocriticism has engaged in too much advocacy and too little criticism. Instead of cheering for nature, it ought to be destabilizing the very concept-even refusing to reinvent the concept:

When I suggest that we drop the concept of nature, I am saying that we really drop it, rather than try to come up with hastily conceived, 'new and improved' solutions.... 'Ecology

3 On the contested meanings of the word 'nature' see (Gersdorf and Mayer 2006; Clark 2011; Lewis 1960; Collingwood 1945; Williams 2014; Hadot 2006; Williams 1980; Latour 1993; Evernden 1992; Rolston 1997; Whitehead 2015; Morton 2013b). For a sampling of religious and theological responses to this conceptual diversity, see (Kaufman 1972; Albertson and King 2010; McGrath 2001). 
without nature' is a relentless questioning of essence, rather than some special new thing ... . (Morton 2007, p. 21)

If we relentlessly question nature, we find that it disappears; and in its place-as Collingwood observed-all that is left is history and change (Collingwood 1945). The concept of nature elides this impermanence from our view and provides the illusion of a stable ahistorical ground upon which human culture and history take their privileged place.

The concept of nature that Morton and Žižek primarily target stems from literary innovations canonized in the Romantic Movement of the 18th and early 19th centuries, which, Morton argues, still shape our ecological imaginary: they taught us to believe that a view of things-especially a view of nature-could change the world: "Nature," Morton writes, "is the reduction of nonhuman beings to their aesthetic appearance for humans" (Morton 2013b, p. 311). It's a spectatorial project. Romanticism, the aesthetic parent of nature writing and nature poetry, is the parent of contemporary ecological consciousness, to be sure, but on Morton's account it is an abusive parent, for while the Romantic view of nature sets our hearts aflutter, its aestheticism stops us thinking and spoils our politics. By taking leave of it, they take leave as well of the naive summer-of-love ecospirituality that influenced so much of the previous decades' popular environmentalism in general, and discussions of religion and ecology in particular.

At this point, many of us who have learned from the Romantics and the nature writing tradition will want to register our doubt. ${ }^{4}$ Contemporary critiques of Romanticism tend to accuse it of opposite vices: both of rendering nature too other as 'the wild' and yet of covertly taming nature by subjecting it to an even more powerful aesthetic anthropocentrism. This aporetic doubling of Romanticism's infractions may in fact apply to some in the canon, but not to thinkers like Wordsworth, Coleridge, or, for that matter, Annie Dillard. These poetic thinkers justified and acknowledged a certain anthropocentrism not through a transcendental elevation of the subject alone, but rather by including the human alongside all regarded creatures as bound within a single divine creation.

Latour also thinks that our concept of nature is spoiling our politics, but for him the primary culprit is less the nature of early modern romanticism than the nature of early modern science. Ever since Galileo, we have increasingly acted as if the only true account of nature were one that could be rendered in the mathematics applicable to the physics of falling bodies, that is to say, a view of the Earth from outside, outside our ecological niches, outside our bodies, outside of subjectivity itself. After all, it was Galileo who insisted in The Assayer:

Philosophy is written in this grand book-I mean the universe-which stands continually open to our gaze, but it cannot be understood unless one first learns to comprehend the language and interpret the characters in which it is written. It is written in the language of mathematics, and its characters are triangles, circles, and other geometrical figures, without which it is humanly impossible to comprehend a single word of it ... without these, one wanders about in a dark labyrinth.... nature takes no delight in poetry. (Galilei and Drake 1990)

Nature comes to mean just what can be measured with our rulers and clocks, what can be calculated, and nothing more. Latour calls this a 'sadistic asceticism' through which we trained ourselves to

4 Morton allows that the nineteenth century poets were richer and more nuanced than the popular nature movements they helped to fuel. Here, we might distinguish the term Romantic, as a kind of cultural sensibility, from the Romantics, that is, the authors, poets, and artists themselves. The reception history of the Romantics may give rise to the naïve 'Romantic' traditions of nature about which Morton is so critical. Nevertheless, in his more recent works, Morton allows that the Romantics themselves were more lucid than this: "It's just not correct to think of them as naive nature writers, as we too often do, even though they did tell stories about encountering mountains or hearing the terrifying yet invigorating sound of the surf. In fact, they were trying to get past all that pretty nature stuff, which was old by the time they started ... . [The British Romantics'] approach suggests a less anthropocentric attitude, and one that was in fact more in line with scientific curiosity; they were laying bare how their stance changed what they were seeing" (Morton 2018, pp. 143-44). 
acknowledge as real only that which obeys the grammar of number and mechanism. "Hence," he writes, "the classic division between knowledge seen from afar but assured, and imagination, which saw things up close but without grounding in reality: at worst, simple fairy tales, at best, ancient myths, respectable but without verifiable content" (Latour 2018, p. 69).

Why has the modern ecology movement been so singularly unsuccessful in mobilizing the political and social action needed to meet the challenge of massive disruptions of earth systems? Because a reified concept of nature as the other of culture also rends asunder metaphysics and morality, positive knowledge and religious feeling, thus leaving us bereft of moral categories adequate to the integral complex of nature and culture that constitutes climate change.

From Morton to Žižek to Latour, all agree that the concept of nature has become unsustainable. But what do they offer in its place? On the one hand, in the name of getting rid of nature, Žižek and Morton return us to something like naturalism in its starkest form; the world may be stranger, more magical or more monstrous than run-of-the-mill naturalism allows, but, nevertheless, for both authors the radical alterity of nature becomes a deromanticized wilderness, the desert of the real (Žižek 2008b). Nothing ever actually touches anything else: indeed, in at least one of his moods, Morton commends a kind of chastened Cartesianism claiming that what we ought to adopt is a substance-less Cartesian dualism (Morton 2013b). Subjects are subjects irreducibly related to the horrifyingly brute vacuous actuality of others, the strange strangers that surround them. If communication is possible across so great a divide, it can only be a kind of unmediated, inexplicable communication-a nihilistic occasionalism, a realist magic (Morton 2013a). But such an ontological wilderness, because it offers no genuine communion, and is in its depths unreachable, is ironically just the kind of wilderness that makes itself available for human exploitation. Without the poetry, and in lieu of any human access to the alien reality of natural things, it would seem that all we can act upon are the deliverances of scientific reason and the demands of rational politics. There is no extra-linguistic whole which might bestow a value beyond the political or economic upon creatures.

For his part, Latour insists by contrast that relationship takes absolute priority over both the parts and the whole, but this has problems of its own. On the one hand, if parts are never themselves save through their exhaustive constitution by dynamic relations, then every individual-every actor, every agent-is infinitesimally composed of relations to other agents who only are through their infinite relations, each simultaneously formed and transformed, like Actaeon, only to be torn apart by its changing relations to every other. On the other hand, even relations themselves seem to dissolve if there is no whole transcending these relations, for movement and change are only possible if some substantial identity transcends such change-in the absence of this wholeness, there is only replacement, which, when universalized, is indistinguishable from stasis.

\section{Retrieving the Book of Nature}

"Nature," writes Holmes Rolston, "is perhaps the most ancient philosophical category, yet few others are of greater current relevance" (Rolston 1986, p. 9). Nevertheless, those seeking an ecology without nature insist that the concept of nature, in its vague, constantly renegotiated identity, is just a series of contingent metaphors and that the business of careful political ecology can dispense with these. I am inclined to agree that nature is a metaphor, one that is shot through with contingency and historicity. But I want to be cautious about dispensing with it. For one thing, as Pierre Hadot writes, "a metaphor is never innocent. It is the vehicle of an entire set of images, feelings, and inner dispositions, which have an unconscious influence on consciousness" (Hadot 2006, p. 76). If the morally novel developments of, say, the environmental movement have been mediated to us through the metaphor or symbol of nature, we should be cautious about dispensing with that symbol too quickly. In his Poetics, Aristotle notes that there can be no ethos without a mythos. ${ }^{5}$ If we relinquish the

5 Poetics 1450a.15-1450b.4. 
symbol of nature, even in the name of radical ecology, we may find our meta-ethical grounds disappear along with it.

But if we are attentive to the contingencies of history and culture, to the functioning of ideology, and projection, how can we continue to make ethical appeals to nature without bad faith?

Here, I think, the theological tradition of the book of nature has something extremely important to add. As I have intimated already, early modernity tended to appeal to the trope of the book of nature as a way of securing knowledge-including knowledge about God-against the exigencies of history and culture. For modern natural philosophers, the book of nature provided a hidden but trustworthy script—one that could be read identically so long as certain procedures were followed —and that thus provided the necessary foundations for modern science. For early modern theologians, the book of nature played an equally foundational role. Following the late-medieval Raymond of Sabunde's The Book of Nature or Creatures [Liber naturae sive creaturarum], so-called natural theology was called upon to stand in the skeptical breach providing certainty, apodicticity, and a set of evidences for religion unrelated to the presuppositions of faith (Harrison 2015, p. 73; Wolterstorff 2010).

This was a reading of precisely the sort of nature against which Latour and others have rightly raised a critique, but until its early modern transposition into the language of mathematics, the theological trope of the book of nature operated quite differently. Indeed, for more than a millennia, the liber naturae tradition constituted a vision of nature not as a bulwark against contingency but as ineluctably hermeneutical, susceptible to being known in positive ways, to be sure, but irreducible to any particular exegesis of its being.

This premodern tradition of the book of nature envisions a co-constitutive relationship between humanity and nature that already performs the construal of nature as culture (and of culture as nature) so often recommended today. In this regard, premodern theological traditions of the book of nature may provide resources for the construction of a postmodern 'terrestrial' hermeneutics of nature, a reading of nature that recognizes its agency alongside and within our own. ${ }^{6}$ For if Creation is the divine work, the product of the divine 'culture', then it cannot be poor in meaning compared with our human products; indeed, it must be saturated with a deeper, partly hidden meaning.

With origins in antiquity, especially with Augustine, the metaphor of the book of nature came to prominence in that alter-Augustinus, Hugh of St Victor, during the so-called twelfth-century rediscovery of nature (Angelici 2020; Cizewski 1987; Coolman 2010; Falque 2017; Chenu [1957] 1997; Illich 1993). For Hugh, the motif points to an equally spiritual and hermeneutical approach to the 'reading' of creation, taken to be inseparable from the community's concomitant reading of scripture (Falque 2017). If creation is itself a book, analogous to the book of scripture, then our relationship with creation is one that resists in advance both modern pretensions to the mastery, and possession of nature, and the prevalence of any ultimate nature/culture duality. Instead, our reading of nature, as our reading of scripture, can only be undertaken through a kind of contemplative theological comportment, a specific way of life informed by communal practices whose ultimate shape is Christological and whose ultimate aim is doxological.

As Hugh writes in his meditation, De Tribus Diebus 4.3, "For this whole sensible world is a kind of book written by the finger of God, that is, created by divine power, and each creature is a kind of figure, not invented by human determination, but established by the divine will to manifest and in some way signify the invisible wisdom of God" (Coolman and Coulter 2010, p. 63).

Despite the reference to Romans 1:20, Hugh doesn't deploy natural theology in the way that modern readers of the book of nature would, in the service of the proofs for the existence of God. Rather, he insists that the book of nature be wedded to a kind of paideia, a cultivation of the 'art of reading' [ordo legendi] which corresponds equally to an 'art of living' [ordo vivendi]:

6 On the notion of the 'terrestrial, see (Latour 2018, pp. 40-42). 
Just as when an unlettered person sees an open book and notices the shapes but does not recognize the letters, so ... people who are not aware of the things of God see on the outside the beauty in these visible creatures, but they do not understand its meaning. (Coolman and Coulter 2010, p. 63)

How are we to be made capable of understanding this meaning? We must allow ourselves to be opened, to be shaped, and formed to become other. Characteristically for Hugh, as earlier for Augustine, to be formed means to be taught how to read, to attend to the other, and for this purpose God sent yet another book. As Hugh explains in De Sacramentis (1.6.5), "Wisdom was a book written within; the work of wisdom [that is, creation] a book written without." But human sin has darkened our eyes to these books, so God sent another volume, one that not only signifies but illumines: the book of the Incarnation of the Son of God.

He assumed flesh not losing divinity, and was placed as a book written within and without; in humanity without, within in divinity, so that it might be read without through imitation, within through contemplation ... . (Hugh of Saint-Victor 2007).

The intertextual Christological tearing of the veil between nature and culture couldn't be more pronounced. Books are, of course, synecdoches for culture, but as Hugh's remarkable treatise on reading, the Didascalicon, makes clear, in this twelfth-century context books abound in the most surprising of places: Scripture, to be sure, but also nature, the world, the arts of hunting, cooking, farming, our bodies themselves, and the incarnate body of Christ-all are available to be read (Hugh of Saint-Victor 1991). Moreover, they are read in unexpected ways that include the whole pattern of our ethical lives (reading as imitation) and the most elevated ascent of our minds (reading as contemplation). The historical event of the incarnation and the ways of life-the ecclesia-to which it gives rise train and empower the believer not only to interpret scripture, but also nature, and indeed his or her own life, for, in this way, one's life itself also becomes a book written by the finger of God.

\section{Conclusions}

The ontological implications of this are profound. As Latour has argued, once we dispense with a demarcation of nature and culture, human freedom, culture, and imagination must themselves be seen to participate in nature-rather than modernist self-transparency, we discover a kind of wildness within our very selves and cultures, which displays the same opacity as nature without. Nature is the otherness that surrounds us, and the otherness that indwells us (Latour 1993).

If the universe is not bifurcated into active agents of meaning, on the one hand, and stubborn facts, on the other, then at least two strategies of approaching the universe open to view. Either, we might see meaning itself as fundamentally illusory, the sort of thing that dissolves once we rid ourselves of the illusions of our own superiority. Or, we might alternatively see wisdom and intelligibility as ontologically basic, and so expect to find the world itself replete with a plenitude of meaning and agency. In this respect, the best of Romantic 'anthropomorphising' is saved. It is not a lapse into the pathetic fallacy that lilies have feelings like ours, but a repetition of nature's hidden significance which involves simultaneously the 'naturalising' of our own human responses. The lily imbued with our response is also our response imbued with the entrancing strangeness of the lily.

On such an account, we might expect to find within our own active capacities a kind of participation in, or expression of the ubiquitous meaning-making of the universe. This is not an expression of anthropocentric artistic arrogance: instead, in order to mean in some respects beyond the lily, we must first attend to its own utterances. Only with such vulnerable communion does a reading of the book of nature become also legitimately our own continued writing of it. This is what we find in Hugh's account, and so much of the theological tradition alongside him: nature not as a concept but as a symbol, not only the symbol of divinity, but finally the symbol of the union of God and creation in the man Jesus Christ, the Logos-Wisdom through whom all things were made and who on earth 
could speak the word that turned water into wine, restored damaged natures, and caused the dead to live again.

Nature as creation, participating in and suspended from the Triune God, functions as the value-bestowing constitutive good that we found wanting in contemporary accounts of ecology without nature. But it has this capacity not as a substance among other substances, nor a thing existing alongside of and in contrast to other things of the world, but precisely as a symbol. A symbol is, of course, a sign, but a sign that partakes synechdochically of that which it signifies. This is what distinguishes it from a mere representation which presents a kind of external similitude, and so invites definition or decoding, while a symbol enjoys an internal and unfinished relationship with its referent, a real ontological correspondence that makes it to be what it is, and at the same time, to be a symbol (Borella 1989). As Paul Ricoeur writes:

The manifestation through the [symbol] thing is like the condensation of an infinite discourse; manifestation and meaning are strictly contemporaneous and reciprocal; the concretion in the thing is the counterpart of the surcharge of inexhaustible meaning which has ramifications in the cosmic, in the ethical, and in the political. Thus the symbol-thing is the potentiality of innumerable spoken symbols which, on the other hand, are knotted together in a single cosmic manifestation. ${ }^{7}$ (Ricœur 1967, p. 11)

Accordingly, symbols invite contemplation more than definition. Modern theories of the symbol have tended to aestheticize them, holding that symbols signify, to be sure, but also that they signify nothing beyond immanent human experience. This is often taken to be a consequence of their social construction: if we immanent beings make symbols, then surely the symbols can, at best, signify us. At this point a theory of projection is still sadly in league with the pathetic fallacy. We encountered a similar logic above in Žižek and Morton, albeit with Lacanian and Derridean or object-oriented spins respectively, but for Hugh, the symbol of nature was discovered more than invented, received more than made. Thus, the contemplation the symbol evoked was not limited to a human horizon. Morton, in getting rid of nature, would seem to get rid of all normativity in the name of human species-modesty. But following Hugh of Saint Victor's example, in the name of nature as Creation, we are able to sustain human dignity in a measured way, while encouraging a real vulnerability towards a nature that is all the more normative insofar as we are forever having to relearn its subtle and complex standards-a nature saturated with meaning beyond our human limits. ${ }^{8}$

Is this merely a regression to the erroneous premodern belief in a seamless fabric of nature and culture? Surely not, and this for two reasons. First, as Latour argues, the putative error only appears as such in light of the modern project decisively to separate nature and culture, a project that has always betrayed itself by covertly appealing to hybrids of all sorts, as is especially evident today with the advent of the Anthropocene. Moreover, one might argue, in the second place, that the premodern error lies not as modernity pretended in the conflation of nature and culture, but rather in the insistence that nature (and thus the ideals of culture) be timeless and necessary, somehow given apart from the

7 Appropriately, the context for Ricoeur's comment is his discussion of the symbols of nature. The entire passage reads: "First of all, then, it is the sun, the moon, the waters-that is to say, cosmic realities-that are symbols. Shall we say, therefore, that symbols, in their cosmic aspect, are interior to language, or even foreign to it? Not at all. For these realities to be a symbol is to gather together at one point a mass of significations which, before giving rise to thought, give rise to speech. The symbolic manifestation as a thing is a matrix of symbolic meanings as words. We have never ceased to find meanings in the sky. . . It is the same thing to say that the sky manifests the sacred and to say that it signifies the most high, the elevated and the immense, the powerful and the orderly, the clairvoyant and the wise, the sovereign, the immutable. The manifestation through the [symbol] thing is like the condensation of an infinite discourse; manifestation and meaning are strictly contemporaneous and reciprocal; the concretion in the thing is the counterpart of the surcharge of inexhaustible meaning which has ramifications in the cosmic, in the ethical, and in the political. Thus the symbol-thing is the potentiality of innumerable spoken symbols which, on the other hand, are knotted together in a single cosmic manifestation" (Ricœur 1967, p. 11).

8 In fact, a genealogy can be traced from the medieval contemplative liber naturae through to Romantic retrievals of the trope of the book of nature against its modern reduction to mathematics. The whole story has yet to be told, but key elements of it can be found in Brett Grainger's recent work (Grainger 2019, pp. 61-104). 
contingencies of history and becoming. This is what produces ideological appeals to nature, in that nature becomes a shortcut around politics, history, negotiation, and interpretation. But nature is not simply given, necessary, and therefore something to be passively received. Nature is not the stable backdrop for human activity and drama, but a dynamic participant in the drama of creation, of which we are all a part. This, perhaps, is something the twelfth-century Victorines could not yet know, but it is also something about which early modern philosophers were equally ignorant. The nineteenth century discovery of nature's vast history, and the new sense of our evolutionary and cultural historicity, undoubtedly transforms our reading of the book of nature. The book of nature is written in a living script. Arguably, however, the discovery of deep time more easily comports with Hugh of Saint Victor's refusal of any ultimate distinction between nature and culture than it does with modernity's characteristic bifurcation of the two. Beyond, but not against, what the premodern Hugh of Saint Victor knew, we might argue in postmodern fashion that if our creative symbol-making capacities are not merely expressions of transcendental human freedom, but rather if our creative and historical capacities are received like gifts, because we too are part of nature, we can in principle reconcile the opposition of active creation and passive reception without returning either to the modern illusion of a merely 'given' factual nature or to the demoralizing skepticism of thoroughgoing nominalism which assumes a purely 'willed' culture somehow outside and beyond nature.

Much more needs to be said in order to do justice to this argument, but we have at least established the possibility of a theological invocation of nature that escapes the now-problematic bifurcations of modernity, on the one hand, and the essentializing reifications of premodernity, on the other. By contrast, in accord with a more terrestrial hermeneutics of the book of nature, nature is neither a fantasy object to be ignored or fled, nor a stable text to be tamed, rationalized, and epistemically leveraged. Read theologically and Christologically, a creative retrieval of the book of nature is neither an exercise in nostalgia nor anachronism, for nature is not merely given, either for exploitation or sentiment. Rather, nature and the moral stances that nature empowers are able to remain without falling prey to the unravelling of recent critical theory. But nature remains precisely by relinquishing the pretensions to certainty and the immunity to history that so attracted her modern devotees. Instead, the changing concept and experience of nature is a symbol illuminated in a book we half receive and half create, a symbol open to both critique and contemplation, which gives rise to thought, action, and the sort of novel moral intuitions we need now more than ever.

Funding: This research received no external funding.

Conflicts of Interest: The author declares no conflict of interest.

\section{References}

Albertson, David, and Cabell King. 2010. Without Nature?: A New Condition for Theology, 1st ed. New York: Fordham University Press.

Angelici, Ruben. 2020. Semiotic Theory and Sacramentality in Hugh of Saint Victor, Contemporary Theological Explorations in Mysticism. Oxford and New York: Routledge.

Arendt, Hannah. 1998. The Human Condition, 2nd ed. Chicago: University of Chicago Press.

Bishop, Jeffrey Paul. 2011. The Anticipatory Corpse: Medicine, Power, and the Care of the Dying, Notre Dame Studies in Medical Ethics. Notre Dame: University of Notre Dame Press.

Borella, Jean. 1989. Le Mystère du Signe: Histoire et Théorie du Symbole, Collection Métalangage. Paris: Maisonneuve \& Larose.

Chenu, Marie Dominique. 1997. Nature, Man, and Society in the Twelfth Century: Essays on New Theological Perspectives in the Latin West. Translated by Jeremy Taylor, and Lester K. Little. Toronto: University of Toronto Press. First published 1957.

Cizewski, Wanda. 1987. Reading the World as Scripture: Hugh of St Victor's De Tribus Diebus. Florilegium 9: 65-88.

Clark, Timothy. 2011. The Cambridge Introduction to Literature and the Environment, Cambridge Introductions to Literature. Cambridge and New York: Cambridge University Press. 
Collingwood, Robin George. 1945. The Idea of Nature. London: Oxford University Press.

Coolman, Boyd Taylor. 2010. The Theology of Hugh of St. Victor: An Interpretation. New York: Cambridge University Press.

Coolman, Boyd Taylor, and Dale M. Coulter, eds. 2010. Trinity and Creation: A Selection of Works of Hugh, Richard and Adam of St Victor, Victorine Texts in Translation. Turnhout: Brepols.

Crutzen, Paul J. 2006. The "Anthropocene". In Earth System Science in the Anthropocene. Edited by Eckart Ehlers and Thomas Krafft. Berlin/Heidelberg: Springer, pp. 13-18.

Deane-Drummond, Celia, Sigurd Bergmann, and Markus Vogt, eds. 2017. Religion in the Anthropocene. Eugene: Cascade Books.

Evernden, Lorne Leslie Neil. 1992. The Social Creation of Nature. Baltimore: Johns Hopkins University Press.

Falque, Emmanuel. 2017. The Hidden Source of Hermeneutics: The Art of Reading in Hugh of St. Victor. Journal of French and Francophone Philosophy 25: 121-31. [CrossRef]

Galilei, Galileo, and Stillman Drake. 1990. Discoveries and Opinions of Galileo: Including The Starry Messenger (1610), Letter to the Grand Duchess Christina (1615), and Excerpts from Letters on Sunspots (1613), The Assayer (1623). New York: Anchor Books.

Gersdorf, Catrin, and Sylvia Mayer. 2006. Nature in Literary and Cultural Studies: Transatlantic Conversations on Ecocriticism, Nature, Culture and Literature. Amsterdam and New York: Rodopi.

Grainger, Brett. 2019. Church in the Wild: Evangelicals in Antebellum America. Cambridge: Harvard University Press.

Grebowicz, Margret, Helen Merrick, and Donna Jeanne Haraway. 2013. Beyond the Cyborg: Adventures with Donna Haraway. New York: Columbia University Press.

Hadot, Pierre. 2006. The Veil of Isis: An Essay on the History of the Idea of Nature. Translated by Michael Chase. Cambridge: Harvard University Press.

Hamilton, Clive, Christophe Bonneuil, and François Gemenne. 2015. The Anthropocene and the Global Environmental Crisis. London and New York: Routledge.

Haraway, Donna Jeanne. 2016a. Manifestly Haraway, Posthumanities. Minneapolis: University of Minnesota Press.

Haraway, Donna Jeanne. 2016b. Staying with the Trouble: Making Kin in the Chthulucene, Experimental Futures: Technological Lives, Scientific Arts, Anthropological Voices. Durham: Duke University Press.

Harman, Graham. 2009. Prince of Networks: Bruno Latour and Metaphysics, Anamnesis. Melbourne: Re.press.

Harrison, Peter. 2015. The Territories of Science and Religion. Chicago: The University of Chicago Press.

Hugh of Saint-Victor. 1991. Didascalicon: A Medieval Guide to the Arts. New York: Columbia University Press.

Hugh of Saint-Victor. 2007. On the Sacraments of the Christian Faith: (De Sacramentis). Eugene: Wipf \& Stock Publishers.

Illich, Ivan. 1993. In the Vineyard of the Text: A Commentary to Hugh's Didascalicon. Chicago: University of Chicago Press.

Kaufman, Gordon D. 1972. A Problem for Theology: The Concept of Nature. Harvard Theological Review 65: 337-66. [CrossRef]

Latour, Bruno. 1993. We Have Never Been Modern. Cambridge: Harvard University Press.

Latour, Bruno. 2004. Politics of Nature: How to Bring the Sciences into Democracy. Cambridge: Harvard University Press.

Latour, Bruno. 2018. Down to Earth: Politics in the New Climatic Regime. English ed. Cambridge and Medford: Polity.

Lewis, Clive Staples. 1960. Nature (with Phusis, Kind, Physical, etc.). In Studies in Words. Cambridge: University Press, pp. 24-74.

Lewis, Clive Staples. 2001. The Abolition of Man, or, Reflections on Education with Special Reference to the Teaching of English in the Upper Forms of Schools. San Francisco: HarperSanFrancisco.

Lewis, Simon L., and Mark Maslin. 2018. The Human Planet: How we Created the Anthropocene. New Haven and London: Yale University Press.

McGrath, Alister E. 2001. A Scientific Theology: Nature. Grand Rapids: Eerdmans Pub. Co., vol. 1.

Morton, Timothy. 2007. Ecology without Nature: Rethinking Environmental Aesthetics. Cambridge: Harvard University Press.

Morton, Timothy. 2013a. Realist magic: Objects, ontology, causality. In New Metaphysics. Ann Arbor: Open Humanities Press.

Morton, TImothy. 2013b. X-ray. In Prismatic Ecology: Ecotheory beyond Green. Edited by Jeffrey Jerome Cohen. Minneapolis: University of Minnesota Press, pp. 311-27.

Morton, Timothy. 2018. Being Ecological. Cambridge: The MIT Press.

Ricœur, Paul. 1967. The Symbolism of Evil. In Religious Perspectives, 1st ed. New York: Harper \& Row. 
Rolston, Holmes. 1986. Philosophy Gone Wild: Essays in Environmental Ethics. Buffalo: Prometheus Books.

Rolston, Holmes. 1997. Nature for Real: Is Nature a Social Construct. In The Philosophy of the Environment. Edited by Timothy D. J. Chappell. Edinburgh: University of Edinburgh Press, pp. 38-64.

Stengers, Isabelle. 2010. Cosmopolitics. In Posthumanities. 2 vols. Minneapolis: University of Minnesota Press.

Taylor, Charles. 1989. Sources of the Self: The Making of the Modern Identity. Cambridge: Harvard University Press.

Whitehead, Alfred North. 2015. The Concept of Nature: The Tarner Lectures Delivered in Trinity College, November 1919. Cambridge Philosophy Classics ed. Cambridge: Cambridge University Press.

Williams, Raymond. 1980. Ideas of nature. In Problems in Materialism and Culture: Selected Essays. London: Verso, pp. 67-85.

Williams, Raymond. 2014. Nature. In Keywords: A Vocabulary of Culture and Society. Oxford and New York: Oxford University Press, pp. 164-70.

Wolterstorff, Nicholas. 2010. The MIgration of Theistic Arguments from natural theology to evidentialist apologetics. In Practices of Belief: Selected Essays. Cambridge and New York: Cambridge University Press, pp. 173-216.

Žižek, Slavoj. 2008a. In Defense of Lost Causes. London: Verso.

Žižek, Slavoj. 2008b. Nature and Its Discontents. SubStance 37: 37-72. [CrossRef]

(C) 2020 by the author. Licensee MDPI, Basel, Switzerland. This article is an open access article distributed under the terms and conditions of the Creative Commons Attribution (CC BY) license (http://creativecommons.org/licenses/by/4.0/). 
Article

\title{
Reimagining Christian Hope(lessness) in the Anthropocene
}

\author{
Timothy Robinson \\ Brite Divinity School at Texas Christian University, Fort Worth, TX 76129, USA; tim.robinson@tcu.edu \\ Received: 10 March 2020; Accepted: 10 April 2020; Published: 15 April 2020
}

\begin{abstract}
Faith in the Anthropocene requires a re-imagined account of Christian hope. Research on the emergence of eco-anxiety disorder shows that climate crisis and ecological destruction have psychological and emotional effects on persons and communities, producing fear, despair, and hopelessness. Accounts of hope in recent environmental literature and in traditional Christian formulations rely on faith in political will, technological innovation, or an omnipotent divine sovereign to intervene and save. Such accounts are inadequate for this moment. A re-imagined notion of Christian hope will embrace hopelessness, understood as the relinquishment of false optimism that the climate crisis can be reversed and a commitment to act without expectation of success, but with a commitment to nurturing the wisdom to live more humanly.
\end{abstract}

Keywords: eco-anxiety; despair; hope; virtue; climate crisis; Anthropocene

\section{Introduction}

Eco-anxiety is increasingly in the news these days and it is manifesting as a crisis of hope. Understood as psychological or emotional stress, distress, or grief triggered by increasing awareness of deteriorating environmental conditions and the planetary scope of the ecological crises we now face, the term "eco-anxiety" first appeared in print in a 1990 Washington Post article about the efforts of activists in Maryland to protect the local waterways that feed the Chesapeake Bay. ${ }^{1}$ Since then other terms have emerged to describe the experience, such as "climate anxiety", "eco-angst" (Goleman), "environmental anxiety" (Pihkala), and "solastalgia" (Albrecht). ${ }^{2}$ The American Psychological Association has even identified a condition they call "eco-anxiety disorder", issuing a major report to characterize the "resounding chronic psychological consequences" related to how human beings around the globe process the climate crisis. ${ }^{3}$ According to Glenn Albrecht, who coined the term "solastalgia", he was attempting to name "the pain or distress caused by the loss of, or the inability to derive solace connected to the negatively perceived state of one's home environment". It exists when there is the "lived experience of physical desolation of home". ${ }^{4}$ Albrecht first applied the term solastalgia to his observations of the emotional well-being of people living in coal mining regions in eastern Australia, and it has since been applied to studies in the coal counties of eastern Kentucky, among persons facing

\footnotetext{
(Leff 1990).

(Goleman 2009; Pihkala 2018); Australian environmental philosopher Glenn Albrecht has published many articles and essays on this topic, but the most comprehensive treatment is in (Albrecht 2019). Albrecht, who coined the term solastalgia in the early 2000s, has developed a taxonomy of "illnesses" related to persons' awareness of the conditions of their biophysical environment. According to Albrecht, "Somaterratic" illnesses are those which threaten physical well-being when ecosystems are stressed or destroyed ("terratic" meaning, of course, "earth-related"), while psychoterratic illness is defined as "earth-related mental illness where people's mental well-being (psyche) is threatened by the severing of "healthy" links between themselves" and their environments. See (Albrecht et al. 2007). A Nexis search indicates that the term eco-anxiety appeared 785 times in popular news media in 2019, and an additional 341 times in the first two months of 2020.

(Clayton et al. 2017).

4 (Albrecht et al. 2007, p. 96).
} 
rising seas in the Marshall Islands, and to communities impacted by Hurricanes Irma and Harvey in the United States, among other places. ${ }^{5}$ Clearly, then, emotional distress related to environmental degradation is a global phenomenon: individuals and communities everywhere are experiencing a loss of solace - an inability to take comfort in the world around them, an inability to imagine a flourishing future for themselves or their ecosystems. Researchers on eco-anxiety and related concepts identify the following manifestations: grief, depression, PTSD, perceived loss of agency or ability to respond meaningfully, helplessness, despair, and loss of hope. In this essay I focus on the crisis of hope identified in all of this recent attention to eco-anxiety.

Terminology is important because it helps us identify and characterize what, exactly, is going on: terms like eco-anxiety and solastalgia name the felt emotional and psychological vulnerabilities humans face in the Anthropocene, recognizing despair or loss of hope as a key aspect of our vulnerability. Eco-anxiety can overwhelm individual and collective psyches in ways that immobilize capacities for action (because it is believed that no action one might take can matter) and for finding a sense of wholeness in living (because the loss of hope renders one unable to find meaning in life, in relationships, in the practice of faith, etc.). In this essay I argue that the emergence of eco-anxiety disorders requires re-imagined accounts of hope in light of the climate crisis in which we are now living. Theologians must render accounts of hope that are honest about the realities we face and that point toward ways to live with purpose, not relying on miraculous intervention. While eco-anxiety has gotten plenty of attention in popular media and in academic literature in the social sciences, social work, mental health, and medical fields, theologians, pastoral theologians, and spirituality scholars have yet to address it. ${ }^{6}$ Eco-anxiety and its attendant crisis of hope require wide-ranging responses, from the clinical to the political: in this essay I offer only one very narrow response as I reflect on the meaning of Christian hope in a time of climate crisis. Nevertheless, I believe that reflection on hope is a necessary intellectual resource that theologians must provide for people of faith grappling with how to live in these times. After surveying some recent popular works on the climate crisis and hope, I examine and critique two specifically Christian accounts of hope before arguing that any credible Christian account of hope in the Anthropocene must first embrace hopelessness. By hopelessness I mean accepting the reality of how deep the climate crisis actually is and that we are now at a point where it will not be reversed in a way that restores our planetary ecology to some former state. In conclusion, I will suggest three dimensions of a renewed account of hope.

\section{Hope in Recent Climate Crisis Literature}

A spate of books outlining the realities of climate crisis has appeared on popular bookshelves and best-seller lists in recent years. They bear ominous titles like The Uninhabitable Earth: Life After Warming; The Water Will Come: Rising Tides, Sinking Cities, and the Remaking of the Civilized World; The End of Ice; Learning to Die in the Anthropocene: Reflections on the End of a Civilization; Falter: Has the Human Game Begun to Play Itself Out?; and a revised version of Field Notes from a Catastrophe, to name just a few. ${ }^{7} \mathrm{~A}$ number of these works are structured similarly: they start by describing, usually in great forensic detail, the catastrophic future into which the planet is heading (indeed, into which we are already living to some degree), musing on extreme human vulnerability in such a future. However, after outlining the dire consequences of carbon-based global capitalism's ruinous effects on the planet, these treatments

\section{(Canu et al. 2017)}

6 While searches of terms like eco-anxiety and solastalgia produce hundreds, even thousands, of results on the databases Nexis and Academic Search Ultimate, a search of the American Theological Library Association (ATLA) database produces exactly one result for either term as of 28 February 2020.

7 (Wallace-Wells 2019; Goodell 2017; Jamail 2019, pp. 209-25; Scranton 2015; McKibben 2019; Kolbert 2015). I appreciate an anonymous reviewer pointing out that this list consists almost entirely of male authors; the reviewer suggested that the constructions of hope proposed by the authors I engage and critique here may be shaped by particular, and perhaps unhelpful, forms of masculinity. I regard this suggestion as very insightful and I am grateful; it recommends the importance of a gender-related analysis of this literature that I would like to take up in the future. 
go on to extend some account of hope, insisting that there is still time to change course and that we can avoid the worst outcomes. They express some confidence that humans can transform our politics, our economies, and our infrastructures in order to avoid the most extreme calamities, calamities they have just spent several chapters describing as inevitable.

For example, David Wallace-Wells begins his New York Times bestseller The Uninhabitable Earth with the now oft-quoted line: "It's worse, much worse, than you think". ${ }^{8}$ His chapter titles include "Heat Death", "Hunger", "Drowning", “Dying Oceans", "Unbreathable Air", "Economic Collapse”, etc. In the first half of the book Wallace-Wells cites scientific data and statistical projections, and shares anecdotes describing a future in which extreme heat, diminishing supplies of fresh water, rising seas, and global pandemics will result in widespread economic collapse, enormous numbers of refugees, and large scale human conflict. And yet, he claims in the second half of the book-somewhat remarkably, given the tenor of part I-that he is optimistic: "We found a way to engineer devastation, and we can find a way to engineer our way out of it". ${ }^{9}$ Considering the pros and cons of technologies like carbon capture and geoengineering, Wallace-Wells expectantly asserts that "we may conjure new solutions" not yet thought of. He holds out hope that societies will make political and economic choices and develop technologies that will mitigate the worst effects of climate change.

Australian environmental historian and writer Tim Flannery is a bit less apocalyptic than some other authors of these works and a bit more overtly hopeful in his book (which actually includes the word "hope" in the title): Atmosphere of Hope: Searching for Solutions to the Climate Crisis. Flannery, however, proceeds in much the same manner as Wallace-Wells and others. Flannery spends the first five chapters detailing our dire circumstances, addressing "The Waters of a Warming World", and "Ominously Acidic Oceans". Chapter four's title is framed as a question: "How are the Animals Doing?" The epigraph, however, gives away the answer: "We'll lose more species of plants and animals between 2000 and 2065 than we lost in the last 65 million years" (quotation from Paul Watson). ${ }^{10}$ Like Wallace-Wells, though, Flannery touts positive signs, possibilities, and technological solutions: coal use is declining, he notes somewhat cheerily; solar and wind energies are gaining ground; geoengineering and carbon capture might save the day. "I have mixed feelings about the future", admits Flannery. ${ }^{11}$ Nevertheless, he insists that we already have at our disposal the knowledge and the tools required to avoid a climate disaster. "Between deep, rapid emissions cuts and third way technologies, we can do it" $^{\prime \prime}$ Flannery confidently asserts near the end of the book. ${ }^{12}$

Not every book in this genre displays as much optimism, but many seem to minimize or mitigate the effects of the projections they report with their conclusions. They share scientific data that demonstrates catastrophic realities, and yet seemingly attempt to reassure readers that the worst will not necessarily happen. Their "hopes" are rooted in technological innovations and political leadership and will. Given current political and economic realities, however, it is difficult to imagine why these authors might hold out any hope that things are going to get better. Each year, more and more reports appear telling us that glaciers and the Antarctic ice shelf are melting more rapidly than previously thought, ocean temperatures are increasing more quickly than previously thought, the Great Pacific Garbage Patch is now more than twice the size of Texas, and $\mathrm{CO}_{2}$ levels rose again for the seventh consecutive year in 2018. As some of the authors note, more than half of the carbon pumped into the atmosphere from the burning of fossil fuels has been emitted in the last three decades: that is, roughly since the first Rio Summit or since Al Gore published Earth in the Balance. This means, as Wallace-Wells notes, that we have "now engineered as much ruin knowingly as we ever managed in ignorance". ${ }^{13}$

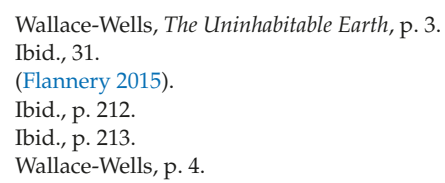


Global economic infrastructures remain highly fossil fuel dependent and carbon intensive. The world's political leaders display no inclination to meaningfully address our crisis. In fact, most of them continue to act as if there is no crisis, as illustrated by the "Arctic policy" announced by the United States in 2019 by Secretary of State Mike Pompeo. In a news conference held in Finland, Pompeo expressed excitement about the rapid melting of sea ice in the region. "The Arctic is at the forefront of opportunity and abundance", he said, noting the vast amount of untapped oil and natural gas, along with "an abundance of uranium, rare earth minerals, gold, diamonds, and millions of square miles of untapped resources, fisheries galore" which will become available as the ice melts. Rather than pondering the dire consequences of the melting Artic for the Earth's vulnerable poor-or even for people working and living in lower Manhattan or Hoboken-and appealing to international communities to join together in addressing this unfolding crisis, Pompeo touted only the new opportunities for travel, trade, and resource extraction opening up. ${ }^{14}$ The Secretary displayed not a hint of irony that extracting carbon emitting fossil fuels previously made inaccessible by the now melting ice will contribute to even further melting, warming, sea level rise, more climate refugees, more conflict over resources grown ever scarcer, etc.

In the face of a radical destabilization of the Earth's capacities to sustain life as we have known it for most of the history of civilization, the world's political and corporate leaders see only economic opportunity and the need to colonize even more space in the service of empires. Thus, the hope expressed by authors like Wallace-Wells and Flannery that we will find the political will and the technological innovations to pull back from the brink seem hollow. And, yet, we perpetually seek out reasons to hope: humans are fundamentally hoping creatures. ${ }^{15}$ Hope has to do with the future and involves an expectation that a good that is desired can be attained or achieved. And if we do not believe that a future awaits-a future that promises solutions to problems, improved living conditions, flourishing lives for humans and other creatures-then what motivation do we have to live into that future, much less do the hard work that addressing the perils of the Anthropocene requires?

\section{Christian Accounts of Hope}

In Christian thought, hope has long been regarded as a virtue. In fact, it is one of the three theological virtues. "And now faith, hope, and love abide", wrote the apostle Paul at the end of his well-known discourse on love found in chapter 13 of his first letter to the Corinthian church. Ever since, Christians have regarded these "virtues" as fundamental, even constitutive, of a person's relationship with God: that is, of the spiritual life. Thus, in response to the crisis of hope brought on by eco-anxiety, Christian theologians have a long history of reflection on hope from which to draw. Not all Christian accounts of hope, however, are necessarily helpful for living through the vulnerabilities with which climate crisis confronts humanity. In this section, I examine and critique two Christian accounts of hope, one classical and a more recent one by an ecotheologian, before considering some elements of a re-imagined account of Christian hope for the Anthropocene.

Thomas Aquinas's account of hope has been widely influential since he articulated it in the 13th century; we derive from it the notion of "theological virtues" (as opposed to "natural virtues"). In his Summa Theologica, Thomas explained that hope, as a natural passion, is "the desire for a future, difficult, yet possible good". ${ }^{16}$ As a theological virtue, Thomas locates hope in the will, as hope directs the will toward the good. Here, hope becomes a primary point of convergence for theology, spirituality, and ethics in Thomas's work, because the ultimate good, the arduous good, toward which hope leads us, is God, in Godself, toward union with God. Hope is for the enjoyment of God's presence. Further, this hope, as theological, is an infused virtue, meaning that it is not attainable through human efforts,

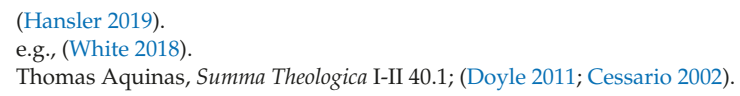


but that it is given by God. As such, hope acts as a "stable disposition" that enables one to "endure difficulties on the way to realizing the Good", ${ }^{17}$ a good realized fully only in the next life. Should one pursue a good that is easily attainable without struggle, they are displaying merely desire and not hope. Indeed, hope is understood to be a primary motivation for moral action. Despair, in this rendering, is a vice in that it is the will turning from the Good. "People who despair acknowledge that the object hoped for is, in truth, a good to be pursued", yet believe that it cannot be attained because it is too difficult. Because hope relies completely on the grace, mercy, and power of God, despair indicates a complete "absence of any transcendent hope in God's mercy and power". ${ }^{18}$ Further, just as hope is the source of all other virtues in orienting one's actions toward God, despair is "the source of other sins" in that it draws one away from moral action, denying "the infinity of God's goodness and mercy". 19

Although Aquinas's account of hope, only briefly treated here, is not directed toward an ecological ethic, its logic provides an interesting point for reflection in light of a climate chaos-related crisis of hope. If the hope for a better future, as expressed by some environmentalists and progressive politicians, is grounded in faith in technologies and the human willingness to adapt and change in order to avoid disaster, the source of hope for many Christians lies beyond human capacities. In Aquinas's account of hope, it is founded on a transcendent metaphysical source. That is, it relies on a transcendent God to act on the human will to keep it moving toward a divinely established end-the beatific vision or salvation. Of course, the will may resist, but it will be resisting the inevitable fulfillment of nature and history ordained by God. ${ }^{20}$ While Aquinas's account focused on the person and on a non-material fulfillment, it takes place, as environmental philosopher Andrew Fiala notes, "within an account of creation that views history as progressive and linear. Theological hope involves reflection upon what was lost in the beginning of history and expectation about what can be attained in its end". ${ }^{21}$ This account could suggest that our currently unfolding ecotastrophe provides opportunities for spiritual growth and transformation through the practice of hope, anticipating a future creation restored to its primordial wholeness or fulfilled into some at-present unknown flourishing. ${ }^{22}$

Just as Aquinas's account of hope for the human person relies on a transcendent, metaphysical source, many contemporary Christian eco-theological accounts of hope for "creation" rely, too, on the expectation of a transcendent future that comes about as the gift of a transcendent God whose power ultimately overcomes all forms of oppression, injustice, cruelty, and decay. The second example of Christian hope I explore is articulated by the Lutheran ecotheologian Cynthia Moe-Lobeda, who asserts, as the starting point for her account of hope in the Anthropocene, "Nothing is surer, no truth stronger than this breath-taking claim of Christian faith: that God-the Light of Life, the creating, liberating, healing, sustaining Source-loves this world and each of us with a love that will not diminish, a love more powerful than any other force in heaven or earth". ${ }^{23}$ In musing on where one might find the motivation and "moral-spiritual power" to resist despair and hopelessness in the face of colossal and intractable systems and structures that perpetuate economic and ecological injustice, she points to the resurrection of Jesus Christ, which determines that "God's life-saving, justice-seeking love is stronger than all else. In some way that we do not grasp, the last word is life raised up out of death. God 'will not allow our complicity in this evil to defeat God's being for us and for the good of all creation'". ${ }^{24}$ Part of the appeal of her account is that it locates hope for an ecological future and motivation for action to resist structural evil, climate injustice, and ecological catastrophe squarely within the Christian prophetic and eschatalogical framework of the coming reign of God, the divine sovereign who is

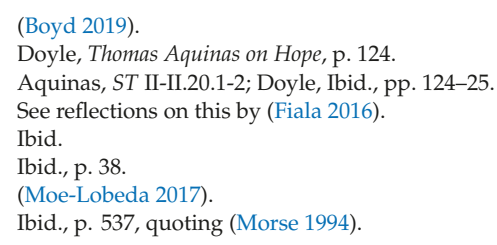


making and will make things right. Further, she points to resources and practices in the Christian tradition that seem to hold promise for motivating actions that might contribute to planetary healing. Her ethical vision consistently urges Christian people to respond with vigorous moral action as "God's embodied presence in the world" (quoting Bonhoeffer). "The destiny of creation is abundant life for all", she writes. Many people are paralyzed in what she calls a "moral inertia in the face of economic and ecological violence" which she attributes to "a lack of hope that it can change". However, "the cross and the resurrection promise otherwise. They testify that in the face of death and destruction, God's life-bringing power prevails. Soul-searing, life-shattering destruction and death are not the last word". In the end, Moe-Lobeda declares that we must trust God to work this out: "While the forces of evil are fierce and virulent, the force of good-known in Christian tradition as divine love-will ultimately triumph ... God, not humans, can and will save the world". ${ }^{25}$

Theologians like Moe-Lobeda operate within the moral and theological frameworks of particular Christian traditions, attempting to render accounts of hope that resonate with historic Christian teaching. This is an admirable strength of her work: it is recognizable to the tradition's adherents and contains rhetorical energy. However, I do not believe it is adequate to address our current crisis of hope because it relies too heavily on a God conceived as an all-powerful sovereign who will ultimately intervene to set things right.

Some critics of traditional religious accounts of hope, like environmental philosopher Michael Nelson, suggest that hope itself acts as a dangerous and counterproductive distraction, especially in its transcendental forms, working against motivating people to engage in rigorous action to combat climate change and its impacts. ${ }^{26}$ Nelson says that such hope is a "placebo" that simply establishes the conditions for disillusionment, if hope is understood as promoting the expectation of a "restored creation". Accounts like Aquinas's, which relativize "secular" or "temporal hopes" in relation to the ultimate "eternal hope" in God, could be viewed as diminishing motivation for participation in life giving-moral action vis-à-vis the planet. ${ }^{27}$ Accounts of hope like Moe-Lobeda's seem to minimize what science tells us about our planetary future (and present) in favor of a projected future in which we must trust God, an omnipotent divine sovereign, to take care of us in order to avoid a catastrophic future. Indeed, Whitney Bauman has critiqued accounts of what he calls "the Omni-God, creator ex nihilo" who "has been used as a transcendent space for hope (in the form of eschatological new creations) and blame (in the form of theodical questions)". One of Bauman's points is that this theology of transcendence "becomes a space of denial of responsibility for human actions". ${ }^{28}$ He goes on to argue that this denial is actually a denial of the reality of how the planet has evolved and how it works, as it chooses to embrace a transcendent and idealistic notion of harmony (one that will be restored by "Omni God") rather than an understanding of how things actually are. This serves to blur our vision about what humans are responsible for and what we are not: in the end, both social and moral "evils" (such as poverty) and "natural evils" (such as predator-prey relations and death) will be eliminated by "Omni God". I would add that this theology of transcendence denies the scientific accounts of what is actually happening to the planet now and what possibilities for renewal we are foreclosing.

Finally, both the secular writers treated in Section 2, who encourage their readers to choose hope, and the theologians who, like Aquinas, identify despair as a sin, ignore what research on eco-anxiety indicates about human nature. The former (i.e., those who believe we will think, invent, and engineer our way out of the climate crisis) attribute a loss of ecological hope to a failure of will and imagination, while the latter (the theologians) view it as a failure of faith and morality. Both of these attributions fail to grapple with the very real psychic and emotional tolls that the Anthropocene takes on the

25 (Moe-Lobeda 2013).

26 (Nelson 2016).

27 Doyle argues that while Aquinas's account of hope could be viewed this way, it should not be if read properly. Doyle, Thomas Aquinas on Hope, pp. 120-33.

28 (Bauman 2009). 
lived experience of persons and communities. If what Wallace-Wells, Flannery, McKibben, and others outline in the first parts of their books is true, then most talk of hope amounts to whistling in the hurricane. Despair, anxiety, depression, and loss of hope actually seem to be reasonable responses. Further, identifying these responses as sinful seems ignorant and cruel. Thus, what is called for now is a radical rethinking of what hope means in Christian terms. What might a more adequate account of Christian hope for the Anthropocene look like?

\section{Embracing Hope(lessness)}

In a recent New Yorker essay entitled "What if We Stopped Pretending?", Jonathan Franzen writes, "If you care about the planet, and about the people and animals who live on it, there are two ways to think about this. You can go on hoping that catastrophe is preventable, and feel ever more frustrated or enraged by the world's inaction. Or you can accept that disaster is coming, and begin to rethink what it means to have hope". ${ }^{29}$ Following Franzen's second way, I suggest that the first step toward reimagining Christian hope in the Anthropocene is to stop pretending and to embrace hopelessness. I am borrowing the notion of "embracing hopelessness" from Christian ethicist Miguel De La Torre. ${ }^{30}$ In his recent book on hopelessness, writing to the pain and suffering of billions of the world's poor who experience the crushing burden of colonial and neo-colonial exploitation and oppression, De La Torre asserts that "hope is possible when privilege allows for a future". He explains that hope, "as a middle class privilege, soothes the conscience of those complicit with oppressive structures, lulling them to do nothing except look forward to a salvific future where every wrong will be righted and every tear wiped away, while numbing themselves to the pain of those oppressed, lest that pain motivate them to take radical action". De La Torre goes on to declare that "The first step toward liberation requires the crucifixion of hope ... the realization that there is nothing to lose becomes a catalyst for action". ${ }^{31}$ I acknowledge that, as one who enjoys a great deal of "middle class privilege", the worst impacts of climate change will fall upon those of whom De La Torre writes while others of us will fare better. However, the time is approaching when fewer and fewer will fare well-even many of the privileged-as we have less and less to lose, as the losses mount. Although De La Torre's work is not about the climate crisis per se, I take his suggestion to embrace hopelessness as suggestive-even generative-for a reimagined account of Christian hope in the Anthropocene.

To embrace hopelessness as a first step in reimagining hope means to accept that we are in the midst of an utterly disorienting, overwhelming, and intractable crisis and that the conditions that threaten life and well-being on Earth are going to get worse. To release a false sense of hope that things are going to get fixed-by political will, technology, or an "Omni God"- - provides clarity and a more realistic set of expectations. Any credible account of hope will begin with truth-telling, which includes accepting what climate scientists are telling us about the future unclouded by false hopes and coming to terms with human responsibility for our current condition. ${ }^{32}$ Roy Scranton's Learning to Die in the Anthropocene is an exception among the titles addressed earlier in that he does not try to peddle optimism that things are going to get better, that there will be a last minute rally to avoid disaster. Scranton writes that "The greatest challenge we face is a philosophical one: understanding that this civilization is already dead". ${ }^{33}$ Scranton draws on his time as a soldier in Iraq to argue that the human future depends on accepting the fact that our civilization is already in its death throes, just as he had to

\footnotetext{
(Franzen 2019).

(De La Torre 2017).

Ibid., pp. 5-6.

Truth-telling about climate crisis will also involve persons in the world's most industrialized and developed nations-i.e., the Western colonial powers - to acknowledge their greater complicity in bringing about the crisis and to take steps to aid persons and communities that have lesser responsibility for the crisis but will suffer disproportionate impacts. Theologically, we would call this confession, repentance, and restitution.

33 Scranton, Learning to Die in the Anthropocene, p. 23.
} 
come to terms with the inevitability of his own death, not just in order to survive, but also so as to function in the midst of war. ${ }^{34}$

The Jesuit priest Walter Burghardt famously described contemplation as a "long loving look at the real". For Burghardt, human wholeness emerges from a willingness to allow one's whole self to respond to what is most real in the world. This includes the appreciation of beauty and virtue, but it also involves gazing, clear-eyed and lovingly, on the broken and the tragic. The "real" includes war, poverty, disease, and climate chaos. "Contemplation does not always summon up delight", warned Burghardt. It also involves confession and grief. ${ }^{35}$ If we are to live into the future in the best ways possible, we will have to embrace a faith, hope, and love that are capable of acknowledging the realities of our diminishments and capable of helping us to face the world as it is, the world we have made. As the spiritual writer Margaret Swedish wrote several years ago, faith must be able to "encompass our ecological crisis, provide it with content and meaning", insisting that "we need a spiritual space large enough to contain all of our fears and hopes, our questions and our bewilderment". 36 Any account of hope that dismisses, discounts, or cannot face our realities or include our anxieties will, indeed, be a placebo.

A second aspect of a credible account of hope in the Anthropocene is an expanded notion of the experience of God or the Sacred. Swedish writes that we need "Faith that can enlighten and inform all this disturbing news by providing a framework of meaning for it, a place for an experience of the Divine within it". ${ }^{37}$ The Christian quest for the Sacred through much of history has largely sought God outside of or above the natural world. The logic of that quest has caused humans to attempt to extract ourselves from the rest of the world. The dualisms of matter/flesh and spirit, sacred and profane, heaven and earth, Creator and creation that run throughout the history of Western Christianity have served to desacralize the world of "nature" and located the quest for God in an otherworldly sphere and in the realm of ideas or reason. As many scholars have shown, the quest for God outside of or apart from the earthly has contributed to the establishment of hierarchies in which, in the earthly sphere, humans have established themselves at the top, hovering above the rest of a world seen as external to humanity. ${ }^{38}$ Such a view of the world understood "nature" to be a resource to subjugate and exploit to the fullest. Such a view has greatly contributed to the crisis we now face.

There are many Christian-and other religious and non-religious - accounts of spirituality that find the sacred embedded within the world; a new account of hope needs this. Partly, this means acknowledging that we are a part of a larger whole and celebrating our connection to a vast, remarkable, mysterious, and still vital world. As Dahr Jamail writes, it means being present-fully alive to-what remains of beauty and wholeness, even as we grieve what we are losing. ${ }^{39}$ It also means learning to experience the sacred in "nature" or "nature" as sacred, becoming comfortable with that, and learning to speak about that experience vividly. Many examples of this are available to us. Sallie McFague has offered a model of theological language along these lines, naming the Earth itself as "the body of God". That is, she understands God as embodied in the universe itself, and all bodies on the planet as incarnations of God. ${ }^{40}$ Theologian Mark Wallace has written eloquently of his "palpable experience of

34 Ibid., pp. 13-27.

35 Dahr Jamail's The End of Ice, like Scranton's work, is an exception to the literature on climate crisis cited in this essay. Reporting on his journeys around the globe observing the effects of climate change on glaciers, coral reefs, and indigenous cultures in the Arctic, Jamail also refuses to promote optimism that we might restore what has been lost. Rather, in an elegiac work, Jamail encourages us to grieve what we are losing, to give ourselves to the work of repair without expecting a particular outcome, and, like Scranton, to ask ourselves who we now want to become and how we want to live in this time. (Jamail 2019). There is much literature on grief as a response to ecological loss, both academic and theological, thus I will not treat it here.

36 (Swedish 2008).

37 Ibid.

38 e.g., (Merchant 1980; Plumwood 1993, 2002).

39 Jamail, The End of Ice, pp. 214-15.

40 (McFague 1993). 
God in the Earth", swimming in a Mississippi coastal river as a child and hearing an ancient, mournful song of Pascagoula legend in the water. "The river was a site of numinous powers, greater than myself, that both transcended and interpenetrated the everyday world of boyhood activity I normally inhabited", he recalls. "God, I sensed, was in the river, but God was also beyond the river". ${ }^{41}$ This childhood memory serves as the basis for Wallace's book on the relationship between God and the world. Finally, Lisa Dahill gives us a wonderful example of speaking about finding God in the world in her address to the Society for the Study of Christian Spirituality a few years ago. Describing her own spiritual transformation, Dahill tells how her discernment led her outside of traditional modes of Christian discourse, practice, and experience, literally to the outside- to the woods, the creeks, the wind-as the space of sacred encounter. She writes, "Jesus is dissolved: all that's left is the wind ... the literal wind, the outdoor wind breathed from trees and cold fronts that fills my lungs" ${ }^{42}$ Christian hope in a time of climate crisis must relinquish ideas of a God radically separated from this world who is expected to intervene from outside to repair the damage we have done. It must relocate notions of the experience of God from transcendent ether-worlds to this Earthy-world so that our conception of the encounter with the sacred is radically immanent.

Finally, a re-imagined hope emerging from an embrace of hopelessness will see virtuous action on behalf of the Earth and its inhabitants as a good in itself rather than as a means to an end. Many environmental ethicists cling to consequentialist accounts because they insist that motivation to action requires outcomes that people can anticipate. Those who research eco-anxiety report that a perceived loss of agency and lack of belief that one's actions have any meaning in the midst of a crisis of such overwhelming proportions is one of the underlying causes of feelings of despair. However, others argue that relinquishing hopes that our virtuous actions will save the planet from ruin means that we are freeing ourselves to engage in life-giving practices.

The environmental activist and writer Derrick Jensen muses, "When you give up on hope, you turn away from fear". Jensen goes on to argue that hope in the traditional sense allows the people, institutions, and ideas that are wrecking the planet to maintain control. "When you quit relying on hope, and instead begin to protect the people, things, and places you love, you become very dangerous indeed to those in power". When we realize the agency we do have, reasons Jensen, "we no longer have to 'hope' at all. We simply do the work". ${ }^{43}$ Here Jensen seems to echo De La Torre's suggestion that releasing hope spurs action.

Scranton argues that our approach to the Anthropocene has to do with who we want to be-our humanity. He writes: "The conceptual and existential problems that the Anthropocene poses are precisely those that have always been at the heart of humanistic inquiry: What does it mean to be human? What does it mean to live? What is truth? What is good? In the world of the Anthropocene, the question of individual mortality —What does my life mean in the face of death?-is universalized" ${ }^{44}$ Scranton argues that our circumstances call for a "new humanism", a moral and philosophical reckoning in which humans accept responsibility for our contributions to geo-planetary catastrophe and look to our cultural heritages - the philosophical, literary, and artistic inheritance of the world's many cultures-for wisdom about how to live (and die) in this altered world.

Theologically, Paul Tillich's reflections on hope offered in the face of the threat of nuclear war are instructive on this point. Genuine hope, for Tillich, must be distinguished from utopian expectations, and that distinction lies in the grounds of hope that are evident in the present. Utopian expectations-i.e., expectations of a dramatic reversal in planetary climate chaos-have no basis in the present. However, according to Tillich, "the basis for genuine hope is that there is something present of that which is hoped

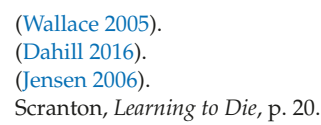


for, as in the seed of something of the coming plant is present". ${ }^{45}$ These "seeds of hope" consist of any acts of love, justice, or mercy we might manage; they are the manifestations of hope in themselves. Tillich warned that we should not understand the goal of history as moving in linear fashion toward some state of future perfection or restoration, but that we must work toward what is possible in every given circumstance: our struggle is against "the forces of evil, old ones and new ones, which arise in each period in a different way". However, "every victory, every particular progress from injustice to more justice, from suffering to more happiness, from hostility to more peace, from separation to more unity anywhere in [hu]mankind, is a manifestation of the eternal in time and space". Tillich identifies this as the coming of the reign of God. Planting "seeds of hope" by acting for the sake of acting realizes God's reign in the moment, for each seed contains within it a trace of that for which one hopes. ${ }^{46}$ Thus, without any illusions that actions on behalf of justice, community, and sustainability will bear results, we engage in them in order to become more human and to create space for the experience of God's reign in the present. Hope becomes an enacted phenomenon rather than an idealistic projection.

Theological and philosophical reflections on the nature of hope will not, by themselves, overcome the crushing angst, fear, and despair of those who experience eco-anxiety. However, releasing unrealistic and overly optimistic notions of hope that rely on technological innovation or a divine sovereign to intervene can create space for clarity and free us from paralyzing anxiety and fear. The first step to imagining a credible, generative account of Christian hope in the Anthropocene is to embrace hopelessness, not as a vice but as a virtue. When we no longer cling to delusional notions of restoration or rescue from outside, we do the work that points the way beyond despair, seeking wisdom to live more humanly.

Funding: This research received no external funding.

Conflicts of Interest: The author declares no conflict of interest.

\section{References}

Albrecht, Glenn. 2019. Earth Emotions: New Words for a New World. Ithaca and London: Cornell University Press. Albrecht, Glenn, Gina-Maree Sartore, Linda Connor, Nick Higginbotham, Sonia Freeman, Brian Kelly, Helen Stain, Anne Tonna, and Georgia Pollard. 2007. Solastalgia: The Distress Caused by Environmental Change. Australasian Psychiatry 15: 97. [CrossRef] [PubMed]

Bauman, Whitney. 2009. Theology, Creation, and Environmental Ethics: From Creatio Ex Nihilo to Terra Nullis. New York: Routledge, p. 164.

Boyd, Craig. 2019. The Thomistic Virtue of Hope in Tolkein's Leaf by Niggle. Christian Scholar's Review 48: 140.

Canu, Will H., John Paul Jameson, Ellen H. Steele, and Michael Denslow. 2017. Mountaintop Removal Coal Mining and Emergent Cases of Psychological Disorder in Kentucky. Community Mental Health Journal 53: 802-10, See Albrecht, Earth Emotions, pp. 27-61. [CrossRef] [PubMed]

Cessario, Romanus. 2002. The Theological Virtue of Hope. In The Ethics of Thomas Aquinas. Edited by Stephen J. Pope. Washington, DC: Georgetown University Press, pp. 232-43.

Clayton, Susan, Christie Manning, Kira Krygsman, and Meighen Speiser. 2017. Mental Health and Our Changing Climate: Impacts, Implications, and Guidance. Washington, DC: American Psychological Association and ecoAmerica.

Dahill, Lisa. 2016. Into Local Waters: Rewilding the Study of Christian Spirituality. Spiritus 16: 146. [CrossRef] De La Torre, Miguel. 2017. Embracing Hopelessness. Minneapolis: Fortress Press.

Doyle, Dominic. 2011. The Promise of Christian Humanism: Aquinas on Hope. New York: Crossroad/Herder and Herder, pp. 72-80.

Fiala, Andrew. 2016. Playing a Requiem on the Titanic: The Virtue of Hope in the Age of Ecological Calamity. In Ecology, Ethics, and Hope. Edited by Andrew T. Brei. Lanham: Rowman and Littlefield, pp. 37-38.

45 (Tillich 1990). Emphasis mine.

46 Ibid., pp. 188-89. 
Flannery, Tim. 2015. Atmosphere of Hope: Searching for Solutions to the Climate Crisis. New York: Grove Press, p. 43. Franzen, Johnathan. 2019. What If We Stopped Pretending? The New Yorker. September 8. Available online: https://www.newyorker.com/culture/cultural-comment/what-if-we-stopped-pretending (accessed on 9 September 2019).

Goleman, Daniel. 2009. The Age of Eco Angst. New York Times. September 27. Available online: https://opinionator.blogs.nytimes.com//2009/09/27/the-age-of-eco-angst/ ?fbclid=IwAR3rgTX5vAh3NsCPqiwzE14A5g2OivJALE_WOmbu1sRZ5WLnhlE_DHDYFo0 (accessed on 1 February 2020).

Goodell, Jeff. 2017. The Water Will Come: Rising Tides, Sinking Cities, and the Remaking of the Civilized World. Boston: Back Bay Books.

Hansler, Jennifer. 2019. Pompeo: Melting Ice Presents New Opportunities for Trade. Available online: https://www.cnn.com/2019/05/06/politics/pompeo-sea-ice-arctic-council/index.html (accessed on 7 May 2019).

Jamail, Dahr. 2019. The End of Ice: Bearing Witness and Finding Meaning in the Path of Climate Disruption. New York: The New Press.

Jensen, Derrick. 2006. Beyond Hope. Orion Magazine. May 2. Available online: https://orionmagazine.org/article/ beyond-hope/ (accessed on 15 January 2020).

Kolbert, Elizabeth. 2015. Field Notes from a Catastrophe: Man, Nature, Climate Change, rev. ed. New York: Bloomsbury USA.

Leff, Lisa. 1990. Ecology Carries Clout in Anne Arundel. Washington Post. August 5 . Available online: https://www.washingtonpost.com/archive/local/1990/08/05/ecology-carries-clout-in-anne-arundel/ a01f0325-e1bf-4f25-b180-65bc4540ef0c/ (accessed on 26 February 2020).

McFague, Sallie. 1993. The Body of God: An Ecological Theology. Minneapolis: Fortress, p. 157.

McKibben, Bill. 2019. Falter: Has the Human Game Begun to Play Itself Out? New York: Henry Holt and Co.

Merchant, Carolyn. 1980. The Death of Nature: Women, Ecology, and the Scientific Revolution. New York: Harper Collins.

Moe-Lobeda, Cynthia. 2013. Resisting Structural Evil: Love as Ecological-Economic Vocation. Minneapolis: Fortress, pp. 154-56.

Moe-Lobeda, Cynthia. 2017. Climate Injustice, Truth-telling, and Hope. Anglican Theological Review 99: 531.

Morse, Christopher. 1994. Not Every Spirit: A Dogmatics of Christian Disbelief. Valley Forge: Trinity Press International, p. 249.

Nelson, Michael. 2016. To a Future Without Hope. In Ecology, Ethics, and Hope. Edited by Andrew T. Brei. Lanham: Rowman and Littlefield, pp. 129-30.

Pihkala, Panu. 2018. Eco-Anxiety, Tragedy, and Hope: Pscyhological and Spiritual Dimensions of Climate Change. Zygon 53: 545-69. [CrossRef]

Plumwood, Val. 1993. Feminism and the Mastery of Nature. London and New York: Routledge.

Plumwood, Val. 2002. Environmental Culture: The Ecological Crisis of Reason. London and New York: Routledge.

Scranton, Roy. 2015. Learning to Die in the Anthropocene: Reflections on the End of a Civilization. San Francisco: City Lights Books.

Swedish, Margaret. 2008. Living beyond the End of the World: A Spirituality of Hope. Maryknoll: Orbis, pp. 160-61. Tillich, Paul. 1990. Theology of Peace. Edited and introduced by Ronald Stone. Louisville: Westminster/John Knox, p. 179.

Wallace, Mark I. 2005. Finding God in the Singing River: Christianity, Spirit, Nature. Minneapolis: Fortress, pp. 1-2. Wallace-Wells, David. 2019. The Uninhabitable Earth: Life after Warming. New York: Tim Duggan Books.

White, Carol Wayne. 2018. Re-Envisioning Hope: Anthropogenic Climate Change, Learned Ignorance, and Religious Naturalism. Zygon 53: 578. [CrossRef]

(C) 2020 by the author. Licensee MDPI, Basel, Switzerland. This article is an open access article distributed under the terms and conditions of the Creative Commons Attribution (CC BY) license (http://creativecommons.org/licenses/by/4.0/). 

Article

\title{
Grave Reminders: Grief and Vulnerability in the Anthropocene ${ }^{t}$
}

\author{
Lisa H. Sideris
}

Department of Religious Studies, Indiana University, Bloomington, IN 47405, USA; 1sideris@indiana.edu

† This essay is dedicated to students in my Spring 2020 seminar on "Extinction" at Indiana University.

Thank you for reading and discussing sometimes painful material on species death and environmental grief with me (until a pandemic, whose origins almost certainly lie in humans' destruction of the natural world, isolated us from one another). I fully acknowledge that my generation has failed you.

Received: 11 May 2020; Accepted: 9 June 2020; Published: 16 June 2020

\begin{abstract}
This essay builds upon recent work in the environmental humanities, and that of various writers and journalists, on the emerging topic of environmental grief and mourning. I consider a spectrum of responses to Anthropocene-era crises like climate change and extinction, with particular emphasis on how we are oriented toward the past and the future. These perspectives range from positions that explicitly reject grief and vulnerability, to voices urging us to embrace grief as part of an essential moral and spiritual environmental practice. At one end of the spectrum, we find articulations of what I call climate humanism, a style of response focused on defending and perpetuating human civilization in the midst of environmental crisis, but with little or no explicit concern for the broader web of living and dying beings. For climate humanists, to grieve for the past and its mistakes is to halt progressive, optimistic movement into the future. At the other end of the spectrum, we find scholars and writers who take profound grief, and sustained reflection on death and loss, as the starting point for genuine, transformative change and the possibility of hope. Drawing on this range of responses to environmental threats and losses, I endorse narratives that ground themselves in the past, in all its surprises and mistakes, as a vital resource and repository for moving hopefully and purposefully into the future. Moral, religious, and religious-like dimensions of environmental grief (or its denial) are recurring themes throughout, and many crucial insights are found in scholarship outside of religious studies.
\end{abstract}

Keywords: grief and mourning; hope; Anthropocene; climate change; extinction; climate humanism

"We are witnesses, and as we probe the ethics of relation and substance, perhaps working our way toward the uncertainty of a quantum god, we may yet engage with the wider gravity of keeping faith in the midst of devastation"-Deborah Bird Rose, Wild Dog Dreaming. (Rose 2011, p. 107)

I am not an optimist by disposition. For precisely that reason, I have often sifted through, and mostly found wanting, many narratives of so-called hope in the so-called Anthropocene. ${ }^{1}$ This essay constitutes a meditation on-perhaps more than an argument for-the power and moral significance of grief and mourning in orienting us properly toward an uncertain and perilous future. I explore a spectrum of responses to the current environmental crisis, with particular attention to issues

1 In much of what follows, I treat climate change and the current extinction crisis as a shorthand for the Anthropocene concept that humans have become a force reshaping the planet on a geological scale. My focus here is less on the implicitly religious nature of the Anthropocene itself than on grief and mourning as responses to it. For a discussion of the former and of the problematic nature of the Anthropocene concept itself, see (Sideris 2016). 
of climate change and species extinction. Some of these responses adopt-to varying degrees-a kind of defensive humanist posture that privileges human civilization and seeks to insulate it, to fortify it, against the shocks of climate change and related disasters. Wittingly or not, this defensive stance implicitly renders Earth and nonhuman beings as something less than animate and living, and in doing so, disavows nonhuman nature as truly mournable. Other voices invite us into grief and vulnerability as potentially transformative, contemplative states that reconnect us with human and nonhuman others, and with our own painful history of losses and failures. My own sensibilities incline me toward the latter set of responses, and their potential to humanize us in the midst of crisis. These voices, I believe, contain clues about how to remain upright and forward-facing, how to carry on in the most basic sense of putting one foot in front of the other, when the future is almost unimaginable and the past seems somehow irretrievable, or simply irrelevant to the present situation.

The stories we tell about hope and loss are more important than ever if we aspire to make the "Age of Humans" a little more humane. An unwillingness or inability to mourn for the broader spectrum of life bespeaks a worrisome evasion of responsibility for environmental harms. Building upon existing scholarship in the environmental humanities and the work of contemporary writers and journalists, I affirm practices and perspectives that contain somber yet hopeful messages about the complex ways in which the past can orient us toward the future, in contrast to progressivist narratives urging us to relinquish the past and its missteps. By weaving together various narrative strands, ranging from contemporary stories of climate collapse, political action, and spiritual practice, to longstanding myths about death and loss, I consider the value of consciously attending to death, mourning, and loss as a step toward moral reckoning and meaningful change. ${ }^{2}$ The story of a small Icelandic glacier, and its recent death from climate change, presents an especially compelling resource for reflection on these interlocking themes. But first, we must consider how and why environmental grief often seems strangely muted or suppressed.

\section{Denial and Grievability}

Some of the most important insights regarding environmental hope and grief are currently to be found in nontraditional sources, such as podcasts, blogs, and online news stories. These indicate a somewhat spontaneous upsurge in grief and mourning in the face of climate change, extinction, and the Anthropocene generally. ${ }^{3}$ Climate protests like Extinction Rebellion are beginning to attract attention from academics and journalists alike, and recently some scholars have analyzed the ritual dimensions, and the religious commitments and overtones of these movements (Skrimshire 2019). On the whole, however, scholarship in religious studies and the broader humanities has been somewhat slow to register outpourings of environmental grief and mourning. "Despite the commonality of experiencing negative or emotional responses to environmental degradation," Ashlee Cunsolo notes, "ecological losses do not appear in broader public and academic discourses concerning climate change-as though animal, vegetal, and mineral bodies are somehow constituted to be ungrievable in these broader narratives" (Cunsolo 2017, p. 170). While this situation is changing, some notable gaps in the literature remain. Willis Jenkins observes, for example, that while theologians and religion scholars have addressed nearly every facet of the environmental crisis in recent decades, almost none have paid attention to human-caused extinction, and particularly mass extinction, even though these concepts

2 Throughout this essay, I draw primarily from narratives of the Eurowestern world, with regard both to stories of loss and those with a progressivist future orientation. My critical commentary, therefore, is not intended to encompass all cultures and histories, nor to suggest some homogenized human "we." Many cultures would not recognize Western linear notions of the past, present, and future. However, certain features and experiences of being human — grief, death, hope, and finitude—do have some general relevance as part of the human condition, however they are dealt with across cultures or religions.

3 An internet search for the terms "environmental grief" and "ecological grief" turns up numerous recent sources, including several devoted to the often private grief of climate scientists. The term "ecological grief" warrants a Wikipedia page (https://en.wikipedia.org/wiki/Ecological_grief). 
have permeated human consciousness longer than issues like climate change (Jenkins n.d.). Might there be a denial of death at work?

Currently, humanities scholarship that does address extinction often comes from fields of study adjacent to religious studies, but, as with Anthropocene narratives generally, these stories exhibit implicit or thinly secularized religious overtones. Like discourse on the Anthropocene generally, discussions of extinction, and of the fascinating and troubling efforts to de-extinct species, often entail an outright rejection of tragic or elegiac moods, in favor of upbeat narratives that aggrandize the human species. In Imagining Extinction, Ursula Heise notes the peculiar way in which humans' current impacts on the environment are presented in tones of "awed celebration" and "wide-eyed optimism" at the possibility of a planet reshaped by humans (Heise 2016, p. 206). There is a distinctly "forward-facing" orientation to these narratives, a glorification of humans as creatures who plunge ahead rather than looking over their shoulder at the mistakes of the past. Rather than serve as confirmation of past and present failures, the Anthropocene and associated extinction events are recast as the seeds of a new, exciting, and forward-looking environmentalism. This orientation is apparent, for example, in Diane Ackerman's appraisal of our Anthropocene moment in The Human Age. Ackerman sees humans as having arrived at a critical juncture - a great turning - where the deep past meets a tantalizing future. "Behind us eons of geological history, ahead a mist-laden future, and all around us the wonders and uncertainties of the Human Age." Uncertainties notwithstanding, we are now positioned to take control of that future, she believes, for humans are wonder-workers and dreamsmiths. "What a marvel we have become" (Ackerman 2015, p. 308).

Even Heise, who is skeptical of the mournful, elegiac mode of environmental storytelling, finds this overtly sanguine, future orientation somewhat puzzling. Regarding de-extinction in particular, optimism about its potential to rewrite the story of environmental decline depends on embracing de-extinction "as a fascinating biotechnological experiment that might play a role in creating future ecosystems," rather than restoring those of the past (Heise 2016, p. 211, my emph.). Similar sentiments are echoed by some in the so-called ecomodernist or ecopragmatist camp such as tech enthusiast, entrepreneur, and de-extinction advocate Stewart Brand, who urges: "Don't mourn, organize" (Brand 2013). Environmental and conservation movements, Brand laments, have unwisely "mired themselves in a tragic view of life," forever fixating on the mistakes of the past. If the extinction of the passenger pigeon "broke the public's heart," Brand suggests, then the pigeon's revival through technologies of de-extinction might well "shake them out of it." Moreover, such a project could be "fun," Brand argues. "Could improve things. It could, as they say, advance the story" —a progressive and hopeful story to overwrite the tired declensionist narrative (qtd in Rich 2014). Broken hearts can be mended by cutting-edge technology.

So, again: why the stubborn resistance to mourning? Whence the injunction against looking backward, toward the past and its (sometimes heartbreaking) lessons? Grief is not merely protracted sadness, and the particular features of environmental grief may make it especially difficult to confront and process. Grief and mourning are responses to a world that has been radically transfigured. As Nancy Menning argues, environmental loss is complex, owing to the intermingling of grief with guilt for our own complicity, and perhaps anger at the wrongdoing, or indifference, of others. "We are often complicit in these losses, if only by virtue of living in the Anthropocene... Guilt entwines with sorrow, complicating the grieving process" (Menning 2017, pp. 39-40). Moreover, grief over issues like climate change is somewhat unique in that it is unlikely to lessen over time: "because of time-lags in the climate system, things will get worse for a long time to come, whatever we do" (Read 2019). On some accounts, for grief to do its work-for its transformative power to effect change in the mourner that reflects the magnitude of the loss - there must be a genuine reckoning with the irreplaceable nature of what is lost. Moving too quickly to closure, or seeking something new or different to replace the loss, 
may distort the grieving process or obstruct its transformative work. ${ }^{4}$ For example, efforts to de-extinct species may express an impulse to replace what was lost, and thereby short-circuit the process of grief and its potential to catalyze change. Where environmental mourning is tinged with other complex or unpleasant responses, opportunities to confront these emotions through commemorative rituals or funerary rites may help to spark change - the kind of individual and collective transformation that might mitigate similar losses in the future (Hance 2016). ${ }^{5}$ On the other hand, the uncomfortable mix of emotions can easily engender avoidance of grief.

Other factors may contribute to evasion and denial. In his commentary on religionists' lack of attention to the topic of extinction, Jenkins suggests that extinction sticks in the craw for human exceptionalists. "Making good on human exceptionalism," he writes, "perhaps seemed to require staying silent as Passenger Pigeon, Heath Hen, Ivory-billed Woodpecker, Bald Eagle, and California Condor fluttered at death's door" (Jenkins n.d., p. 5). Even Christian hymns and sermons attesting to divine attention to the sparrow serve only to reinforce our conviction that if God takes notice of so lowly a creature, God's concern for humans must surely be boundless. The diagnosis of human exceptionalism seems plausible in light of future-facing, progressive narratives that hold out the possibility of re-creating species-lauding humanity's godlike power to reshape the planet-while exhorting us not to dwell on species death. Death, especially mass death-especially human-caused mass death-does not advance the story.

\section{Climate Humanism on a Deathless Planet}

A certain grief-resistant strain of humanism, I would argue, similarly inflects some of our current discourse on climate change, especially (though not solely) climate reporting aimed more broadly at the public. At its worst, this discourse tip-toes to the edge of collapse porn, almost relishing the dark side of climate change- "like a voice from a nightmare" — with grave reminders of just how bad the situation is (Watts 2019). Yet the news is delivered with a certain air of bravado, as if to test the limits of what the reader can stand. A hallmark of climate humanism is its implicit disavowal of mourning for the Earth and its nonhuman inhabitants in favor of fear that can channel all our energies toward safeguarding human civilization. Some writers of this genre insist that the planet does not need humans to save it. After all, Earth is a 4.5-billion-year-old space rock that has withstood catastrophes far more dramatic than our current period of anthropogenic climate change, which appears against this backdrop as a mere geological blip, an "unimportant oscillation" (Latour 2018, p. 72). On this account, it is ourselves we must save. Earth itself will cycle on. We know this because we have grasped the long view of Earth-a planetary perspective-provided by sciences like geology or astrobiology. Thus, Neil deGrasse Tyson opines in a widely shared Earth Day tweet that environmentalists' perennial call to save the Earth is "odd." "Planet Earth," he insists, "survives massive asteroid strikes-it'll survive anything we throw at it. But Life on Earth will not." To whom or what does "Life" refer in this context? More to the point, what could it mean for "Earth" to continue without "Life"? What sort of Earth would that be?

It is Planet Earth that is predictably spoken of in these terms-a virtually timeless, deathless, and resilient entity with a long history of upheavals that preceded humans' arrival on the scene. Earth-as-planet recalls Bruno Latour's critical commentary on Earth as seen from space, or from the outside - a kind of spaceship Earth that Latour labels "nature-as-universe." Our planet surveyed as if from a rocket ship is distinct from nature-naturing or nature-as-process, a terrestrial vision of Earth that grasps its immediacy and vitality. "It is about the planetary vision that one can say, considering things 'from above,' that it has always varied and that it will outlast humans." The Terrestrial Earth,

4 Following Freud, grief that does not resolve in some way over time or that takes on an addictive quality is sometimes referred to as melancholia, to distinguish it from mourning.

5 Emerging rituals and commemorations like Species Remembrance Day and theatrical stagings of funerals for extinct species are examples of recent attempts to confront and process environmental grief. 
on the other hand, "does not allow this kind of detachment" (Latour 2018, p. 72). Earth as seen from the outside- one exoplanet among others, perhaps—is the Earth that we mistakenly believe we can somehow escape should it become inhospitable to us (even while it cycles on). Or perhaps we will simply reboot Earth with emerging technologies like geoengineering. Elite members of human civilization stand to benefit most from this detached off-planet perspective which renounces any notion of a shared world in favor of a headlong flight from climate threats. By contrast, the Terrestrial account foregrounds human interaction with and dependence upon nature, effectively decentering humans and returning agency to nature and the nonhuman realm.

In his remarkable book, The Unconstructable Earth, Frédéric Neyrat-who otherwise takes issue with many of Latour's theoretical contributions ${ }^{6}$ —offers a similar diagnosis. Earth as viewed from the extraplanetary position is part and parcel of a stance Neyrat calls "geo-constructivism," and an accompanying posture of anaturalism that refuses to recognize nature as a category at all. "It's as if the geo-constructivists view themselves as residing off-planet, outside the Earth," Neyrat writes, "without any kind of vital relation with the ecosphere, detached and separated as far away as possible from the Earth object to be reformatted" (Neyrat 2019, p. 5). The anaturalism of the geo-constructivist position results in a dubious kind of environmentalism "without nature," or "ignorant of it" (Neyrat 2019, p. 4). ${ }^{7}$ Nature is simply a nonbeing, "an inanimate and mathematizable material, upon which a human fashioning is applied that always tends toward extending the limits of the possible and transforming the impossible into the possible" (p. 5). Geo-constructivist technologies, ranging from synthetic biology to climate engineering, seek not merely to "conquer nature but to remake it" (p. 5). Earth is rendered "nonterrestrial," something to be steered or piloted; an entity to be remade-reconstructed—-through geoengineering, carbon capture, and the proposed de-extinction of lost species (p. 49). The survival of humanity-or, again, elite representatives thereof-becomes the overriding imperative of this post-environmental ecopragmatism. This emphasis on the long-term survival of an elite, globalized anthropos living on an exoplanetary space rock (if not Earth itself, then some reformatted version thereof, or another interchangeable planet altogether) suggests the affinities between geo-constructivism and what I call climate humanism.

While Neyrat does not put it in precisely these terms, the implication is clear: Planet Earth is rendered virtually unmournable, because it was never really alive or is deemed essentially deathless. Nature and nonhuman life are akin to the derealized bodies described by Judith Butler, entities that are "always already lost or, rather, never 'were,' and they must be killed, since they seem to live on, stubbornly, in this state of deadness" (qtd in Cunsolo 2017, p. 171). The Promethean idea that an extinct species—-something dead—could be technologically resuscitated, and the end-product deemed just as good (or better!) than the original, provides a disturbing case in point. That Earth itself could be remade, or simply exchanged for another habitable world, carries the same troubling suggestion. Earth stands ready to be reconstructed as Earth 2.0. "Death itself," Neyrat writes, "no longer has a place within this scientifico-discursive apparatus.... The death of nature will simply have been the necessary step toward the programming of its controlled resurrection" (Neyrat 2019, pp. 53-54). Earth might as well be Mars-or Mars a perfectly acceptable substitute for earth—as if Earth were somehow "lacking life" or "already dead" (p. 52).

Often, as both Neyrat and Latour suggest, the geo-constructivist impulse-like climate humanism-exhibits both a defensive and a faux-courageous quality, stemming from its refusal to recognize shared vulnerability with other lifeforms, or even, in some cases, our common predicament

6 Neyrat's critique particularly targets Latour's dalliance (if that is what it is) with ecomodernism, as seen in his essay "Love Your Monsters: Why We Must Care for Our technologies As We Do Our Children," published as a contribution to a volume edited by ecomodernism's founders, Ted Nordhaus and Michael Shellenberger.

7 On Neyrat's account, this erasure can be effected either through the distancing and objectifying move of Earth as an exoplanet in space or by positing radical entanglement and a generalized hyperconnectedness that sees humans as everywhere and always intermeshed with Earth-or some combination of the two. Neyrat rejects both in favor of an ecology of separation, as he terms it, that allows an unconstructed Earth to reclaim its alterity and singularity. 
with fellow humans. When Anthropocene commentators of the climate humanist variety pinpoint the human enterprise as that which is truly at stake, this insight is very clarifying. Let us be honest, they say, about what "we" really fear losing and how we might minimize the losses. As Butler argues, that which we do not grieve reveals a lot about us. "I am as much constituted by those I do grieve for as by those whose deaths I disavow" (qtd in Cunsolo 2017, p. 13). In an era of climate change and extinction, the category of ungrieved and ungrievable entities has expanded to include "the melting of ice caps, the permanent loss of biodiversity through human-induced extinction, and the changes in lands all over the world because of climatic shifts and variability" (Cunsolo 2017, p. 174). These deaths "often escape the literature around mourning, and our own conceptualizations of mournable bodies" (Willox 2012, p. 146).

As an example of climate humanism largely detached from mourning for life beyond the human project, consider the work of David Wallace-Wells. Wallace-Wells is perhaps best known as the author of an article that appeared in New York Magazine in 2017 called "The Uninhabitable Earth," and a subsequent book by the same title. His reporting has shocked and angered many readers, including some climate scientists, who found it unnecessarily hopeless. His widely quoted tagline is now familiar to many: climate change "is worse, much worse, than you think." In light of this assessment, we might expect to find in his work a meditation upon grief for the "Earth" we are making uninhabitable. Yet there is surprisingly little concern for, or even acknowledgment of, nature and the nonhuman world in Wallace-Wells' writing, or in his discussions elsewhere of what motivates his climate concerns.

Regarding his turn to climate change as a topic of research, Wallace-Wells reports that he happened upon the climate story by accident (Klein 2019b). ${ }^{8}$ He sensed there was a gap in climate reportage and that mainstream media sources were underplaying the alarm. His interest, he notes, was that of a "competitive journalist," not that of an environmentalist-a term he regularly dismisses (Wallace-Wells 2019; Swisher 2019). ${ }^{9}$ He calculated that by breaking such a story-filling the news gap-he could "punch up" to top tier journalism (Klein 2019b). (His brother, Benjamin, is a veteran journalist and staff writer for the highly regarded New Yorker magazine). On Wallace-Wells' reading, climate change had been badly communicated to the public as a slow-moving threat having largely to do with sea level rise. Hence, if you did not live directly on a coast, you could blithely assume you were immune from devastating impacts. Wallace-Wells describes himself as a lifelong urbanite, a New Yorker, who considered his city a "fortress," a place outside of nature that could never be infiltrated by its forces. He confesses that he came of age as "an end of history kid," a believer in progress who felt "in my core, that over time, things got better, people got richer." He came to realize that no one should assume they are safe from climate change "no matter how fully defended [they] are" (Klein 2019b). As someone who imagined himself insulated from nature, he was genuinely shocked to discover the many terrifying, cascading effects of climate change beyond sea level rise: new mosquito-borne diseases, a plunging GDP, geopolitical upheaval, crop failures, etc. In other words, when Wallace-Wells says that climate change is "worse, much worse, than you think," he means it is much worse than he thought. Uninhabitable Earth, it appears, is the product of his realization of his own vulnerability.

Yet, what is striking about Wallace-Wells' alleged awakening is how seldom it acknowledges (much less laments) harms and losses to the natural world. By his own admission, very little of the book deals with "'nature' per se" and "none" of it concerns animals (Wallace-Wells 2019, p. 39). "I tend to think when you're at the top of the food chain, it's okay to flaunt it" (Wallace-Wells 2019, p. 7). He discusses climate-induced devastation of insect populations, for example, in terms of consequences for the human food supply. When the topic of extinction is raised, he describes himself as "not invested in the fate of animals" (Klein 2019b). As with generations of environmental writers before

8 Wallace-Wells made these remarks in an interview on the Ezra Klein show on 24 March 2019. https://www.stitcher.com/ podcast/vox/the-ezra-klein-show/e/59194732.

9 Wallace-Wells makes similar comments about his motivations for reporting on climate in the interview on the Ezra Klein show, cited previously. 
him, Wallace-Wells understands fear and alarm to be powerful vehicles for change, and there is indeed considerable stoking of fear in his climate reporting. In interviews, he repeatedly assesses climate scenarios as "really, really bad" and "terrifying," predicting a future "hellscape" of a planet. "The facts are hysterical" (Wallace-Wells 2019, p. 32). But his expressions of fear are framed primarily as threats to human survival; solutions, insofar as he offers any, stake a claim to technologies of carbon removal and faith in progress as the antidote to fatalism. His awakening remains incomplete at best, in its refusal of vulnerability and its repudiation of grief for the natural world. He aspires to build an all-hands-on-deck movement among people like himself who do not identify with "environmentalism" or have never considered themselves lovers of nature. He calls for "lowering the price of admission" to joining the climate cause; that is, we should not expect all comers to have a stake in the same issues, or even to concern themselves with life beyond the human enterprise (Klein 2019b).

Young climate activists, like Varshini Prakash who became involved in climate activism at the age of 19 and now leads the youth climate movement called Sunrise, can be heard expressing similar sentiments. Prakash describes coming of age in an era of climate crisis, explaining that the youth movement birthed by such trauma aims at human self-preservation, not "saving the planet." "The planet," she observes, "is going to be here long after humanity is dead and gone" (Klein 2019a). Prakash-more so than Wallace-Wells—acknowledges that nonhuman species also suffer from climate change, yet the tendency is to rally around preserving civilization. She laments that the climate movement has been too tightly coupled with the environmental movement. "It feels like for the last 40 years it's been gated to the realm of environmentalism. Like it's about saving the environment or preserving the environment, not salvation for humankind more broadly and preserving our way of life" (Klein 2019a).

To be sure, there is value in sounding the alarm on climate change, particularly for those who, like Wallace-Wells, have remained oblivious to its kaleidoscope of impacts. ${ }^{10}$ There is also much to commend in the grassroots work of the Sunrise movement. The big tent approach sounds perfectly reasonable. Time is short, after all, and we cannot afford to scrutinize and quibble over the values that motivate action on climate change across a spectrum of personal and political commitments. But there is also a troubling strand of accommodationism to anthropocentric, instrumental values in these approaches to climate change, and in some cases, a disconcerting lack of identification with an Earth that retains a vital living presence. It is difficult to imagine authentic change emerging from movements that routinely foreground human civilization, and fail to mourn catastrophic losses to the living world beyond humans. Genuine, attentive mourning for losses beyond our own might work against "a deeply ingrained habit of seeing the natural world as an object, a thing somehow detached from our own lives" (Christie 2013, p. 71).

A far more extreme and rather chilling example of preoccupation with sheer survival, and pronounced resistance to solidarity, is offered by Douglas Rushkoff, a media theorist and novelist associated with the cyberpunk movement (a genre of science fiction typically oriented around a high-tech, dystopian future). Rushkoff's account appears in the handbook of the Extinction Rebellion movement, This is Not a Drill. By way of background, Extinction Rebellion (XR) is sometimes seen as part of a darker, brooding segment of the climate movement. ${ }^{11}$ Grief and mourning are built into its guiding principles and central to its activist philosophy. References abound to a "dying planet," "ecocide," and activism born of "ferocious love" for the land, and XR protests often stage funeral processions and enact rituals of grieving (Farrell et al. 2019). Gail Bradbrook, one of the founders of XR, speaks candidly about her use of psychedelic drugs to open herself to environmental grief and trauma, but also to her own "deeply felt sense of peace, oneness, and unity with the planet" (Bradbrook 2019).

10 Wallace-Wells at times compares his approach to that of Rachel Carson. It is worth noting, however, that the title, and much of the content, of Silent Spring (1962) addresses suffering and losses to nonhuman life as well as human.

11 For a similarly somber and highly creative take on environmental crisis, see The Dark Mountain Project founded by Paul Kingsnorth and other writers, artists and activists: https://dark-mountain.net/. 
In his essay for the XR handbook, Rushkoff brings these values to his analysis of elitist escapism and (literal) fortress-building (Rushkoff 2019). In fact, his essay is a perfect example of Latour's portrait of elites who loudly dismiss climate science while quietly hoarding the lifeboats. These people "have been so thoroughly convinced that there would be no future life for everyone," Latour writes, "that they have decided to get rid of all the burdens of solidarity as fast as possible" (Latour 2018, p. 18). Rushkoff describes receiving an almost unimaginably lucrative invitation to deliver a keynote address at a deluxe resort to an assembled group of investment bankers. Rather than being shown to the stage, he is ushered into a seminar room, where groups of wealthy bankers are brought directly to him-men (they are all men) from the "upper echelon of the hedge-fund world" (p. 58). They are not interested in hearing his prepared comments. Instead, they interrogate him about surviving the coming climate crisis. Some of these men, he learns, are already constructing luxurious underground bunkers. Others solicit his advice regarding which regions of the world might be spared the worst climate disruptions. How to protect their food supply. What to pay their security forces when money becomes worthless. One asks him pointblank: "How do I maintain authority over my security force after the event?" (p. 59). The event. Rushkoff realizes with horror that these men, like futurists Elon Musk and Ray Kurzweil, have invested in the future of technology-and thus, the future, generally, as they understand it-with an eye to one thing only: their own escape. In seeking escape, he writes, they were plotting to transcend "all that is human: the body, interdependence, compassion, vulnerability, and complexity" (p. 60). Needless to say, nonhuman beings do not enter into their plans at all-except, possibly, as food.

I am not suggesting that Wallace-Wells (or the Sunrise movement) partakes of the pathology of Rushkoff's hedge fund preppers. There are varying degrees of human-centeredness, fortification, and resistance to vulnerability and solidarity. But even relatively benign strains of climate humanism exhibit a striking dearth of feeling for a living Earth—distinct from a deathless planet—and a problematic emphasis on protecting what Prakash often calls "our way of life." While milder forms of climate humanism invoke human civilization as the primary object of preservation, the builders of gilded fortresses constrict the circle ever more narrowly, to include only elite individuals like themselves who believe they have the means to escape.

With these examples of the spectrum of resistance to grief and mourning in mind, I want to turn for the remainder of this essay to a more reflective and sober form of Anthropocene storytelling and the fragile but potent forms of hope made possible through the work of grief. Among the tales of climate mourning and protest that have recently made headline news, few can compete with the story of a little Icelandic glacier and its untimely demise. It is to this remarkable story that I turn next.

\section{Grief for a Living World: The Death of a Glacier}

Scholars who study environmental grief and mourning argue that we can expand our conceptions of what counts as mournable entities by attending to, reframing, and even practicing in our own lives, the work of mourning. "One possible avenue for reconstituting non-human bodies as grievable within the climate change arena is through the incorporation of the work of mourning in research, practice, public discourse, and action ... extend[ing] the concept of a mournable body beyond the human" (Cunsolo 2017, p. 173). The story of Okjökull glacier, or "OK" for short, provides a good example of what this work might look like among activists, scholars, and political leaders. The wide circulation of the story of OK glacier's demise owes much to the brilliant podcasting team of Cymene Howe and Dominic Boyer of Rice University, both of whom work at the intersection of anthropology and the energy humanities. ${ }^{12}$ A funeral rite for the vanished glacier was held in August 2019, and included a solemn hike up OK mountain where the glacier had once lived. Howe and Boyer, accompanied by a group of mourners, ascended the mountain. The mourners included Howe and Boyer's young daughter, as

12 Howe and Boyer host the podcast series "Cultures of Energy." 
well as other children; also present were the prime minister of Iceland, various scholars and artists, and a glaciologist who presented an official death certificate. The glaciologist spoke privately to Howe about the strangeness of pronouncing the glacier's death when no previous declaration of its birth, no christening, had ever occurred (Howe and Boyer 2019). ${ }^{13}$ "Excessive heat" was listed as the cause of death, with humans as the implied proximate cause: "Nothing was done to save it" (Johnson 2019). Interestingly, in a documentary about Okjökull, created by Howe and Boyer with Icelandic filmmaker Ragnar Hansson, the events surrounding the glacier's death are narrated in the personified (and thickly accented) voice of OK mountain. While giving a human voice to inanimate features of nature might strike some as problematically anthropomorphic, the film creates a compelling sense of the mountain as a living entity whose once-animate glacier is now a casualty of human indifference.

With or without christening rituals that declare glaciers officially alive, the perception of glaciers as living, even divine, entities capable of sustaining and destroying life is common across many cultures. "The glaciers' movements and sounds caused them to be perceived as animate forces worthy of respect and veneration by those living nearby," writes Elizabeth Allison in an essay that explores how climate change is reconfiguring the spiritual dimensions of glaciers (Allison 2015, p. 496). Finely honed rituals and rules of engagement with glaciers are observed in many such cultures, regarding, for example, when one may speak in the glacier's presence, how glacial water is to be collected, and how pilgrimages should be conducted. Among cultures that traditionally associate their deities with mountain glaciers, the melting of a glacier might be interpreted as punishment for moral transgressions. An overabundance of tourists traversing the mountain, or a lack of piety, awe, or reverence might be seen to trigger a glacier's decline (Allison 2015). Even glaciologists who otherwise insist on the abiotic nature of glaciers, speak and write in terms suggestive of animacy. Scientists describe glaciers as moving and growing; they are spoken of as repositories of memory, providing a record of past ages and environmental conditions, much like tree rings. "They also 'crawl' and have 'toes'; when they break off at the ablation edge, they are said to have calved," like an animal giving birth (Johnson 2019).

A glacier that no longer crawls or calves, that no longer records memories, is a dead glacier Only something deemed vital and living can be mourned as dead, and rituals of mourning, properly done, may effect a change in the living. Meaningful change is what Howe and Boyer, and the other mourners at Okjökull, hoped to achieve. A commemorative plaque created to mark the glacier's death sends a message to the future: "We know what is happening and what needs to be done. Only you know if we did it." During the ceremony surrounding the placement of this plaque, children were asked to come to the front of the crowd. Howe addressed them, saying "We need to understand our relationship to the world in ways we haven't had to in the past. We need to be able to imagine a new future" (Johnson 2019).

In The Secret Life of Glaciers (Jackson 2019), M Jackson relates the numerous stories she collected among Icelanders who perceive their glaciers to be sentient, living beings. Jackson's storytelling resonates with additional details of the funeral rite and pilgrimage to mark the death of Okjökull. These details, as told by Howe, have an intriguing mythic quality. Indeed, OK's story suggests a useful framing for thinking about hope, grief, and the possibility of moving forward into the future, while maintaining an intimate connection to the past. As noted previously, the ceremony for OK entailed a long walk up the mountain, culminating in the installation of the commemorative plaque. The last $100 \mathrm{~m}$ of the procession took place in silence, in accordance with Icelandic tradition. Tradition also dictates that climbers may make three wishes as they silently approach the summit, and that they are not to look backward as they ascend. Climbers who obey these rules are said to have their wishes fulfilled. OK's rocky terrain made the hike physically challenging, and as Howe explains, she was not

13 These and other details of the ceremony are described by Howe in a segment of the "Cultures of Energy" podcast recorded soon after the Icelandic ceremony. 
certain from one moment to the next whether her daughter had been able to keep up and was still somewhere close behind her. She wanted desperately to turn around, but also wished to respect the custom of forward-facing silence. On Howe's own interpretation of the ritual, ascending the mountain became a "metaphor for moving forward in the climatological apocalypse." "We have to keep moving forward," she says, "with whatever kinds of solutions we can come up with." Yet the injunction to keep going was "frustrating" as she became increasingly worried about her daughter's progress, somewhere behind her. Finally, still facing forward, she tentatively extended her hand backward, not knowing who was behind her or how they might react. A second later, she says, she felt her daughter's small hand grasp her own. "I started crying" (Howe and Boyer 2019). ${ }^{14}$

Readers of mythology may have a sense of déjà vu upon hearing this tale. I was immediately reminded of the legend of Orpheus and Eurydice as told by the third century BCE Greek poet Apollonius. Orpheus was an unparalleled musician who protected the Argonauts from the bewitching song of the Sirens. So enchanting was the music of his lyre that it saved the sailors from the Siren's deadly voices. According to other details of Orpheus's life, his young wife Eurydice is fatally struck by a viper shortly after they are wed. Inconsolable, Orpheus leverages his musical reputation to bargain for the return of his bride. He is allowed to enter the world of the dead, where he encounters a veritable who's-who of the underworld, all of them enchanted by his lyre. "The dog Cerberus relaxed his guard" and Tantalus "forgot his thirst" (Hamilton 1942, p. 140). Above all, Pluto, the ruler of Hades, was moved to tears. Orpheus's wish to retrieve his wife is swiftly granted and Eurydice summoned-but on one condition: Orpheus must not look back at her until the two have passed the gates of hell. As with Howe's narration of the mountain pilgrimage, Orpheus is desperate to sneak just "one glance to make sure" that Eurydice is still behind him (Hamilton 1942, p. 141). He resists, and gradually the darkness gives way to grey light, and then to sunshine. Certain that they have crossed the threshold, Orpheus steps into the light. He turns to look at Eurydice, but it is too soon-she is still in shadow. He reaches for her, but the darkness quickly reclaims her. The gods will not grant Orpheus another trip to the underworld.

It seems that there is no comfort whatsoever in this story of crisis and shattered hope, of grief compounded by a second wave of irrevocable loss. Other myths similarly warn us of the dangers of looking over our shoulder, toward the past. In the Old Testament, Lot's wife famously defies the directive not to look back and is transformed into a pillar of salt, the very symbol of paralysis. Popular readings of these stories enshrine a progressive, almost evolutionary edict to advance linearly, to evade death and its grave reminders, through sheer forward motion-or at least the appearance thereof. The prey animal, pausing to glance backward, is swiftly overtaken by the predator. But I wonder if we might be wrong to read these tales as simple injunctions against looking back-as if doing so constitutes a loss of faith, while forward motion is synonymous with hopeful action. We might complicate these readings of a forward-facing imperative and future orientation by reflecting more deeply on the nature of grief and hope. Other voices-journalists, activists, feminists, artists—can tell us a different, more humane, story about these emotional states, and what it means to advance. For additional insights into the nature of crisis, and the power of mourning and hope in their complex entanglements with the past, present, and future, I turn to journalist Dahr Jamail, and writer and activist Rebecca Solnit.

\section{The Gift of Grief in the Anthropocene}

It is difficult not to compare Wallace-Wells' climate reporting with that of Dahr Jamail, author of The End of Ice. Their books on climate change both appeared in 2019, and the two works are often reviewed and discussed in tandem. Jamail's book opens with a dedication to "future generations of

14 Howe's telling of the story is, on the whole, much more lighthearted and jocular than my narration here. Nevertheless, I found the story very moving. 
all species," and indeed the plight of nature and nonhumans figures prominently in his grief-soaked writing. Jamail frequently draws on the metaphor of "witnessing," likening climate mourning to the inevitable loss of a terminally ill friend. A concluding chapter, simply called "Presence," offers a more extended reflection on what it means to love, and bear witness to, an Earth that "may well be dying" (Jamail 2019, p. 216). Jamail embraces what he calls the gifts of crisis which for him include being more present, even feeling more alive, than ever before in the midst of grief. These gifts "are the conditions that make possible widespread shifts in political identity, purpose, and consciousness" (Jamail 2019, p. 216). Being present with Earth is a way of remaining connected to sorrow. Accepting Earth's probable decline "opens into a more intimate and heartfelt union with life itself" (Jamail 2019, p. 219). He describes this experience as "falling in love with the Earth in a way I never thought possible." Witnessing allows him to rededicate himself to his work each day, even if it means "my heart breaks, over and over again" with each successive wave of loss (p. 219).

Drawing on the contemplative traditions of ancient monks, Douglas Christie describes the attentive practice of dwelling in grief and tears as "penthos or katanyxis," Greek terms suggestive of a "profound piercing of the heart" and a paradoxically joyful form of sorrow and penitence (Christie 2013, p. 74). Allowing oneself to grieve, and especially giving oneself over to honest, heartfelt weeping, was considered essential to ascetic practice and spiritual renewal. Seeing the world through tears, with a wounded heart, Christie argues, is a fitting contemplative ecological practice in today's world, one that fosters a sense of being alive and awake to the beauty and fragility of nature. "Tears for lost places, for a whole lost world of possibilities. Also, tears born of gratitude for what has been, for what might yet be retrieved and restored. Tears as a source of renewal. Tears as gift." (Christie 2013, p. 74). The ancient practice of memento mori, a sustained reflection on mortality, finitude, vulnerability, and death, was thought to reorient the practitioner toward meaning, purpose, and one's own limits, creating a sense of urgency, or what the monastic tradition calls compunction: "learning to live continuously against a horizon of ultimacy"; to be carried "across a threshold on the far side of which lay a qualitatively different existence" (Christie 2013, p. 76).

The End of Ice is a memento mori for nature, an extended meditation on heartbreak and the sense of compunction that brokenness makes possible. Jamail is no stranger to trauma, having spent several months as one of very few unembedded journalists in occupied Iraq. But long before that phase of his career, Jamail had developed a deep attachment to mountains. His writing expresses a climbers' love for landscapes whose desecration he feels compelled to document. Reflecting on the similarities between his work in Iraq and his turn to writing about climate change, Jamail describes the shattering of hope that made way for a generative form of grief. This grief, in turn, gives birth to a new "hope-free" form of hope. "I had hoped my work in Iraq would contribute to ending the U.S. occupation ... I had hoped, too, that writing climate dispatches and bludgeoning people with scientific reports about increasingly dire predictions of the future would wake them up to the planetary crisis" (Jamail 2019, p. 217). Surrendering hope, he says, was difficult, but he came to realize that hope, as he had previously experienced it, was an impediment. He turns to the Canadian storyteller Stephen Jenkinson, a leader in palliative care counseling who grasps the imperative "to burn through the false choice of being hopeful and hopeless." Grief, Jenkinson concludes, "is required to proceed" (qtd. in Jamail 2019, p. 218).

Jamail's initial tactic of "bludgeoning" readers with grave reports to force an awakening is reminiscent of Wallace-Wells' approach. But to dwell in grief and bear witness to devastating losses beyond the threats to human civilization, as Jamail does, is to renounce a defensive stance. An expansive sense of grief and love for Earth in its living — and possibly dying—state can catalyze the "extraordinary alchemy" that turns grief and despair into "profound activism"- a kind of forward motion that does not lose sight of the sorrow that drives it (p. 217). Jamail's language of presence, of being-with Earth in a period of decline, is echoed by other scholars in the environmental humanities who invoke metaphors of palliative care, and hospice- of "de-colonizing" extinction rather than pressing forward with controlling, heroic measures to save the last members of a species at all costs (Parreñas 2018). Thom van Dooren worries about the forms of "violent-care" entailed in all-out efforts to pull species 
back from the brink of extinction, at great pain and sacrifice to the individual animals themselves (Van Dooren [2014] 2016). He and Deborah Bird Rose urge us to "keep faith with the dead" as an expression of resistance to the techo-allure of de-extinction strategies. Those, like Stewart Brand, who would steer us away from mourning are engaged in "an ostentatious display of bad faith toward both the living and the dead." Dismissals of mourning

buy into what the environmental philosopher Daniel Innerarity has called "false motion." Here, the bright promise of new technologies, of doing something, undermines the genuine reflection needed to get somewhere better—not just different (Van Dooren and Rose 2017, p. 376).

Elsewhere, Rose describes the delicate and critical weave-work that is accomplished by death narratives, as in stories traditionally told by Indigenous cultures that situate death in place and time, memory and wisdom. Here, death is turned back toward life, through acknowledging connectivity between the deceased and the living, the past and the future. Turning away from death, erasing rather than honoring it, amplifies death and twists it into grotesque forms. "Death binds living beings into an ecological web," she writes, but ecological catastrophe — man-made mass death—brings "cascading ruination of both past and future life and death" (Rose 2011, pp. 91-92). The hallmark of a death-denying culture is that it treats the resulting wreckage as merely the acceptable "by-product or collateral damage" of progress toward a non-existent "better world"- -a future that cannot come into being because it has been severed from its own past (p. 89).

Environmental philosopher Ben Minteer similarly questions the fixation of de-extinction enthusiasts with a "cheerier story, a more uplifting narrative driven by sunny acts of biological creation and ecological recovery" (Minteer 2019, p. 109). Our attraction to technologies that advance the upbeat storyline is an evasion of the hard lessons of extinction, lessons that can only be absorbed by sitting with the mistakes of the past, and with the deeper moral problems of which extinction is a symptom. Meditation on extinction is a powerful reminder of "our fallibility and our finitude" (Minteer 2014, p. 261). We might say that de-extinction denies the irreversibility, the irrevocable nature of species death, rendering these creatures not fully alive- and therefore ungrievable-even while they live. It mistakes mourning for inaction, or failure.

Dahr Jamail sometimes describes the proper response to climate change as learning how to fail. By this he means, in part, learning to live in accordance with what is rather than what might be in the future-doing your best, even knowing that it might all go down in flames. Attunement to what is necessarily entails an admission that you do not know what might happen. It is within this space of uncertainty that grief and hope co-exist. We act without knowing whether what we do actually does anything. But nor can we be certain that what we do does nothing. "I surrendered my attachment to any results that might stem from my work" (Jamail 2019, p. 219).

\section{Falling Together}

Jamail's (somewhat Buddhist-sounding) reflections on loss, grief, and hope share certain affinities with Rebecca Solnit's discussion of what she calls "hope in the dark," the title of a book originally published in 2004, and reissued with updated material after the election of Donald Trump (Solnit 2016). Among the many topics her work has canvassed over the years, Solnit has a particular interest in the meanings to be found in disasters like Hurricane Katrina or the Fukushima nuclear accident. Her work does not radiate the searing grief of Dahr Jamail—in fact, some might deem it not nearly dark enough for our times-but the parallels are instructive, and they suggest how we might orient ourselves toward the future without forgetting where we have been. She points us to the many astonishing and unanticipated events that have unfolded in recent years: the Arab Spring, Occupy Wall Street, Black Lives Matter, and more recently, the arrival of Brexit and Donald Trump. Echoing Jamail, she describes the "proximity of death in shared calamity" that nevertheless creates a sense of purpose, joy, and vitality (Solnit 2020a). Solnit recognizes that "there is meaning as well as pain in sadness, mourning and grief, the emotions born of empathy and solidarity" (Solnit 2020a). Recently, 
in the midst of the Covid-19 pandemic, Solnit was a reassuring voice to many, as she turned to reading fairytales in nightly online sessions that attracted enormous (virtual) crowds of listeners completely rattled by an indefinite lockdown. Fairytales-a genre of never-ending stories— “felt like the right kind of narrative" in a sustained period of "not knowing" (Solnit 2020b).

While some of the developments Solnit reflects upon are shocking in ways that appear decidedly negative, they nevertheless underscore her point about the fundamental unpredictability, the sheer nonlinearity, of life and what we call history. Uncertainty is what makes hope possible. Novel forms of protest and resistance have arisen around the world, and with them counter-resistances and counter-protests, in ways no one anticipated. Hope, Solnit writes, "locates itself in the premise that we don't know what will happen, and in the spaciousness of uncertainty is the room to act" (Solnit 2016, p. xiv).

In particular, Solnit is fascinated by the way people actually behave during crises, and she is particularly drawn to a certain mysterious emotion, a peculiar joy, that often lights up the faces of those who experience disaster. The stories we have been told about so-called human nature lead us to expect that in the midst of crisis, humans devolve into crass social Darwinists and savage Hobbesians. But disasters can often rivet people to the present moment in the best possible way. Solnit, like Jamail, sees crisis as giving rise to a "super-saturated immediacy" and a deep sense of connection. The "violent gift" of such experiences, Solnit writes, "is that you feel more alive." So do others around you-there is a shared experience, not of falling apart, but what Solnit calls "falling together" (Tippett 2016). A rejection of this joyful but grieving solidarity—an outright refusal of falling together-characterizes the investment bankers Rushkoff describes, and the elites Latour depicts as abandoning a shared world. As Rushkoff's account suggests, some of us do devolve into barbaric Hobbesians defending only our immediate territory and interests-or hoarders of face masks in the midst of a pandemic. And often it appears that the more secure and insulated we are-in plainest terms, the wealthier we are- the greater the resistance to acknowledging vulnerability. As Solnit observes, "one of the primary uses of wealth has always been to buy your way out of the common fate" (Solnit 2020a). The idea that we and other humans, and that humans and nonhuman life share a common fate is understood only as an infringement on freedom. Thus, as with Rushkoff's investment bankers, technology becomes a vehicle not of collective flourishing but of individual, material survival. For these men, there is simply nothing to grieve.

An absence of grief is, oddly enough, symptomatic of an underlying certainty, whether it is the certainty of optimism or that of despair-certainty that the future will simply be a continuation of the status quo or will decline from it. Both optimism and despair can serve as grounds for doing nothing, or simply doing more of the same. Hope, therefore, is distinct from optimism. Solnit explains that the title of her work "hope in the dark" is an effort to reclaim darkness from its negative, and especially racist, associations. Disaster rivets us to the present moment, but the future is veiled in darkness. This is the darkness not of the tomb, but of the womb-a place of mystery where something novel may spring to life. Significantly, she argues that hope has been misunderstood as singularly oriented toward the future. In truth, hope is often grounded in the past, for it is a function of memory. For this insight, she credits the work of theologian Walter Brueggemann, who understood that the past, and our memory of it, confirms that we did not know what was going to happen, before it happened. "Memory produces hope in the same way that amnesia produces despair," Brueggeman writes (Solnit 2016, p. xix). It may sound obvious or even trite to point out that we do not know what will happen before it happens. And yet the way we routinely narrate history-how we tell stories generally-makes it appear as if events were inevitable, as if they unspooled, unerringly, according to some inner logic. "We pretend that life like art has plots and we know how the story ends, whether it's an election or a cultural shift or the outcome of any major event," Solnit writes, "and we often err not on the side of caution but on the side of conventionality: the future will look like the present"(Solnit 2020b). But in its complexity and its unforeseen shifts, history is more like weather than like checkers (Solnit 2016, p. 61). The forward-looking energy that we rightly associate with hope springs in part, then, from our 
clear-eyed recollection of having been surprised by events in the past. By grounding ourselves in the past, recalling the unexpected twists and turns history has previously taken, we can better navigate the dark of the future.

Solnit's commentary on shadow and light, history and the future, may suggest a different reading of common narratives, both old and new, through which we seek to understand the present moment. On this account, the darkness of the future-not a sinister gloom but the hiddenness of generative uncertainty and possibility - contrasts with the daylight of the present and the past. It is this daylight, she insists, that is carried forward into the dark of the future. It is this light that illuminates the faces of people falling together in the joy-bearing grief-the penthos—of crisis. Our anchoring in the past-its surprises as well as its mistakes-illuminates an uncertain path, and creates a sense of purpose in the present moment. Maybe, then, the Orphean myth gets it wrong. To advance, to move forward, is not to transition in linear fashion from darkness to light. Perhaps the past is not a trap but a repository of memory and insight that can provide stable footing in times of uncertainty and loss. Danger lies not in looking back, but in believing that release from a shadowy past can and should be granted through perpetual, but often "false," forms of motion. The story of the funerary procession on Okjökull, on the other hand, seems to get something fundamentally right, despite the admonition against looking back—a message, perhaps, about being present while confronting the future as the difficult work of grief. A mother's story of moving forward, her hand reaching tentatively behind her, seeking connection with the person in her wake-a person who may or may not be her own child, who may or may not accept the extended hand-this story seems an improvement on the myths we have inherited. The narrative's commingling of grief, hope, solemn action, and sudden unexpected joy is more powerful than "Age of Human" stories of techno-optimism and their disavowal of death, memory, and solidarity. And just as hope, tethered to the past, makes forward motion imaginable, so the young daughter who grasps her mother's outstretched hand embodies what the future may yet become, in all its veiled possibility.

Funding: This research received no external funding.

Conflicts of Interest: The author declares no conflict of interest.

\section{References}

Ackerman, Diane. 2015. The Human Age: The World Shaped by Us. New York: Norton and Company.

Allison, Elizabeth A. 2015. The Spiritual Significance of Glaciers in an Age of Climate Change. Wiley Interdisciplinary Reviews: Climate Change 6: 493-508. [CrossRef]

Bradbrook, Gail. 2019. How Psychedelics Helped to Shape Extinction Rebellion. Insight. March 25. Available online: https://www.whatisemerging.com/opinions/psychedelics-and-social-change (accessed on 5 May 2020).

Brand, Stewart. 2013. The Dawn of De-Extinction: Are You Ready? TED: Ideas Worth Spreading. Available online: https://www.ted.com/talks/stewart_brand_the_dawn_of_de_extinction_are_you_ready/transcript? language =en (accessed on 5 May 2020).

Christie, Douglas E. 2013. The Blue Sapphire of the Mind: Notes for a Contemplative Ecology. New York: Oxford University Press.

Cunsolo, Ashlee. 2017. Climate Change as the Work of Mourning. In Mourning Nature: Hope at the Heart of Ecological Loss and Grief. Edited by Ashlee Cunsolo and Karen Landman. Montreal and Kingston: McGill-Queens University Press.

Farrell, Clare, Allison Green, Sam Knights, and William Skeaping. 2019. This is Not a Drill. New York: Penguin. Hamilton, Edith. 1942. Mythology. Boston: Little, Brown, and Company.

Hance, Jeremy. 2016. Why Don't We Grieve for Extinct Species? The Guardian. November 19. Available online: https://www.theguardian.com/environment/radical-conservation/2016/nov/19/extinctionremembrance-day-theatre-ritual-thylacine-grief (accessed on 5 May 2020).

Heise, Ursula. 2016. Imagining Extinction: The Cultural Meanings of Endangered Species. Chicago: University of Chicago Press. 
Howe, Cymene, and Dominic Boyer. 2019. Cultures of Energy Podcast. Episode 191. August 22. Available online: http://culturesofenergy.com/191-amanda-boetzkes/ (accessed on 10 June 2020).

Jackson, M. 2019. The Secret Life of Glaciers. Brattleboro: Green Writers Press.

Jamail, Dahr. 2019. The End of Ice: Bearing Witness and Finding Meaning in the Path of Climate Disruption. New York: The New Press.

Jenkins, Willis. n.d. Loving Swarms: Religious Ethics Amidst Mass Extinctions. Draft paper.

Johnson, Lacy M. 2019. How to Mourn a Glacier. New Yorker Magazine. October 20. Available online: https://www.newyorker.com/news/dispatch/how-to-mourn-a-glacier (accessed on 5 May 2020).

Klein, Ezra. 2019a. Generation Climate Change. Ezra Sits Down with Varshini Prakash of Sunrise Movement. The Ezra Klein Show. July 31. Available online: https://www.vox.com/ezra-klein-show-podcast/2019/7/31/ 20732041/varshini-prakash-sunrise-movement-green-new-deal (accessed on 5 May 2020).

Klein, Ezra. 2019b. Life After Climate Change with David Wallace-Wells. The Ezra Klein Show. March 4. Available online: https://www.stitcher.com/podcast/vox/the-ezra-klein-show/e/59194732 (accessed on 5 May 2020).

Latour, Bruno. 2018. Down to Earth: Politics in the New Climatic Regime. Translated by Catherine Porter. Cambridge: Polity.

Menning, Nancy. 2017. Environmental Mourning and the Religious Imagination. In Mourning Nature: Hope at the Heart of Ecological Loss. Edited by Ashlee Cunsolo and Karen Landman. Montreal and Kingston: McGill-Queens University Press.

Minteer, Ben. 2014. Is It Right to Reverse Extinction? Nature 509: 261. [CrossRef] [PubMed]

Minteer, Ben. 2019. The Fall of the Wild: Extinction, De-Extinction, and the Ethics of Conservation. New York: Columbia University Press.

Neyrat, Frédéric. 2019. The Unconstructable Earth: An Ecology of Separation. New York: Fordham University Press.

Parreñas, Juno Salazar. 2018. Decolonizing Extinction: The Work of Care in Orangutan Rehabilitation. Durham: Duke University Press.

Read, Rupert. 2019. Iceland is Mourning a Dead Glacier: How Grieving over Ecological Destruction Can Help Us Face Climate Change. The Conversation. Available online: https://theconversation.com/iceland-is-mourninga-dead-glacier-how-grieving-over-ecological-destruction-can-help-us-face-the-climate-crisis-122071 (accessed on 5 May 2020).

Rich, Nathaniel. 2014. The Mammoth Cometh. New York Times Magazine. February 27. Available online: https://www.nytimes.com/2014/03/02/magazine/the-mammoth-cometh.html (accessed on 5 May 2020).

Rose, Deborah Bird. 2011. Wild Dog Dreaming: Love and Extinction. Charlottesville: University of Virginia Press.

Rushkoff, Douglas. 2019. Survival of the Richest. In This Is Not a Drill: An Extinction Rebellion Handbook. Edited by Clare Farrell, Alison Green, Sam Knights and William Skeaping. New York: Penguin.

Sideris, Lisa H. 2016. Anthropocene Convergences: A Report from the Field. In Whose Anthropocene? Revisiting Dipesh Chakrabarty's 'Four Theses'. Edited by Robert Emmett and Thomas Lekan. RCC Perspectives: Transformations in Environment and Society 2: 89-96.

Skrimshire, Stefan. 2019. Extinction Rebellion and the New Visibility of Religious Protest. Open Democracy. May 12. Available online: https://www.opendemocracy.net/en/transformation/extinction-rebellion-and-newvisibility-religious-protest/ (accessed on 5 May 2020).

Solnit, Rebecca. 2016. Hope in the Dark: Untold Histories, Wild Possibilities. Chicago: Haymarket Books.

Solnit, Rebecca. 2020a. 'The Impossible Has Already Happened': What Coronavirus Can Teach Us About Hope. The Guardian. April 7. Available online: https://www.theguardian.com/world/2020/apr/07/what-coronaviruscan-teach-us-about-hope-rebecca-solnit (accessed on 5 May 2020).

Solnit, Rebecca. 2020b. On Letting Go of Certainty in a Story that Never Ends. The Literary Hub. April 23. Available online: https://lithub.com/rebecca-solnit-life-inside-this-strange-new-fairytale-doesnt-have-to-be-lonely/ (accessed on 5 May 2020).

Swisher, Kara. 2019. 'The Uninhabitable Earth' author David Wallace-Wells says Tech is Failing on Climate Change. Recode Podcasts. April 10. Available online: https://www.vox.com/podcasts/2019/4/10/18303533/davidwallace-wells-global-warming-climate-change-uninhabitable-earth-book-kara-swisher-podcast (accessed on 5 May 2020).

Tippett, Krista. 2016. Rebecca Solnit: Falling Together. On Being, March 26.

Van Dooren, Thom. 2016. Flight Ways: Life and Loss at the Edge of Extinction. New York: Columbia University Press. First published 2014. 
Van Dooren, Thom, and Deborah Bird Rose. 2017. Keeping Faith with the Dead: Mourning and De-Extinction. Zoologist 38: 375-78. [CrossRef]

Wallace-Wells, David. 2019. The Uninhabitable Earth. New York: Tim Duggan Books.

Watts, Jonathan. 2019. David Wallace-Wells on Climate: 'People Should be Scared-I'm Scared.'. The Guardian, February 3.

Willox, Ashlee Cunsolo. 2012. Climate Change as the Work of Mourning. Ethics and the Environment 17: 137-64. [CrossRef]

(C) 2020 by the author. Licensee MDPI, Basel, Switzerland. This article is an open access article distributed under the terms and conditions of the Creative Commons Attribution (CC BY) license (http://creativecommons.org/licenses/by/4.0/). 
Article

\title{
Sacred Places and Planetary Stresses: Sanctuaries as Laboratories of Religious and Ecological Change
}

\author{
Willis Jenkins \\ Religious Studies, University of Virginia, Charlottesville, VA 22902, USA; willis.jenkins@virginia.edu
}

Received: 10 March 2020; Accepted: 21 April 2020; Published: 27 April 2020

\begin{abstract}
How are global relations and planetary flows experienced, interpreted, and managed from places set aside from everyday use, as "sacred" in that sense? Sanctuary Lab, a transdisciplinary initiative at UVA, investigates how religious processes interact with planetary stresses. Provisionally adopting a keyword in religious studies, the sacred, opens a post-disciplinary angle of inquiry into Anthropocene processes of cultural and environmental change. Focusing on dynamics of change in places regarded as sanctuaries affords unique perspective on how rapid planetary changes interact with particular inherited streams of normativity and imagination. This essay integrates field note illustrations from Yellowstone and Bhutan with critical reflection on the lab's approach in order to share initial hypotheses, collaborative research practices, and potential significance. It suggests that sacralization is part of the process through which cultures make sense of rapid changes; that nonhumans participate in sacralization; that sanctuaries offer unique laboratories of coupled change; and that arts-based exercises can help drive critical reflection on experience and method.
\end{abstract}

Keywords: sacred; Yellowstone; Bhutan; Jordan River; climate change; religion; Anthropocene; multispecies

How are Anthropocene relations bearing on religion, and how are religious processes shaping Anthropocene futures? Some form of that question guides recent work from scholars interpreting religious dimensions of rapid ecological and cultural changes (Veldman et al. 2014; Deane-Drummond et al. 2017; Latour 2017; Sideris 2017; Jenkins et al. 2018; Haberman n.d.). Among the challenges for this growing area of research, scholars often note that its lead question needs methodological experiment, interdisciplinary collaboration, and contextual specificity. This essay aims to advance ideas for researching contextual interactions of planetary stress with inherited formations of religion by thinking with Sanctuary Lab, a transdisciplinary initiative at the University of Virginia studying how shifting global relations and planetary stresses are experienced, interpreted, and managed from places set aside as special-as sacred, in that sense.

"As the flows of energy and matter around the world are altered, and a new geological epoch emerges, what will become of the sacred?" So asks Szerszynski (2017a, p. 235), who suggests that the Anthropocene may be driving cultural shifts analogous in scope to those of the Axial Age. The wager of Sanctuary Lab is that by asking how shifting flows of energy and matter interact with particular sacred places, researchers may create lines of inquiry into what is becoming of the traditions and societies that interpret those places as sacred. It therefore investigates political and environmental consequences of sacralization processes, their vulnerability to rapid planetary shifts, and the implications of their interaction with those shifts.

Sanctuaries offer a unique vantage into ecological and cultural change insofar as they are places set aside from normal pressures and uses. They are valuable for inquiry into change precisely because they are often imagined to offer refuge from change. Pressures on them, we hypothesize, must exert pressure on the traditions and processes by which they have been made special. I co-direct the lab with Kurtis Schaeffer (Tibetan Buddhism) and Martien Halvorson-Taylor (Hebrew Scriptures), which also includes faculty in Environmental Sciences, Music, Chemistry, Astronomy, Anthropology, and 
Law. Local experts join the team for each site. We focused on Yellowstone in Winter 2018; Bhutan in Winter 2019; delayed a 2020 focus on the Jordan River Basin due to the COVID-19 pandemic; and have further sites in early planning stages. The pause in the lab's sequence due to the pandemic presents an opportunity to share these mid-course lines of reflection on the experiment.

Szerszynski's creativity in answering his lead question has been stimulating. In recent years he has composed narrative performance pieces that imagine futures of religious life reshaped by planetary forces (Szerszynski 2017b). For example, his "Martian Book of the Dead," describes the script for an AI program used on a terraformed Mars to prepare dying Buddhists to merge with the becoming of their adopted planet. It is meant to be performed on stage with another, written as if by an historian of religion toward the end of the 22nd century on Earth. Szerszynski's integration of religious and geological scales, as well as his performative mode, seems apt. Sanctuary Lab asks: can we make from our scholarly tools and knowledges real-time ways to investigate, archive, and dramatize the shifting interactions of rapid planetary change with particular inherited streams of normativity and imagination? What possible future landscapes of religion emerge as we do?

Because the lab employs multiple methods and organizes collaborative inquiry along the experience of an itinerary, this essay integrates narrative vignettes with conceptual reflection. Working from sketched illustrations of field notes, it develops speculative lines of inquiry into contextual interactions of planetary stress with inherited formations of religion. The unconventional style of academic writing reflects the experiment. In each section I convey how a certain angle of inquiry emerged from the lab's participants and processes and sharpen it in connection to related scholarship. I also develop tension between sections to stimulate critical reflection on the lab's terms and suggestions. My claims here are as provisional as sketched illustration and speculative inquiry suggest. I could not offer interpretation adequate to any of these sites nor to the histories of scholarship attending each. My purpose is to share hypotheses, comparative questions, and collaborative research practices that have emerged from the lab as its researchers work together to investigate how cultural processes are interacting global flows and planetary stresses in particular places.

\section{Thresholds of Yellowstone}

The ecologist's voice broke as he described climate-driven scenarios of ecosystem shifts. Mike Tercek has worked at Yellowstone for decades as a research scientist, beginning with a dissertation on Ross's Beautygrass, a plant endemic to Yellowstone. Tercek has since developed a specialty in climate projections, and in fact coded a program to aggregate climate-related information from various environmental monitors in the park, to aid park-specific modeling. The program is now used by a number of other national parks. We had asked Tercek to brief the team on climate science at Yellowstone. Seeing the scope of the lab's interests, he asked if he could also say something personal about how he understood the implications of those changes. Welcomed to do so, Tercek quoted Emerson, Thoreau, Muir, and the subsequent American wilderness tradition to explain what this landscape means to him. Long periods alone in backcountry forest are central to his understanding of himself and to his coping with existence. "I'm not religious," he said, "but I sense a presence here; in the deep wilderness. I feel known and healed; my ego is overcome there."

But now the healing power of backcountry forest seems imperiled. The highest correlation in North America between climate change and increased fire intensity lies within Greater Yellowstone Ecosystem. The park-specific data his program has aggregated, correlated with the IPCC warming scenario pathway representing current emissions, projects that within a few decades, 100 per cent of the park will burn every ten years (Tercek 2019). Yellowstone is likely to lose all of its forest. Tercek lives with the anxiety of loss, to the extent, he says, that it makes him feel physically sick, nauseous. He hikes into the backcountry forest now and, instead of being overcome and reoriented, he experiences a kind of moral vertigo.

A conventional religious tradition is not required to sacralize a place (Howe 2016). The several streams of settler culture that came together to imagine Yellowstone National Park as a non-religious 
spiritual retreat included the transcendentalisms of Emerson and Thoreau and the Romantic sublime of Muir. The merging of those streams into the American wilderness tradition, opened what Jedediah Purdy has described as "secular pilgrimage, a seasonal passage into landscape whose sacral quality lay in its power to bring on the epiphanies Thoreau urged" (Purdy 2015, pp. 127-28). Yellowstone became a template for national nature parks as secular sanctuaries set aside for elevating purposes of human enjoyment. If not everyone entered with spiritual purposes, secular pilgrimage names the practice that recognized and legitimated the park's highest function: to draw one into a renewing encounter with nature. Yet that sacral quality, that power to elicit suspensions of self, now seems imperiled to Tercek and to others who share the tradition of wilderness parks as places of spiritual encounter. They seem to be experiencing a shift from Yellowstone as a refuge from social ills to instead a crucible of them. If so, that would represent another historic reversal in the settler American experience of wilderness. What will happen to the environmental norms and senses of self that it carries?

Part of the trouble with wilderness, of course, is that it conceals its sacral quality in naturalizing discourse, as if wilderness were a natural kind, the park boundary tracing an empirical geological feature. The suspensions of self in this secular pilgrimage have historically depended on regarding seized territory as uninhabited and primeval. I will return to that expulsive dynamic with sanctuaries. For now my point is just that supposedly secular sanctuaries are as eligible for critical attention as the conventionally marked sort in the Buddhist kingdom of Bhutan or the "Holy Lands" surrounding the Jordan River.

Any border creates cultural and political tensions; the borders of sacred places can be especially charged because they compel reflection on what is meaningful enough to suspend ordinary life. By suspending at its threshold the ordinary regime of values that shape life outside it, they stimulate reflection on the sources of goodness and meaning both within and without the boundaries. That is why, writes sociologist Justin Farrell, minor management issues at Yellowstone so quickly erupt into deep conflicts and continent-wide debates: "Because Yellowstone is such a symbolically important and even sacred place for so many Americans," he writes, "it serves as an emotional lightning rod that reveals in stark terms our nation's moral boundaries around nature" (Farrell 2015, p. 30). How its boundary is managed-for bison and wolves, tourists and snowmobiles—represents for many what is sacred, good, or meaningful.

What then happens to those ideas of the sacred and the conflicts between them as planetary warming moves ecological thresholds the boundary is meant to protect? When the bison seek to migrate out as invasive grasses move in, as snow retreats and fires grow? As visitor numbers rise with increased desire for contact with what the boundaries around Yellowstone represent? Responses to those questions will reshape American ideas of nature and certain practices of self-formation.

As Tercek's comportment disclosed, those responses may show up in affect as much as in word or text. Pressures on Yellowstone's threshold may alter long-lasting moods, circuits of feeling, or patterns of sensory embodiment. The sort of religion that makes Yellowstone's boundary into a culturally significant threshold is not just about formal beliefs about nature or the sacred, but especially "about the way things feel," as Donovan Schaefer argues; "the way our bodies are guided through thickly textured, magnetized worlds" (Schaefer 2015, p. 4). Schaefer calls for research on religion to seek "the way that bodies are shot through with the affects evoked by the world" (p. 106), as a mammalian evolutionary affordance shaped by material networks of culture and power. For Sanctuary Lab, that entailed studying the networks of thought and practice that have shaped ways of interacting with national parks generally and Yellowstone particularly. It also entailed crossing the boundary ourselves, observant of our own experiences and attentive to how those deeply shaped by the threshold seemed to experience it.

\section{Sanctuary as Laboratory}

Sanctuary Lab takes a keyword in Religious Studies, the sacred, to open a line of inquiry into how cultural processes are interacting with rapid environmental changes. "Sacred" is of course a contested 
concept, deployed in service of various theories of religion. Skirting disciplinary arguments over whether or what is religion, Sanctuary Lab uses the term to convene post-disciplinary collaborative inquiry into places that seem invested with special significance by contingent alliances of imagination and power. We do not suppose that sanctuaries are necessary geographical designations any more than we suppose that they are natural geological features; they are imagined by human communities and made by political acts.

The Sacred Natural Sites initiative, a decades-running global effort supported by International Union for the Conservation of Nature (IUCN), describes places "'set aside' for purposes spiritual and religious" (Verschuuren et al. 2012, p. 1). What are those kinds of purposes? Sometimes they may be those of an historically recognized religion but, as the Yellowstone example shows, sometimes those purposes are perceived as non-religious by people whose sense of self and belonging are deeply shaped by them. I would prefer to say that these places are set aside for the sake of that which vests meaning in some shared sense of everyday life. Indeed, the act of setting aside helps generate a sense of the everyday by distinguishing places through which meanings of everyday life may be uniquely encountered.

"In these places nature and humanity meet," write editors from the IUCN project, "and people's deeper motives and aspirations are expressed through what is called 'the sacred"" (Verschuuren et al. 2012, p. 1). Their phrase, "what is called 'the sacred,'” acknowledges that they employ the term as a provisional bridge concept. It permits comparison of lands made special in many different ways for different purposes, which, for them, then provides a basis for coalition building by communities facing serial threats from global forces. Near the end of his book on countercultural sacred places, Adrian Ivakhiv writes: "sacred places are the physical and geographic anchor points for our psychic and cultural imaginings, the stories we tell about ourselves, the world and the relations between them" (Ivakhiv 2001, p. 239). These geographies are (in some way, for some people) densely knotted with significance.

Convening research in sites regarded as sacred affords unique perspective into how cultural imaginations are interacting with planetary changes. Precisely because a place is densely knotted with significance, standing as an anchor point in some understanding of the world, new global flows and planetary stresses seem likely to send reverberations through the imaginations and stories by which it was set apart. Sacred places thus seem to offer unique vantages into experiences of the Anthropocene. Belden Lane in the opening to his Landscapes of the Sacred writes: "To experience a place as sacred is to participate, knowing or unknowingly, in a whole history of cultural tensions and conflicting claims, even ecological shifts in the terrain itself" (Lane 2001, pp. 3-4). Sanctuary Lab asks how rapid ecological shifts and new global flows affect the experience of these places and the management of their conflicting claims, with what implications for the moral imaginations by which they are made special.

We question, in other words, how the sacralizing processes that led to these places being set apart now interact with Anthropocene relations. Approaching landscapes with that grand mace, "the Anthropocene," our aim is not reductive analysis, to fold the many stories by which people and places are differentiated into an epochal narrative. On the contrary, we seek the particular histories, traditions, and practices through which people are interpreting and negotiating planetary stresses. In academic discourse, the term often names the challenge of imagining unprecedented and conflicting scales of human and nonhuman agencies unfolding in multiple temporalities (Latour 2014; Chakrabarty 2018). One of the liabilities of Anthropocene discourse is that its planetary scope and species-level vocabulary, especially when embedded in a managerial framework, abstracts from the languages, values, and practices through which people experience particular environments. An important role for environmental humanities lies in pluralizing the relations invoked by the term Anthropocene and describing how different conceptions of value and purpose interact with them (Castree 2014).

Nor do we, by working with a term from Religious Studies, wish to reduce multiple ways of knowing and being into a notion of religion bounded off from the secular. On the contrary we 
use "sacred" to mark places of biocultural difference that must be understood by the diverse forms of imagination and power that have made them special. Because these places are made special through particular cultural inheritances and specific cosmological practices, our wager is that we can investigate where and how Anthropocene forces and powers enter particular worlds, and the diversity of experimental futures being made with them.

Used obtusely, those perilous inventions of analysis, "religion" and "Anthropocene," can distort more than they illuminate about what is happening in particular places, relations, and communities. The term "sanctuary" draws on a spatial concept with a long history of marking places as sacred in order to interpret broader powers and to create refuges from their dangers. Observing historical and contemporary movements within which designated sanctuaries create immunity from secular, sovereign authorities, James Chappel in fact proposes sanctuary as a key concept for post-secular study of global religion. By establishing a geographical site from which to resist some simplifying matrix of power, "what the concept of sanctuary does, essentially, is announce that this place shall not be governed by the sovereign" (Chappel 2020, pp. 24-25). These places recombine religion and secularity, political subjectivity and the state, in ways that, by offering refuge from dangers, produce alternative formations of human experience. What happens, then, when the sovereign is entangled with anthropogenic planetary change? How to create possibilities of immunity from climate forcing or accelerated sea-level rise?

Sanctuaries present especially valuable sites for those kinds of inquiry because they are often imagined to offer refuge from change, as places set aside from normal powers or pressures. The traditions by which they are sacralized must then reckon with changes, incorporating them into the meaning of the place, and so may face acute pressure in the face of unprecedented rates of change or exogenous drivers. What happens in these special places, dense with interpretive significance for particular communities, will then shape how those communities imagine and make futures.

Those interpretations need not explicitly acknowledge planetary pressures in the way that Tercek did with climate crisis at Yellowstone. In many contexts, Anthropocene stress on religious interpretation may be more oblique, indirect, and unthematized (Jenkins 2017). Just so, it will still shape how communities make their way with these forces, temporalities, relations, and anxieties.

We thus treat sanctuaries as laboratories of coupled cultural-environmental change. In Moral Laboratories, the anthropologist Cheryl Mattingly uses the term to focus on how families face challenges and shifting conditions by experimenting with what they have inherited. She observes how "small events can serve as experiments in possible futures" (Mattingly 2014, p. 73). Analogously, we listen for how places experiment with their inheritances and especially listen for those moments in which we hear participants in those places experimenting with possible futures. The research theme then is not one of simple threat: sacred places imperiled by Anthropocene forces. Rather, we suppose that sacralization is often part of the process through which cultures make meaning of rapid changes, and thus part of various experiments in possible futures.

\section{Bhutan as Beyul}

Consider Bhutan's self-presentation as a Buddhist sanctuary. Into this land's received tradition as refuge for teachers and treasures of Vajrayana Buddhism the nation now incorporates ecological conservation and also, with Gross National Happiness, an enlightened refuge from excessive capitalism. In high-profile international settings its leaders have announced that the country is carbon negative and, supported by a constitutional mandate to maintain sixty percent forest cover, have pledged to remain carbon negative in perpetuity. Those policies, combined with restrictions on development and tourism, make it a place set apart.

Attractive to patrons and pilgrims, the policies may also help Bhutan negotiate threats of geopolitical pressure and planetary change. As it elevates its sanctuary status, the international regard may help protect it from the fate of Tibet to its North and Sikkim to its West. Temples along key river valleys undertake an elaborate annual ritual to maintain spiritual protection from any calamities that 
might come through the mountain passes, including military invasion. Those same river valleys are vulnerable to devastating glacial lake outburst floods (GLOFs), made more likely by heavier glacial melt. Recent protective rituals respond to fear of invasion and fear of the GLOF.

In the GNH and conservation policies as in the temple rituals, planetary relations seem to occasion another layer of sacralization over previous sediments of sacrality. Over centuries Vajrayana Buddhism in Bhutan has incorporated the various beings and practices of pre-existing landscape relations into a broader sacred geography with nationalist and Buddhist significances. Scholars have sometimes called that process mandalization: incorporating into a geographic mandala local place divinities, thus bringing them and the associated practices into a hierarchical scheme of landscape significance, oriented to an overall narrative of Buddhism taming chthonic forces and superseding archaic practices (Huber 1999). A form of mandalization continues as Bhutan incorporates climate policies and capitalist forces into its sense of sanctuary, taming new suprahuman forces. The process, of course, changes its reception of Buddhism in the process (Branch 2013). Seeing Bhutan allied with science-based conservation and the social psychology of happiness, some now go there to take refuge not in the Buddha exactly, but in the enlightenment of Bhutan. If that seems like tactical sacralization, recruiting global anxieties about climate change and development to make Bhutan a land deserving of regard and patronage, it is part of a long tradition of narrating Bhutan as refuge from exogenous pressures.

Meeting with policy leaders in Thimpu, the capitol city, our faculty from Environmental Science and Law pressed for details: what specific land management policies were being implemented in what ways? Meanwhile faculty from Religious Studies conferred with colleagues from the Royal University of Bhutan who had joined our team on-site: to what extent are Buddhist teachings mobilized to support those policies, through what interpretations? As a team we sought to create an itinerary that would take us into the convergence of those two sets of questions.

Two days switchbacking over mountain passes, negotiating roads cut into the side of steep gorges, brought us to Tharpaling monastery. Perched midway up a mountain dividing the valleys of Chumey and Bumthang, the monastery is associated with the 14th century master Longchen, who systematized five hundred years of previous Buddhist teachings in his work Seven Treasuries. Longchen was abbot of one of the most important monasteries in Tibet but fell afoul of religious politics during Mongol pressure on that land and was forced into exile in Bhutan. Eventually he took refuge in Tharpaling. In preparation for Bhutan our team read a text more influential in regional folk culture, its lines taken up in many stories and songs. Translated into English as Forests of Poetry, Rivers of Composition by the contemporary novelist Ura (2016), the poem describes the valley of Bumthang as a hitherto unknown hidden land (beyul). A term admitting multiple meanings, beyul can indicate a sacred place, a valley difficult to find or reach, a site whose subtle energies can be known only by spiritually adept, a retreat ideal for advance spiritual practice, a vault where Buddhist teachings are preserved as a treasure for future generations, or a sanctuary for those seeking political asylum (Childs 1999; Baker 2006; Allison 2019). Among the polyvalence there seems a basic sense in which the beyul can provide a refuge in times of trouble for those capable of recognizing its reality.

What about the troubles of climate change? As we followed the monastery's caretaking khempo, winding up a steep path from the monastery to a ridge crest where Longchen composed his writing, the law professor pressed the question: does not the sacredness imply that this place is perceived as timeless, untouchable by change? He was captivated by the experience, following a maroon-robed monk up a holy mountain; but he also wondered how this experience related to the policy challenges discussed in the capitol. From the perspective of a holy mountain, he speculated, environmental changes might not even register.

We walked the final several hundred meters through a thicket of wind-snapped prayer flags, attaining a vista to the snowy high mountains at the border with Tibet and over a river silvering through Bumthang Valley below. From here Longchen would have been able to survey the valley he was extolling while looking back to the passes of Tibet, from which he had been exiled. In the poem, Longchen laments that Mongol invasion had diminished the dharma in Tibet but celebrates his 
discovery of Bumthang. This valley is the best place to pursue liberation, he wrote, and the mountain the center of the universe.

How strongly could an exile from Tibet regard this place as cosmic center? Atop the mountain, we revisited the poem, the khempo pointing to the particular landscape features it names and the Tibetanist scholars offering alternative translations in answer to intent questions from the rest of us. By following the path of its composition, the medieval text had come alive for the lab, whose questions sought interpretive keys to the ongoing significance of the cosmology hosted here. A Tibetanist pointed us to a passage describing Mt. Tharpaling at the center of a mandala, the plants of the surrounding land paying homage to it, on precisely the pattern of the eight-petaled lotus unfolding around Mt. Meru. That suggests a quite strong sense, he said: that Longchen held this mountain as center of the cosmos. And "Tharpa-ling," in he noted, means the place of liberation (tharpa the Tibetan translation for moksha). The law professor's query seems apt: what could ever change such a strong place?

Yet near the end of the poem, Longchen worries that Mongol invasion will eventually reach Bumthang and he laments the diminishment of dharma that he anticipates will result here as it did in Tibet. Taking refuge in the beyul at the foot of the sacred mountain at the center of the cosmos, in the very ling of liberation, did not offer protection from change. Longchen offers no rite or practice that may protect the valley from invasion and calamity. Rather it seems that Longchen offers a way of interpreting those threats and changes—even those that will one day overtake it.

Re-reading the text on Tharpaling, the team developed a hypothesis to bring together its questions: the experience of the sacred is precisely how this tradition recognizes and interprets change. Longchen seems to have reinterpreted the dislocative trauma of exile from Tibet, where he had witnessed the way stresses of political invasion corrupted its specialness, by relocating that experience in a mandala centered at Tharpaling. That operation has happened anew in the many incarnations of Longchen since: new stresses are incorporated into a mandala, putting them into cosmic place and thereby taming them-just as Himalayan Buddhism has regularly presented itself as taming unruly demons. The point is not simply to protect oneself against those changes, those demons, but to understand them rightly. That is one way that a tradition can mobilize interpretive authority amidst disquieting change.

That seemed to offer a template to understand how, through a mixture of conventional religious channels, national politics, and new media narrative, Bhutan mandalizes the stresses acting upon it, the threats of invasion-military, economic, ideological, and climatic. Bhutan presents itself as a beyul for the world, a divine hidden valley in which lie liberating treasures for those who approach in right mind and right desire. Pilgrims (of a certain means) are welcome, in hopes that they will not only appreciate the specialness of Bhutan, but will also come to see their own places and lifeways as standing in relation to Bhutan, and in need of it-a place set-apart, maybe as a divine land, or as a forested land, or simply an alternative social path through the Anthropocene.

The ecological and religious future of Bhutan may depend on the extent to which the outside world regards itself in the mandala that Bhutan makes of it, as periphery to its sacred mountain, awaiting the teachings of its hidden valleys, which must be protected. By allowing the mandala from Tharpaling some interpretive authority over our extractive ecologies and excessive capitalisms, seen now as the equivalent of Mongol invaders, it transforms us into pilgrims and patrons. Bhutan's strategy to survive the Anthropocene thus would be a version of the strategy it has pursued for the last five hundred years: present itself as a sanctuary, a place of spiritual treasure, deserving of patronage and protection.

\section{Refuge and Exclusion}

Mandalization seems a benign term. Others see in Bhutan an ethnonationalist Vajrayana fascism that has been sublimating vernacular religious and cultural practices for centuries, recently mobilized to expel those whose religious and cultural practices troubled the idea of a unified Buddhist kingdom. In the early 1990s, around 100,000 people, or about one sixth of the population at the time, were declared non-Bhutanese aliens and were forcibly pushed across the border into India and Nepal, where 
some still live in refugee camps. Some are not Buddhist, some the wrong kind of Buddhist, some speak Nepali instead of Dzongkha. They are all called "Southerners" as a way of designating that their investment in the high-altitude form of ethnic Buddhism regnant in Bhutan is suspect (Hutt 2003). ${ }^{1}$ The processes by which a place is recognized as a beyul also establishes it as territory for a particular community, under the authority of exclusive institutions (Skog 2016).

Sanctuaries generate strong forces of political expulsion and historical sublimation. As they offer asylum for some, they make refugees of others. As they protect one form of interacting with the landscape they may conceal or derogate the history of others (Howe 2016).

Indigenous peoples were continuously interacting with the high plateau for 9000 years before it became Yellowstone National Park, and the Crow People maintain that the land remains rightfully their territory. Yet until the early 2000s, visitors to the Park were told that there was little Native American history there, for the same reason that contemporary tribes did not wish to visit: because they were frightened of its thermal features. Against that laughable assertion research over the past two decades has shown that a number of different peoples travelled long distances along well-known routes, precisely to interact with the unique thermal and geologic features of Yellowstone (Nabakov and Loendorf 2004; MacDonald 2018).

As template of "America's best idea," Yellowstone exported around the world a way of displacing people and erasing their memories in the name of nature. (Those living there do not really belong to this land because they do not properly understand how special it is.) The settler imagination of wilderness, as a special place without people, has often been a genocidal idea: not only legitimating the violent expulsion of indigenous inhabitants, but erasing from the land the histories of its peoples. When those histories are recovered, they may be presented as primeval, implicitly excluding contemporary efforts of indigenous peoples to maintain or re-establish relations with territory.

The landscape currently governed by Palestine, Jordan, and Israel is, most famously among our sites, perceived as a battleground between competing visions of land revealed as holy and promised, as territory for one or another people. For just that reason there is no avoiding it for this project. Ancient literatures written and compiled from this landscape inscribe storied identity into the land differently, with consequences that include crusades, occupation, expulsion, homeland and displacement, finding refuge and being made a refugee. Over the 20th century, Zionism enlisted the landscape by greening deserts, planting forests, destroying olive groves, razing villages, renaming places, erecting settlements, and-perhaps most consequentially—redirecting water. Who may find refuge here is shaped in part by which scriptural lexicons of territory gain power to enlist landscapes into their cosmopolitical projects.

All that is well known. The question now to ask: how do emergent planetary stresses interact with those dynamics of refuge and expulsion? Scholarship on histories of violence and exclusion at these sanctuaries is robust, but research is just beginning to investigate how those forces may be reshaped by Anthropocene relations. For example, if climatic warming accelerates flows of refugees while decreasing flows of water through the Jordan River basin, what implications will that have for how the waters of the Jordan are imagined and managed? "Crossing the Jordan" names a motif of finding sanctuary in multiple (sometimes rivalrous) religious and political registers. Will new stresses on biophysical flows of the river have recursive effects on religious flows?

With the bivalence of refuge and exclusion in mind, it should be clear that those questions do not seek simply to uncover new threats to a special place. Communities may find occasion in new stresses to rework inherited dynamics of refuge and exclusion to create new kinds of sanctuary. Part of the lab's itinerary will be led by those working toward a Jordan River Peace Park, a proposed transboundary political and ecological refuge managed by three states and remembering three streams of religious history. Shared water stress, they think, could lead toward shared affiliations with the river. In that

\footnotetext{
1 The notion to mention this issue is entirely mine and cannot be ascribed to anyone else on the Bhutan research team.
} 
case, climate change as shared relation becomes part of the cultural matrix seeking a different kind of sanctuary—an inclusive, pluralist sacred landscape.

Sanctuaries may also be made to protest or ironize forces of refuge and exclusion. Whenever sanctuary is sought or offered-to humans seeking asylum from violence or refuge from unjust governments, to other animals treated badly by farms or zoos, to other species vulnerable to extinction-it implicitly illuminates some violence. The Sanctuary Movement in the U.S., for example, protests hostile immigration policies by enacting asylum. Offering sanctuary to people facing deportation construes their vulnerability as unjust and the exclusionary policies as illegitimate violence. Especially when sanctuary from deportation is created in religious buildings, offering asylum in a designated sacred place seeks to exclude state power in order to protest state policies of exclusion. Understanding futures of belonging in the North American borderlands therefore needs ways to investigate relations of climate change and human migration in connection with ethnonationalism and border walls. The lab has just begun to formulate questions and itinerary for researching those relations. As so many humans are on the move seeking refuge and asylum of various kinds, what new imaginations of sanctuary are emerging?

\section{Multispecies Sacralization}

Nonhuman creatures are also on the move in an era of climate change and mass extinctions, seeking sanctuary. Our lab wonders: how can we acknowledge and include the ways that nonhuman flows and other species participate in processes of sacralization? Describing the lab's conception of sanctuaries (in Section 2 above) I followed a constructivist line, broadly in line with the legacy of Emile Durkheim, in which sacralization expresses social form. That approach permits us to investigate how sacred places are produced from human imaginations. Yet it also seems incomplete, failing to account for the way certain lands seem to lure human imaginations toward ascribing specialness. They may, in a sense, recruit the sanctuary designation.

High mountains, for example, have long seemed to set their own thresholds, to mark a division of worlds. Cultures have responded to them in various ways: in fear, wonder, veneration, and divinization; through rituals of access, prohibitions of entrance, and making prayer retreats on them; by experiencing the mountain as person, or divinity, or as lair of the demonic, or as arena of the sublime. None of those responses are necessary consequences of the tectonic friction that wrinkled a fold of Earth's crust skyward. Yet neither do they seem arbitrary social projections onto inert space; they are responses.

Imagining a landscape, argues anthropologist Ingold (2011), entails participating in the landscape in some way. It is not an event that happens entirely inside the human brain; it is a relational activity, shaped by the contours and creatures of a place as well as by embodied perception and cultural ideas. Yellowstone has both high mountains and rare geothermal features. Its geological character has for millennia spurred a question in humans: what is the etiquette of relation here? While sanctuaries are not natural kinds, landscapes may enlist human propensities to sacralize. In that sense, the mountains and geysers, American Bison and Grey Wolf, collaborate in the cultural construal of a place as special. They entice sacralizing minds and participate in the social processes by which a place is set apart as sacred.

Our lab therefore asks which nonhumans seem to be stimulating sacralization or taking advantage of affordances created by ascriptions of sacredness. In line with interventions from the field of Multispecies Studies, which asks scholars in humanities and social sciences to work beyond humanist premises to understand how worlds are constituted with diverse forms of life, Sanctuary Lab attends to the ways sacred places are made from the interaction of multiple species participating together to realize particular possibilities of a certain land (van Dooren et al. 2016). In supplement to Durkheim's account of society, it is not only humans who do religious work.

The Hula Valley in Northern Israel has become a key stop-over for birds migrating between Africa and Eurasia. A marshy wetland drained by the Jewish National Fund in the midcentury Zionist 
program of landscape modernization, part of it accidentally reflooded in the late 20th century, and exhausted birds quickly found and claimed it. The National Fund protected part of the flooded areas as a sanctuary, which is now globally famous among birders, many of whom make their own kind of pilgrimage there. You could say that Zionism enlists the birds, but maybe the birds have also enlisted Zionism. They are, for now, collaborators in sacralizing.

The birds follow a flyway that traces the rift valley, from the highland headwaters down the Jordan River over the Dead Sea to the Red Sea, taking advantage of the habitats variously protected by religious designations, by militarized security zones, and by ecological reserves. Our lab's itinerary will follow that flyway, traversing this densely sacralized, bitterly contested landscape along a path made by tectonics, marked by water, reproduced by birds seeking refuge. That line holds religious histories and human politics with geological histories and nonhuman projects, affording the lab a way into the entanglement of particular religious futures with particular fates of nonhuman life, coupled together along uncertain, imperiled flightways.

Refugia are areas where special environmental circumstances have enabled a species to survive after extinction in surrounding areas. (For example, the Yellowstone hot springs are refugia for forms of life that were widespread before the cataclysmic change to an oxygen-rich atmosphere.) Tsing (2017) employs the term more broadly, to refer to conditions that provide haven for biocultural processes and multispecies relations from the plantation simplification and destruction that she takes as hallmark of the Anthropocene. Refugia are critical for livable futures, she writes, for from them may resurge the diversity of multispecies arrangements on which valued human ways of life depend.

Consider sanctuaries as biocultural refugia in that sense. Sacred places often protect some unconventional set of multispecies relations, even when they are not explicit ecological reserves. At least, they are usually set aside from plantation principles of simplification, extraction, and indifferent biological substitution. For that reason, places marked and protected as sacred may have a role to play in resilience and resurgence. Because they offer haven to a multiplicity of biocultural arrangements, they protect multispecies possibilities from extinction. That is one reason for the Sacred Natural Sites initiative of the IUCN: "the sacred" marks havens of biocultural diversity.

In Anthropocene conditions sanctuaries thus may take on new functions of refuge. Think of the Anthropocene not as an enduring planetary condition, writes Donna Haraway, but rather as a boundary, a discontinuity marking the transition between epochs (Haraway 2016, p. 100). Sanctuaries can offer haven both to multispecies relations being extinguished in the Anthropocene and to imaginations being excluded from it. For making ways through the Anthropocene discontinuity perhaps we need sanctuaries to harbor as many possibilities for biocultural resurgence and replenishment as there are sacred stories.

Black-Necked Crane migrates each winter to Bhutan's Phobjika Valley from habitats in Tibet and other places in China. Tradition holds that when they first arrive for the year, they circle (clockwise of course) the temple complex overlooking the valley, before settling in the wide plains. Farmers expect their arrival just after harvest, the cranes and humans seeming to time their provisioning to one another. When it appeared that numbers of Black-Necked Crane were decreasing, the king declared that Phobjika should be managed as habitat for Black-Necked Crane, due to its special relationship with Bhutan. Now the valley plains, rare in this land of narrow gorges and therefore under development pressure for farming and tourism, must maintain winter feeding grounds for Black-Necked Crane.

That action seems to have set in motion cultural processes that elevate Black-Necked Crane's status. While cranes have generally been regarded as admirable creatures in Himalayan Buddhism, regularly appearing in story and art, until recently the bird did not enjoy special political protection. Now the strong conservation policies in Phobjika seem to stimulate religious veneration and incorporation into the story of Bhutan as beyul. Every mention of the bird is sure to note that by migrating between Tibet and Bhutan, Black-Necked Crane keeps alive the connection between these sacred lands. In fact, a painting hanging in the Royal Society for the Protection of Nature in Thimpu depicts flying Black-necked Cranes connecting the most important sites of Tibet and Bhutan. As development in 
China invades habitat of the birds, they find sanctuary in Phobjika-repeating a centuries-old pattern. In the sacralization of Black-Necked Crane, the old/new narrative of Bhutan as beyul is told. At the monastery above Phobjika Valley, Black-Necked Crane has recently been inserted into the murals depicting the masters and incarnations around which the narrative of this land is shaped. Meanwhile, the long-legged creatures, regal in posture, walk the Phobjika fields and pastures in confidence that this is their refuge.

Early one morning I awoke in the dark to go to the valley floor with the music professor. He wanted to record the dawn clamor of the cranes. We set up the microphones atop a layer of fresh snow and then waited in the moon-lit fog that lay thick over the warm-watered valley bottom. Dogs skirted around us, mutually wary, loping with territorial purpose and tracking barks from the farmhouse settlements, their own sociality evident. We waited. Snow-muffled steps of herds beginning to think about moving. The silhouette of cows, shaggy horses, and yak, lugubrious in the cold. We waited. Then, still before a hint of dawn, Oriental Skylark began to call, the dispersal of their high-pitched song testifying to great numbers spread throughout the grasses. We waited. Finally, as mountains to the East began to be outlined by the first flush of light, a crane called. It was from a group far up the valley, near the base of the temple complex. Individuals in a group down-valley, nearer to us, answered. A few family groups of three seemed to switch places, wing-beating in opposite directions. As the day brightened the two groups set to full clamor, their high bugling sound ringing off the mountainsides, dispelling the fog. Little Grebe awoke and began patrolling up and down the river. Ruddy Shelduck set aloft due south, away from the hilltop temple complex, now emerging from the crane-dispelled fog.

By waiting upon Black-Necked Crane we encountered a complex assemblage of biosocial relations finding refuge in crane clamor. In order to protect their habitat, no construction, tillage farming, or water channelization is permitted in the valley center. Within that protection, other bird species also find refuge. So do the mixed herds of free-ranging cattle and the broader ecosocial system of pastoral livelihood from a commons. So do the absorbent soils beneath the marsh grasses that (our environmental scientist taught us to see) take in the monsoon rains like a sponge and release them slowly. So do the quasi-feral dogs, moving across those worlds and policing them for their own ends.

In the land of the sacred Black-Necked Crane, domestic, feral, wild, economic, and religious forms of life negotiate a shared common. Phobjika as refugia offers not only Black-Necked Crane a chance to survive, but a set of landscape relations the possibility to make their way together through the harrowing and replenish the possibilities beyond it.

\section{Arts of Attentiveness}

Why spend such time, money, and carbon to assemble the lab in each place? Following Ingold's point that perception of landscapes arises from some form of participating in them, Lane argues for a phenomenological method, in which the researcher's experience has an important role in understanding sacred places. To an extent, Sanctuary Lab follows the supposition that inquiry is enhanced by the collective experience of participating in the landscape under study. This essay's peculiar style highlights the contributive role of experience. But Lane also shows the liabilities of thinking from experience when he writes: "one's actual embodied experience in encountering a place perceived as sacred is crucial, then, to the sense of magic or awe one finally attributes to it" (Lane 2001, p. 53). That could mislead, as if the researcher needs to feel the magic historically ascribed to the place. Worse, it could invite researchers to treat their own experiences as reliable, even superior, knowledge about the specialness of a place. Especially when the majority of the team shares cultural background and material privilege, and when their engagements with a place are short, reflecting from experience, as I have done throughout this essay, runs high risks of perspectival distortion and ethnocentric imposition.

Precisely in order to stimulate critical reflection on the frames and practices through which researchers experience a place, Sanctuary Lab includes arts-based practices of attentiveness as part of its method. It is an important reason why each team includes a faculty member from the arts. In places dense with cultural signification, so trodden by paths of pilgrims and tourists that it is hard 
to experience anything but their overdetermination, exercises of embodied attentiveness offer a way of participating in the landscape, creating an experience from which to ask anew why the place has enticed sacralizing minds from many worlds for thousands of years. They offer a way to walk at once along and askance from the heaviest paths of sacralizing traditions, allowing researchers to reflect on those cultural pathways while also opening themselves to experience the living landscape that has been enlisted into those pathways. The intentionality of an arts exercise compels critical reflection on the mediation of experience.

Mammoth Hot Springs, a short walk from parks headquarters along a road with stores and cafes, is the background to a million selfies. For just that reason, I did not want to go there. Most people come to Yellowstone not as pilgrims to sacred wilderness, of course, but just to gaze at the wonders. The Park was in fact long marketed as "wonderland," a place for the affluent to come see fabulous curiosities. Yet it was here, on the elaborate wooden walkways built to manage the human traffic, that the music professor chose to set up a listening station: a hydrophone dropped into water bubbling from a thermal vent, channeled with an omnidirectional mic to hear variegated surface flows. Skeptical of the venue, the elaborate equipment, and the entire exercise, I slipped on the headphones out of politeness. And then, in spite of my attitude, I found myself confronted with the live presence of an unfinished volcanic event. The steaming, bubbling sounds moving through my mind were made by temporalities and powers greater than the anthropogenic forcings stressing the forest cover above, certainly greater than the colonial forces that drew the boundaries and erected the walkways. In the midst of over-tourist wonderland, I was caught up in wonder at the presences that have attracted sacralizing minds for millennia.

Leaders in Multispecies Studies have called for researchers to create "arts of attentiveness" as a first step toward scholarship that can carry inquiry beyond observational noticing "into the cultivation of skills for both paying attention to others and meaningfully responding" (van Dooren et al. 2016, p. 17). Their hypothesis is that better, integrated forms of knowing rapidly changing worlds are more likely to arise from immersion within their liveliness. Explaining his own phenomenological approach to sacred sites, Ivakhiv suggests bracketing the conventional notion of landscape as inertly objective and adopting a functionally animist perspective, as a way into inquiry from reciprocal relation with a place (Ivakhiv 2001, p. 14). Animist or not, the mode of inquiry involves a normative decision of how to acknowledge and interact with the relations of a place. Deborah Bird Rose and Thomas van Dooren call for multispecies attentiveness as a matter of research ethics: "we understand ethics as an openness to others in the material reality of their own lives ... with their multitude of interdependencies and precarities, their great range of calls, their care and their abundance along with their suffering and their grief" (Rose and van Dooren 2017, p. 124). By listening to the life of Phobjika, we opened our investigation to the many projects of other species who find refuge in the calls of Black-Necked Crane. More happens in that moment than unusual acquisition of data about a contemporary sacralization process; including arts of attentiveness within research protocols invites lab members to acknowledge our research as a multispecies practice, a form of interaction with nonhuman relations.

Before we left Mammoth, the music professor handed out wind instruments made from stones and some simple percussion items, and invited us to play something back for the thermal springs, as a gesture of acknowledgement and gratitude. Uncomfortably participating in this gesture of reciprocity compelled us to reflect on how academics ordinarily come into a place and the unstated ontological terms by which we propose to interact with it. As a practice of art, it was not quite religious, yet as an offering of respect and relation, it was not entirely secular either. The exercise compelled attention to contingent premises of embodied experience in the place-our own, our local experts', those of predecessors and of future generations.

Even while pursuing historical perspective and critical knowledge about these places, we thus also seek affect-oriented pathways for attending to the stresses that are making futures. Arts of attentiveness allow researchers to connect disciplinary forms of inquiry with an often-avoided question of basic relations: whose relations convene here and what kind of claims can they make? Acknowledging 
the question and the conflicts it represents can create an ontological opening, a consideration of arrangements alternative to those currently or even historically dominant. Sometimes in such practices, the art of inquiry can become itself an offering of sanctuary: in the posture of listening, a way of letting imagination attend to the biocultural pasts and possibilities of the place.

\section{Conclusions}

How are Anthropocene relations bearing on religion, and how are religious processes shaping Anthropocene futures? This essay has shared hypotheses and collaborative research practices that have emerged from Sanctuary Lab in hopes of advancing discussion of methods for investigating that lead question. The six sections of the paper have generated six suggestions: (1) the cultural tensions produced by thresholds of sacred space may be intensified by new pressures on boundaries, which may show up in affective experience; (2) sanctuaries can be treated as laboratories for studying how particular cultural processes are interacting with global flows and planetary stresses; (3) ecosocial futures are forged as communities redeploy inherited ways of interpreting new threats and creating refuge from them; (4) insofar as sanctuaries generate forces of expulsion and political violence, planetary stresses interact with those dynamics as well, in uncertain and indeterminate directions; (5) nonhuman species, flows, lands, and forces participate in sacralization processes; (6) arts-based practices of attentiveness can introduce landscape participation into the mode of inquiry, while also driving critical reflection on mediations of experience.

The two key terms of our lead question faded in importance. Those perilous inventions of analysis, "religion" and "Anthropocene," can distort more than they illuminate about what is happening in particular places, relations, and communities. I have treated them as proxies for two knots of critical debate that, when brought together, may advance understanding of how cultural processes are interacting with global flows and planetary stresses in places designated as sanctuary from sovereign powers and exogenous dangers. I have tried to illustrate how "sanctuary" can organize research with potential to contribute toward transdisciplinary studies of coupled human and environmental change. A central challenge for environmental change research is integrating different scales and tempos of change, finding ways to illuminate the frictions and feedbacks among them. The lab has not yet created a fully transdisciplinary approach, I should be clear. A particular challenge remains how to better incorporate the sciences and develop research that helpfully informs environmental change science (Castree 2014; Palsson et al. 2013).

Finally, I note that feedback from researchers in Sanctuary Lab as well as from early public audiences suggests that interest in its experiment goes beyond advancing academic capacities of investigation. Participants and the public seem drawn to it as a way to search for resilience, looking to the unusual research practices for a signal of how to dwell amidst the frictions and temporalities of this discontinuity. Research outputs from the lab thus seek to engage publics and scholars in a variety of formats: in addition to conventional scholarly articles, we are creating podcasts, short documentary video, musical composition and performance, and creative nonfiction. We have discovered that-especially when they involve researchers collaborating across borders and disciplines-practices of attending, questioning, and sharing can themselves make a kind of refuge.

Funding: This research received no external funding. Sanctuary Lab was initiated with pilot funding from the University of Virginia.

Acknowledgments: While this essay cannot be taken to reflect the views of my collaborators, it is indebted to everyone in Sanctuary Lab, especially Martien Halvorson-Taylor and Kurtis Schaeffer. Encouragement to write from this project began in a Luce Foundation working group on the Anthropocene convened at Duke University by Jedediah Purdy and Norman Wirzba, and was further shaped by a conference on "Vulnerability in the Anthropocene," convened by Matthew Wickman and George Handley at Brigham Young University. I am grateful for the feedback from many colleagues in both settings, and to two anonymous reviewers from this journal.

Conflicts of Interest: Author declares no conflict of interest. 


\section{References}

Allison, Elizabeth. 2019. Deity Citadels: Sacred Sites of Biocultural Resistance \& Resilience in Bhutan. Religions 10: 268-85.

Baker, Ian. 2006. The Heart of the World. New York: Penguin.

Branch, Matt. 2013. Climate change projects in the land of gross national happiness: Does religion play a role in environmental policy in Bhutan? In How the World's Religions Are Responding to Climate Change. Edited by Robin Globus Veldman, Andrew Szasz and Randolph Haluza-DeLay. New York: Routledge.

Castree, Noel. 2014. The Anthropocene and the Environmental Humanities: Extending the Conversation. Environmental Humanities 5: 233-60. [CrossRef]

Chakrabarty, Dipesh. 2018. Anthropocene time. History and Theory 57: 5-32. [CrossRef]

Chappel, James. 2020. The Logic of Sanctuary: Towards a New Spatial Metaphor for the Study of Global Religion. Journal of the American Academy of Religion 88: 15-34. [CrossRef]

Childs, Geoff. 1999. Refuge and revitalization: Hidden Himalayan sanctuaries (Sbas-yul) and the preservation of Tibet's Imperial Lineage. Acta Orientalia 60: 126-58.

Deane-Drummond, Celia, Sigurd Bergmann, and Markus Vogt. 2017. Religion in the Anthropocene. Eugene: Cascade.

Farrell, Justin. 2015. The Battle for Yellowstone: Morality and the Sacred Roots of Environmental Conflict. Princeton: Princeton University Press.

Haberman, ed. n.d. Understanding Climate Change through Religious Life-Worlds. Bloomington: Indiana University Press.

Haraway, Donna. 2016. Staying with the Trouble: Making Kin in the Chthulucene. Durham: Duke University Press.

Howe, Nicolas. 2016. Landscapes of the Secular: Law, Religion, and American Sacred Space. Chicago: University of Chicago Press.

Huber, Toni. 1999. The Cult of Pure Crystal Mountain: Popular Pilgrimage and Visionary Landscape in Southeast Tibet. New York: Oxford University Press.

Hutt, Michael. 2003. Unbecoming Citizens: Culture, Nationhood, and the Flight of Refugees from Bhutan. New Delhi: Oxford University Press.

Ingold, Tim. 2011. The Perception of the Environment: Essays on Livelihood, Dwelling, and Skill. New York: Routledge Press.

Ivakhiv, Adrian. 2001. Claiming Sacred Ground: Pilgrims and Politics at Glastonbury and Sedona. Bloomington: Indiana University Press.

Jenkins, Willis. 2017. Feasts of the Anthropocene: Beyond Climate Change as Special Object in the Study of Religion. South Atlantic Quarterly 116: 69-81. [CrossRef]

Jenkins, Willis, Evan Berry, and Luke Beck Kreider. 2018. Religion and Climate Change. Annual Review of Environment and Resources 43: 85-108. [CrossRef]

Lane, Belden. 2001. Landscapes of the Sacred: Geography and Narrative in American Spirituality, 2nd ed. Baltimore: Johns Hopkins University Press.

Latour, Bruno. 2014. Agency at the Time of the Anthropocene. New Literary History 45: 1-18. [CrossRef]

Latour, Bruno. 2017. Facing Gaia: Eight Lectures on the New Climatic Regime. Cambridge: Polity Press.

MacDonald, Douglas. 2018. Before Yellowstone: Native American Archaeology in the National Park. Seattle: University of Washington Press.

Mattingly, Cheryl. 2014. Moral Laboratories: Family Peril and the Struggle for a Good Life. Berkeley: University of California Press.

Nabakov, Peter, and Lawrence Loendorf. 2004. Restoring a Presence: American Indians and Yellowstone National Park. Norman: University of Oklahoma Press. 
Palsson, Gisli, Bronislaw Szerszynski, Sverker Sörlin, John Marks, Bernard Avril, Carole Crumley, Heide Hackmann, Poul Holm, John Ingram, Alan Kirman, and et al. 2013. Reconceptualizing the 'Anthropos' in the Anthropocene: Integrating the social sciences and humanities in global environmental change research. Environmental Science \& Policy 28: 3-13.

Purdy, Jedediah. 2015. After Nature: A Politics for the Anthropocene. Cambridge: Harvard University Press.

Rose, Deborah Bird, and Thomas van Dooren. 2017. Encountering a More-Than-Human World: Ethos and the Arts of Witness. In The Routledge Companion to the Environmental Humanities. Edited by Ursula K. Heise, Jon Christensen and Michelle Niemann. New York: Routledge, pp. 120-28.

Schaefer, Donovan. 2015. Religious Affects: Animality, Evolution, and Power. Durham: Duke University Press.

Sideris, Lisa H. 2017. Consecrating Science: Wonder, Knowledge, and the Natural World. Berkeley: University of California Press.

Skog, Lindsay. 2016. Khumbi yullha and the Beyul: Sacred Space and the Cultural Politics of Religion in Khumbu, Nepal. Annals of the American Association of Geographers 107: 546-54. [CrossRef]

Szerszynski, Bronislaw. 2017a. Gods of the Anthropocene: Geo-spiritual formations in the earth's new epoch. Theory, Culture, Society 34: 253-75. [CrossRef]

Szerszynski, Bronislaw. 2017b. From the Anthropocene Epoch to a New Axial Age. In Religion in the Anthropocene. Edited by Celia Deane-Drummond, Sigurd Bergmann and Markus Vogt. Eugene: Wipf \& Stock, pp. 35-52.

Tercek, Mike. 2019. Nowcasting and Forecasting Fire Severity in Yellowstone; Washington, DC: National Park Service. Available online: https://www.nps.gov/articles/nowcasting-forecasting-fire-severity-in-yellowstone.htm (accessed on 5 March 2020).

Tsing, Anna. 2017. A Threat to Holocene Resurgence Is a Threat to Livability. In The Anthropology of Sustainability. Edited by Marc Brightman and Jerome Lewis. New York: Palgrave Macmillan.

Ura, Dasho Karma. 2016. Longchen's Forests of Poetry and Rivers of Composition in Bhutan. Thimpu: The Centre for Bhutan Studies and GNH Research.

van Dooren, Thom, Eben Kirksey, and Ursula Münster. 2016. Multispecies Studies: Cultivating Arts of Attentiveness. Environmental Humanities 8: 1-23. [CrossRef]

Veldman, Robin, Andrew Szasz, and Randolph Haluza-Delay, eds. 2014. How the World's Religions are Responding to Climate Change. New York: Routledge.

Verschuuren, Bas, Jeffrey McNeely, Gonzalo Oviedo, and Robert Wild. 2012. Introduction: Sacred Natural Sites, the Foundation of Conservation. In Sacred Natural Sites: Conserving Nature and Culture. Edited by Bas Verschuuren, Jeffrey A. McNeely, Gonzalo Oviedo and Robert Wild. New York: Routledge.

(C) 2020 by the author. Licensee MDPI, Basel, Switzerland. This article is an open access article distributed under the terms and conditions of the Creative Commons Attribution (CC BY) license (http://creativecommons.org/licenses/by/4.0/). 

MDPI

St. Alban-Anlage 66

4052 Basel

Switzerland

Tel. +41616837734

Fax +41 613028918

www.mdpi.com

Religions Editorial Office

E-mail: religions@mdpi.com www.mdpi.com/journal/religions

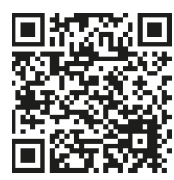



MDPI

St. Alban-Anlage 66

4052 Basel

Switzerland

Tel: +41 616837734

Fax: +41 613028918

www.mdpi.com 